Danmarks geologiske Undersøgelse.

I. Række. Nr. 12.

\title{
Beskrivelse \\ til \\ Geologisk Kort over Danmark \\ (i Maalestok 1:100,000).
}

\section{Kortbladet Skamlingsbanke}

ved

A. Jessen.

Med 1 Kort og Résumé en français.

Kjøbenhavn.

I Kommission hos C. A. Reitzel.

Fr. Bagges Kgl. Hof-Bogtrykkeri.

1907.

Pris : $2 \mathrm{Kr}$. 


\title{
Fortegnelse over Danmarks geologiske Undersøgelses Skrifter.
}

\author{
I. Række. \\ Beskrivelser til Geologisk Kort over Danmark i Maalestok 1:100000.
}

Nr. 1. K. Røndam. Kortbladene Helsingør og Hillerød.

$1893 \ldots \ldots \ldots \ldots \ldots \ldots \ldots \ldots \ldots \ldots$ Pris $2,00 \mathrm{Kr}$.

- 2. N. V. Ussing og Victor Madsen. Kortbladet

Hindsholm. $1897 \ldots \ldots \ldots \ldots \ldots \ldots \ldots \ldots \ldots$. $2,00-$

- 3. A. Jessen. Kortbladene Skagen, Hirshals, Frederikshavn, Hjøring og Løkken. 1899 .... - 6,00 -

- 4. A. Jessen. Kortbladene Læsø og Anholt. 1897. - 1,50 -

- 5. Victor Madsen. Kortbladet Samsø. 1897.... - 1,50 -

- 6. K. Røвdaм. Kortbladene Kjøbenhavn og Roskilde. $1899 \ldots \ldots \ldots \ldots \ldots \ldots \ldots \ldots \ldots-4,00-$

- 7. Victor Madsen. Kortbladet Bogense. 1900... - 2,00 -

- 8. K. Rørdam og V. Milthers. Kortbladene Sejrø, Nykjøbing, Kalundborg og Holbæk. 1900 - 5,00 -

- 9. Victor Madsen. Kortbladet Nyborg. 1902 ... - 4,50 -

- 10. A. Jessen. Kortbladene Aalborg og Nibe (nordlige Del). $1905 \ldots \ldots \ldots \ldots \ldots \ldots \ldots \ldots \ldots-4,50 \quad{ }^{\circ}$

- 12. A. Jessen. Kortbladet Skamlingsbanke .... - $2,00-$

\section{Afhandlinger om specielle, videnskabelige og praktiske Emner.}

Nr. 1. K. RøRDAm. Undersøgelse af mesozoiske Lerarter

og Kaolin paa Bornholm i geologisk og teknisk Henseende. $1890 \ldots \ldots \ldots \ldots$. Pris $1,25 \mathrm{Kr}$. 
Danmarks geologiske Undersøgelse.

I. Række. Nr. 12.

Beskrivelse

til

\section{Geologisk Kort over Danmark}

(i Maalestok 1:100,000).

\section{Kortbladet Skamlingsbanke}

ved

A. Jessen.

Med 1 Kort og Résumé en français.

Kjøbenhavn.

I Kommission hos C. A. Reitzel.

Fr. Bagges Kgl. Hof-Bogtrykkeri.

1907. 


\section{Indhold.}

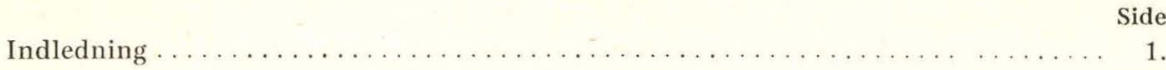

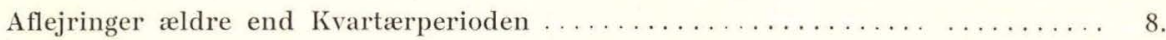

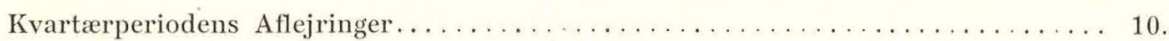

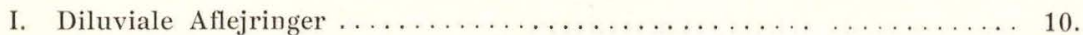

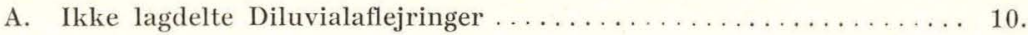

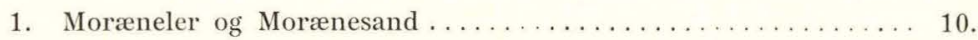

2. Morænegrus og stenet Sand .................. 32 .

3. De løse Blokke........................... 35 .

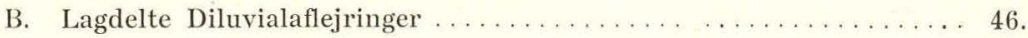

1. Lagdelt Diluvialler ....................... 46.

2. Lagdelt Diluvialsand ....................... 49.

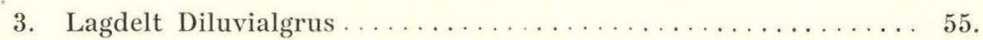

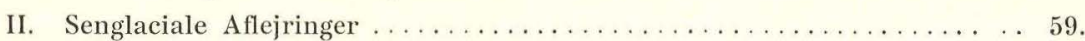

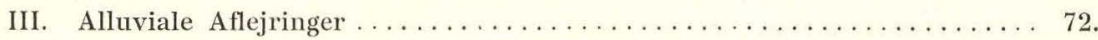

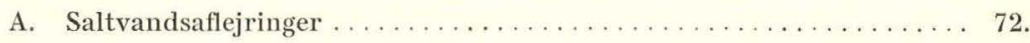

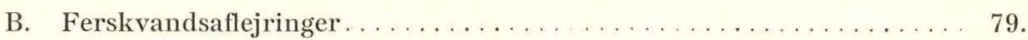

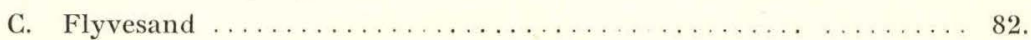

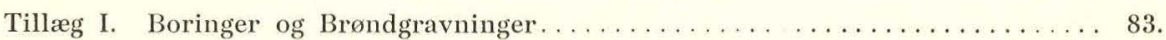

Tillæg II. Mekaniske Analyser af Jordarter $\ldots \ldots \ldots \ldots \ldots \ldots \ldots \ldots \ldots \ldots$.

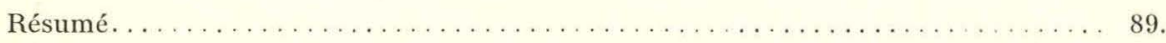




\section{Indledning.}

Kortbladet "Skamlingsbanke" undersøgtes i Aarene 19011903 af Forfatteren med Assistance af Mag. sc. V. Nordmann; en kort Revision foretoges i 1905 af Forfatteren.

Kortbladsomraadet omfatter Landstrækninger paa begge Sider af Lillebelt, nemlig paa Fyn: den vestlige Del af Vends Herred samt en ringe Del af Baag Herred, begge i Odense Amt, og i Jydland: største Delen af Nørre Tyrstrup Herred i Veile Amt og et lille Parti af Anst Herred, Ribe Amt.

De orografiske Forhold vise sig her - som overalt i Danmark - at staa i nøje Forbindelse med Jordbundens Beskaffenhed og den Maade, hvorpaa de øverste Jordlag ere aflejrede.

Iøjnefaldende ved den fynske Del af Kortbladsomraadet er den stærkt bugtede Kystlinie og de mod Vest og Nordvest udskydende Halvøer. Tænker man sig de nu inddæmmede og delvis tørlagte Arealer samt de i Bunden af Vigene liggende, lave Engdrag dækkede af Vand, vil man faa et endnu tydeligere Indtryk af Terrainformerne med den øst-vestlige og sydøst-nordvestlige Udstrækning af Højdedrag og mellemliggende Lavninger.

Nord for den ret stejle Kyst, der strækker sig i SØ-NV forbi Gamborg By, er Landet jæunt bølget med Højder paa $15-20 \mathrm{~m}$. Ved det inddæmmede, men kun delvis tørlagte Fjordareal indenfor Svinø og den brede Dal omkring Viby Møllebæk adskilles dette Højland fra et Syd derfor liggende Højdedrag, der fra Ubby og Rodlund strækker sig mod VNV til Rodlund Skov, og som fortsættes i den nu landfaste Svinø, hvis enkelte, smalle Bakkerygge alle have samme Retning som Hovedstrøget. Højlandet omkring Ubby naaer op til omtrent $30 \mathrm{~m}$. o. H. og falder temmelig brat af mod Syd; paa Svinø naa Bakkerne kun lidet over $10 \mathrm{~m}$. o. $\mathrm{H}$. 
Medens Farvandet mellem Gamborg og Svinø er meget lavt og fladt, træffer man Syd og Vest derfor, i den lange, smalle Gamborg Fjord, en Dybde paa 6-14 m. Ogsaa Gamborg Fjord, der i tidligere Tid var meget bekendt for den betydelige Marsvinfangst, som dreves her, har Retningen NV - SØ. Mod Nordvest fortsættes Fjorden i Fænø Sund, og mod Sydøst har den tidligere strakt sig ind til Middelfart-Assens Landevejen; den inderste Del af Fjorden, Fyns Vang, er nu inddæmmet og tørlagt.

Mod Sydvest begrænses Gamborg Fjord af den lange og paa de fleste Steder meget smalle Halvø Fynsskov, der ligeledes har Retningen S $\varnothing-N V$. Højderne paa Fynsskov ere ikke betydelige, sjældent over $10 \mathrm{~m}$., og Terrainformerne synes ikke at staa $\mathrm{i}$ nogen væsentlig Forbindelse med Halvøens Form. Gaar man derimod fra Halvøens Rod videre mod Sydøst ind i Landet, samles Bakkerne til en enkelt, smal og meget udpræget Højderyg, der over Fyns strækker sig ind til Hovedlandevejen og derfra kan følges videre langs Vejen gennem Tybrind Skov. Udenfor Kortbladets Grænse kan dette Højdedrag følges endnu en lang Strækning - over Ruerne og Haare Bjerge - , og da det for største Delen er bevokset med Naaleskov, er det meget iøjnefaldende i Terrainet. Højderne, der mod Vest omkring Fyns vare $16-17 \mathrm{~m}$. o. H., stige mod Sydøst og naa i Tybrind Skov $53 \mathrm{~m}$. o. H., det højeste Punkt paa Kortbladets fynske Del.

Højderyggen ved Fyns skilles ved Fyns Vig og de lavtliggende Enge omkring Hovedsø fra det jævne, lave Land mellem Tybrind og Rud. Højden over Havet er kun en halv Snes Meter, Terrainformerne have intet karakteristisk Præg, og først længst mod Vest samle de sig i en lav, flad Ryg, der fra Rud skyder sig som en Halvø ud i Lillebelt.

Længere mod Syd finder man intet i Terrainformerne, der svarer til de tidligere omtalte Lavninger og Højdedrag med Retningen SØNV eller Ø-V; kun i store Træk kan man herunder henregne Tybrind Vig med dens Fortsættelse mod Øst ind gennem de lave Engdrag, samt den Syd derfor liggende Wedellsborg-Halvø. Denne sidste har mod Øst en ret stærkt bølget Overflade med Højder paa henved $30 \mathrm{~m}$.; mod Vest er den lavere og temmelig jævn.

De indenfor Kortbladsomraadet liggende Øer i Lillebelt: Brandsø, Bogø med Egholm, Bastholm og Smaaholmene, samt Thorø tæt Sydvest for Assens, ere alle lave med Højder paa indtil 9 m., og kunne ikke betragtes som Fortsættelse af noget af de nævnte Højdedrag paa Fyn.

Lillebelt viser som bekendt meget vekslende Dybdeforhold. Nord for Kortbladgrænsen, mellem Fredericia og Middelfart, hvor 


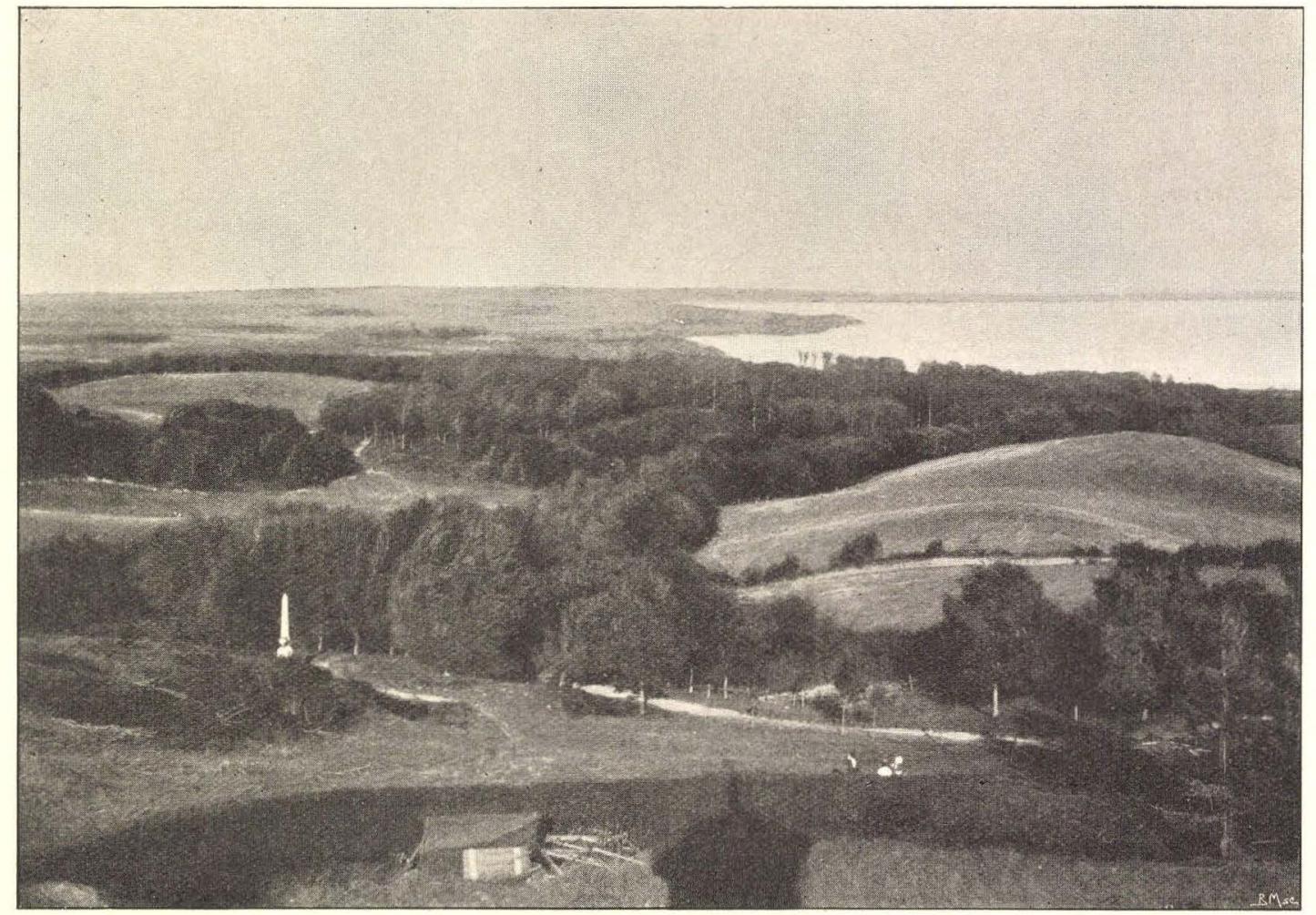

Fig. 1. Udsigt fra Toppen af Skamlingsbanke mod Nordøst. (Clichéen udlaant af Den danske Turistforening). 
Beltet er meget smalt, danner det en dyb Rende med indtil $50 \mathrm{~m}$. Vand, og det dybe Vand gaar tæet ind til Kysten. Dette Dyb fortsættes Syd paa mellem Fænø og Stendrup Hage; Dybderne ere her noget varierende, fra 30 til $50 \mathrm{~m}$., enkelte Steder endog indtil $80 \mathrm{~m}$. Fra Stendrup Hage mod Sydvest bliver Landgrunden bredere, og Bunden falder jævnt udad. Mellem Stendrup Hage og Fynsskov findes endnu 30-50 m. Vand, men Syd derfor, hvor Beltet danner den store Bredning Nord for Brandsø, blive Dybderne mindre og samtidig mere ensartede, varierende mellem 10 og $20 \mathrm{~m}$. Brandsø danner det øverste af en større Grund, der kun mod Nordøst falder stejlt af mod det dybe Vand. Ogsaa omkring Bogø findes en bred Landgrund, der mod Nordvest strækker sig ud omkring Egholm. Mod Sydvest adskilles Bogø-Grunden ved den 10-12 m. dybe, meget smalle "Fyrrende" fra Flakket omkring Bastholm, Smaaholme og Orø, der igen ved det smalle, dybe Orø Sund skilles fra Slesvig. I det brede Farvand mellem Bogø og Fyn er Dybden c. 20 m.; dog ligger der $1-1 \frac{1}{2} \mathrm{~km}$. Øst for Bogø et Rev, Remmen, paa hvilket der kun er 3-4 m. Vand. Revet, der har en Længde af c. $3 \mathrm{~km}$., løber parallelt med Bogøs Østkyst og er skilt fra Øen ved en 8$10 \mathrm{~m}$. dyb Rende. Syd for Bogø bliver Farvandet igen bredt med jævn og flad Bund og Dybder paa $20-25 \mathrm{~m}$.

Den jydske og største Del af Kortbladsomraadet frembyder ret vekslende Terrainformer. Længst mod Nordøst mellem Stendrup By og Stendrup Hage danner Landet en overordentlig jævn Flade med en Højde af $5-15 \mathrm{~m}$; ud mod Lillebelt findes af og til lave Klinter paa nogle faa Meters Højde, og mod Sydvest gaar Terrainet jævnt og umærkeligt over i de store Enge omkring Solkjær Aa.

Som det ses af Kortet, løber Solkjær Aa i en stor Bue; den kommer fra en Mose ved Grundinghoved Sydvest for Skamlingsbanke, løber derfra mod Nordvest og Nord til Bjært, hvor Aaen gør en skarp Drejning og løber mod Øst og Sydøst forbi Stendrup til Lillebelt. Medens den i sit nedre Løb, fra Stendrup til Kysten, flyder gennem en bred Dal, hvis Grænser mod det omgivende Land ere fuldstændig udviskede, er Aadalens Tværsnit Vest for Stendrup og omkring Bjært næsten U-formet med plan Bund og høje, temmelig stejle Sider.

Det Terrain, der mod Nord og Vest begrænses af Solkjær Aa, er i sin nordlige Del jæunt og temmelig fladt, men har dog et noget stærkere Fald ud mod Kysten end Landet Øst for Stendrup. Mod Syd beherskes det fuldstændigt af Skamlingsbanke, der som en i omtrent Nord-Syd løbende Ryg hæver sig til $113 \mathrm{~m}$. o. H., c. $60 \mathrm{~m}$. over det omgivende Terrain (se Fig. 1 og Fig. 8-10). Syd for Skamlingsbanke falder Landet jævnt ned mod Hejlsminde og Kjærmølle 
Aa; ejendommelig er dog det temmelig stejle Bakkeaffald, der fra Sydenden af Strandskov og Hejls Gaard strækker sig mod Vestsydvest til den slesvigske Grænse Vest for Fiskbæk Kjær.

Vest for Solkjær Aa hæver Terrainet sig som store, flade Kupler eller højtliggende, jævnt Land; nordligst ved Højgaard naaer det til $60 \mathrm{~m}$. o. H., Syd for Vonsild findes ved Kokholm samme Højde, og endnu sydligere, ved Sjølund og Sjølund Skov, træffes Højder paa $60-70 \mathrm{~m}$. o. H.

Vest for dette Højdedrag findes et lavere liggende Terrain, hvor smaakuperede Strækninger veksle med flade Sletter eller med udstrakte Moser. Overfladevandet søger herfra dels mod Nordøst og Nord gennem Dalbymølle Bæk og Sest Aa til Kolding Fjord, dels mod Syd gennem Fovsaa til Ribe Aa. Da dette Vandskel ligger betydeligt lavere end Landet baade Øst og Vest derfor, og da heller ikke Niveauforskellen langs en Linie fra Nord til Syd er af nogen Betydning, spiller det ingen Rolle i Terrainet. Sest Aa, der kommer fra den store Svanmose, flyder i sit nedre Løb - fra Vonsild til Kortbladets Nordgrænse - gennem en dybt nedskaaret Dal med høje, stejle Sider. Fovsaa, der løber mod Sydvest, og som i Kortets Vestrand danner Grænsen mod Slesvig, passerer gennem udstrakte Kær og Mosedrag; disse begrænses mod Syd af et uregelmæssigt Bakkeparti, der strækker sig fra Tapsore til Brendore, tæt Nord for den slesvigske Grænse.

Vest for det ovenfor omtalte, lavere liggende Terrain, der fra Vonsild og Sest Skov $(40-50 \mathrm{~m}$. o. H.) strækker sig over Svanmose (52 m. о. H.) til Dridekjær (41 m. o. H.). hæver Landet sig igen og danner en flad Ryg $(60-70 \mathrm{~m}$. o. H.), der fra Kortbladets Nordrand mellem Langholt Gaard og Sest Skovgaard strækker sig mod Sydsydvest over Fovslet Skov og skærer Kortbladgrænsen Vest for Tagkjær, tæt Nord for Ødis By. Denne Højderyg, hvis Bredde er ret vekslende, og som paa adskillige Steder naaer op til $72-73 \mathrm{~m}$. o. H., danner paa en længere Strækning Vandskellet mellem Øst og Vest, idet Overfladevandet fra dens østlige Skraaning søger til Kolding Fjord og fra den vestlige Skraaning løber gennem Kongeaa til Vesterhavet.

Aaløbene ere allerede omtalte i det foregaaende; kun enkelte, som f. Eks. Solkjær Aa, have en større Længde og Vandmængde.

Af Indsøer findes ingen af Betydning; nævnes maa dog de smaa Kystsøer, begrænsede udad til af Strandvolde og oftest med brakt Vand, der træffes flere Steder paa Bogø og langs den fynske Kyst.

Blandt inddæmmede og udtørrede Arealer er Fyns Vang ved den inderste Ende af Gamborg Fjord det største; skønt Bunden her ligger adskilligt under Havets Niveau, er hele Arealet nu fuldstændig tørlagt og afgiver fortrinlig Eng. 
Større uopdyrkede Strækninger træffes kun i Kortbladets vestlige Del ude paa de store Mosearealer, som f. Eks. Svanmose.

Skove findes i Mængde, oftest som Smaaskove, saavel paa den fynske som paa den jydske Del af Kortbladsomraadet. Af større Skovstrækninger kan nævnes Skovene omkring Tybrind og Wedellsborg, og Vest for Lillebelt: Stendrup Midtskor og Sønderskov, det Skovbælte, der fra Skamlingsbankes Østside strækker sig Syd paa langs Kysten til Vargaarde, Fovslet Skov o. fl. 


\section{Aflejringer ældre end Kvartærperioden.}

Aflejringer fra Tertiær- og Kridttiden træde ikke frem i Overfladen paa Kortbladet Skamlingsbanke, og kun paa et Par Steder er deres Tilstedeværelse eftervist ved Boringer.

Ved den dybeste Boring indenfor Kortbladsomraadet, ved Wedellsborg ${ }^{1}$ ), fandtes $47,2 \mathrm{~m}$. kvartære Lag, derunder 101,8 m. tertiære Lag, og derunder Kalk, hvori der boredes $16 \mathrm{~m}$. Beskrivelsen af de tertiære Lag: øverst Ler, der var gulgraat eller saa stærkt rødt, at Vandet farvedes deraf, leder Tanken hen paa det brogede, plastiske Ler i Røgle Klint, Øst for Strib. De derunder liggende Lag, hvor haard Skifer veksler med blødere Lerlag, tyde paa paleocænt Ler svarende til Kertemindeleret. De haarde og løsere Lag af Kalksten, som fandtes nederst, høre utvivlsomt til Danien.

Ved en Boring Vest for Lillebelt, ved Frederikshøj $\mathrm{Kro}^{2}$ ) umiddelbart ved den slesvigske Grænse, fandt man øverst $50 \mathrm{~m}$. Sand og Mergel, der vistnok alt er af glacial Oprindelse, og derunder "Brunkuller", rimeligvis det mørke, letkendelige Glimmerler.

Paa adskillige Steder finder man i de kvartære Jordlag Antydninger af Undergrundens Beskaffenhed. Saaledes optræder en graa, delvis forkislet, paleocæn Mergel i overordentlig stor Mængde i Diluvialgruset i Terrainet mellem Aastorp, Taps og Frederikshøj Kro $\left.(\mathrm{O} 3, \mathrm{P} 2)^{3}\right)$ og derfra videre Vest paa. Denne Stenart, der let springer i Stykker eller knuses ved Slag eller Tryk, forekommer paa sine

1) Se Boring XII i Tillæget. Boringen udførtes i 1882-1883; Borejournalerne opbevares paa Mineralogisk Museum, men Prøver af Jordlagene findes desværre ikke.

${ }^{2}$ ) Se Boring XX i Tillæget. Boringen udførtes i 1876; Borejournalerne opbevares paa Mineralogisk Museum, men heller ikke herfra haves der Boreprøver.

3) Bogstaver og Tal i Parenthes efter et Stednavn angive Stedets Beliggenhed paa det medfølgende geologiske Kort, der ved Bogstaver og Tal i Kortets Rand er inddelt i tilsvarende Rektangler (Maalebordsblade). 
Steder saa hyppigt, at den maa sorteres fra for ikke at forringe Grusets Værdi. Ogsaa i Moræneleret Øst paa, i Klinten Nord for Vargaarde (N3), er den almindelig. Dens stærkt begrænsede Udbredelse og dens Fraværelse i de løse Jordlag Øst for Lillebelt tyder paa, at den ikke er transporteret langt fra sit Hjemsted, der rimeligvis maa søges ude i Lillebelt.

Et tilsvarende Forhold findes i de nær Kortbladets Nordgrænse liggende Klinter paa Vestsiden af Lillebelt, idet man ved Gammel Aalbo, Stendrup Hage og Bjærtstrand kan finde Striber af Glimmerler i Moræneler, eller dette kan - som Nord for Gammel Aalbo i Klintens Fod og i Stranden udenfor have en meget mørk Farve, være meget glimmerholdigt og næsten stenfrit, og paa en Maade betegnes som en Lokalmoræne af Glimmerler.

I Skamlingsbanke finder man paa enkelte Steder skarpt begrænsede Partier af lyst, fint Glimmersand eller af fint Kvartsgrus. Lejringsforholdene, der senere skulle omtales, vise, at disse Lag af umiskendeligt tertiært Præg ikke ere faststaaende, men kun udgøre mindre Indlag i den hovedsagelig af fluvioglaciale Lag opbyggede Bakkeryg. 


\section{Kvartæerperiodens Aflejringer.}

\section{Diluviale Aflejringer.}

\section{A. Ikke-lagdelte Diluvialaflejringer.}

\section{Moræneler og Morænesand.}

Mellem de to Bundmoræne-Dannelser: Moræneler og Morænesand er det ofte vanskeligt at trække en Grænse; de ere dannede paa samme Maade, Lejringsforholdene ere de samme, de erstatte hyppigt hinanden, og de to Typer ere forbundne ved en kontinuerlig Række af Overgangsformer. Paa Kortbladet Skamlingsbanke optræder Morænesandet sjældnere, oftest paa smaa Arealer, hvorimod Moræneleret er den mest udbredte Overfladedannelse.

Moræneleret har det sædvanlige Udseende; hverken Indholdet af Sten eller de grovere og finere Bestanddeles indbyrdes Mængdeforhold afviger væsentligt fra, hvad der findes paa andre Steder. Men ensartet er Moræneleret dog langtfra; medens Leret i enkelte Strøg kan være temmelig sandet, kan det paa andre Steder være meget fedt. Dette sidste er f. Eks. Tilfældet paa en mindre Strækning Sydrest for Vindemose (NO3) samt i Terrainet Øst og Sydøst for Stendrup (N 2); i de lave Klinter mellem Mundingen af Solkjær Aa og Stendrup Hage ses Profiler i dette fede, meget stenfattige Moræneler. Iøvrigt henvises til de i Tillæg II opførte mekaniske Analyser af Moræneler.

Nærmest Overfladen er Moræneleret stærkt paavirket af Planteog Dyrelivet (se Fig. 2, Side 11), og indtil en Dybde af $1-1^{1 / 2}-2 \mathrm{~m}$. er den oprindelig tilstedeværende, kulsure Kalk opløst af det nedsivende, kulsyreholdige Regnvand. Undertiden kan noget af demne Kalk igen være udskilt i de Rør, der ere dannede af nu bortraad- 


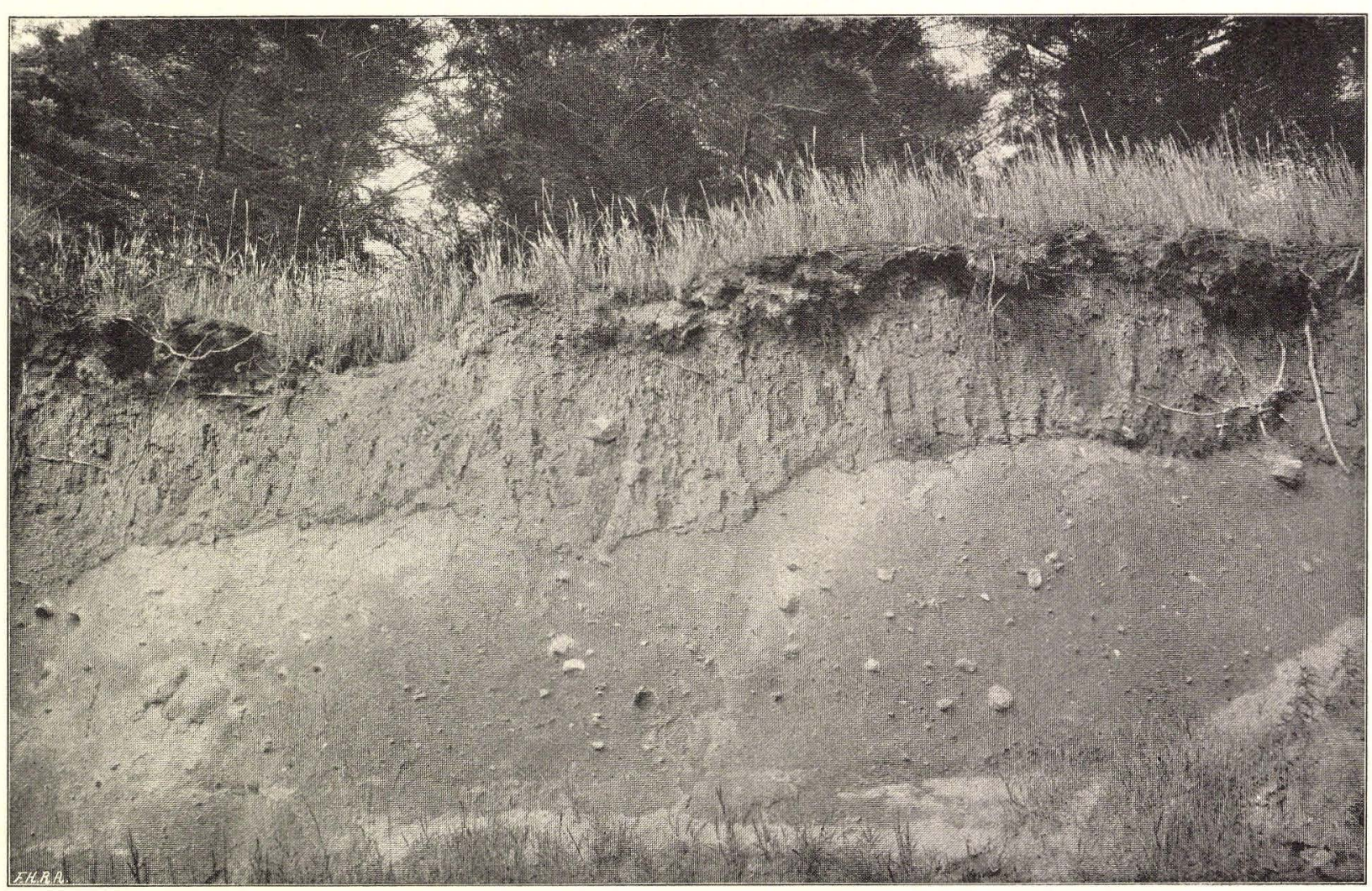

Fig. 2. Forvitret Moræneler i Klinten SV. for Wedellsborg. 
nede Planterødder. Kalkmængden i Moræneleret er meget varierende; gennemsnitlig kan den sættes til $15-20 \%$, i fedt Moræneler indtil $25 \%$ kulsur Kalk. Kun i faa Tilfælde er den højere, saaledes fandtes i en Prøve af meget fedt, stenfattigt Moræneler ved Stendrup Hage $32,6 \%$ kulsur Kalk. Jernforbindelserne, der altid findes i Moræneleret, ere i de øvre Lag omdannede til rustfarvede Jerntveilteforbindelser, der give Leret dets gule eller rødbrune Farve. Undertiden kan noget af Jernet, paa samme Maade som Kalken, være bleven opløst og igen udskilt i Hulheder, som ærtstore Konkretioner eller som Overtræk paa Stenene. Som Regel er Jernforbindelsernes Iltning naaet ned til større Dybde end Kalkens Udvaskning, saaledes at der mellem de dybere, upaavirkede Lag, der sædvanlig have en graa, i vaad Tilstand mørk blaagraa Farve (Blaaler), og det øverste, kalkfri, iltede, rødbrune Ler (Rødler) findes en Overgangszone, der efter sin Farve nærmest maa kaldes Rødler, men paa Grund af sit Kalkindhold kan anvendes som Mergel. Eksempler herpaa give de i Tillæget anførte Boreprofiler I, II, IV, VI, IX og XV.

Hvor Morænelerets Mægtighed kun er et Par Meter eller mindre, er hele Laget oftest iltet og hyppigt ogsaa kalkfrit, i Særdeleshed hvis Underlaget er Sand, der tillader en let Passage for Luft og Vand. Morænesandet, der ved sit ringere Lerindhold er lettere gennemtrængeligt for Luft og Vand, er næsten altid iltet gennem hele sin Mrgtighed og har faaet en gulbrun Farve. Derimod finder man ret ofte kalkholdigt Morænesand, i Reglen hvor Underlaget er Moræneler eller stenfrit Ler, eller paa Steder, hvor Morænesandet optræder som Bænke i lagdelte, diluviale Dannelser.

Morænelerets Mægtighed er yderst varierende. Enkelte Steder paa dette Kortblad synes det at danne massive Banker, men det er dog Undtagelser. Ser man paa Forholdene i store Træk, faar man oftest det Indtryk, at Moræneleret (og Morænesandet) her optræder som en typisk Bundmoræne, der er aflejret over én paa store Strækninger meget jævn, paa andre Steder temmelig kuperet Undergrund paa en saadan Maade, at mange Fordybninger og Lavninger ere udfyldte, og at hovedsagelig kun de større Dalstrøg, hvis Retning var omtrent parallel med Indlandsisens Bevægelsesretning, ere bevarede. Moræneleret ligger altsaa som en Kappe over de lagdelte Diluvialdannelser, udjævner mange af Undergrundens Uregelmæssigheder og giver et Landskab med bølgende, afrundede Former. Kun paa enkelte Strøg giver Morænelæret Anledning til et uroligt og smaatoppet Terrain.

Paa Kortbladets fynske Del vil man mod Nord, f. Eks. omkring Gamborg, se, at det jævnt bølgede Højland dækkes af Moræneler, medens det underliggende Diluvialsand kommer frem i Skrænterne 
ned mod Aaløbene eller ud mod Lillebelt. Mod Nordøst omkring Nørre Aaby Station er Morænedækkets Mægtighed meget varierende. Tæt Nordvest for Stationen gaa diluviale Sand- og Gruslag udækkede i Dagen paa adskillige Steder, medens Moræneleret i selve Stationsbyen har en Mægtighed af en halv Snes Meter (Boring I og II i Tillæget); et enkelt Sted, ved Nørre Aaby Mejeri, naaer Mægtigheden endog op til $20 \mathrm{~m}$. Syd for Stationen tynder Moræeneleret ud, og det lagdelte Diluvium kommer frem til Overfladen. Endnu sydligere, i Brangstrup By, dækkes de lagdelte Dannelser igen af Moræneler, der her naaer en Mægtighed af $10 \mathrm{~m}$.

Saaledes veksle Forholdene stadig. I Ubby (L 3) har Moræneleret en Mægtighed af $18 \mathrm{~m}$. (Boring VI), men baade mod Nordøst og Nordvest tynder Laget ud, og det nedre Diluvium kommer frem i Overfladen.

Syd herfor, paa Strækningen mellem Fyns og Tybrind (L 3, 2), er Moræneleret af meget underordnet Betydning som Overfladedannelse; saa godt som hele dette Højdedrag bestaar af lagdelt Diluvium, der ogsaa gaar i Dagen over store Strækninger paa Lavlandet Sydvest derfor. Moræneleret optræder her paa det flade Land først som smaa, isolerede Partier, der, jo længere man kommer mod Syd og Vest, mere og mere samles til et Dække over Diluvialsandet.

Syd for Hygen Bæk bliver Moræneleret igen dominerende som Overfladedannelse og dækker omtrent hele den store WedellsborgHalvø. Dets Mægtighed kan gennemsnitlig anslaas til en halv Snes Meter (se Boringerne IX, X og XI i Tillæget), dog kan Lerdækket ogsaa her blive tyndt eller helt mangle, saa at det nedre Diluvium kommer frem til Overfladen.

Ligesom Boringerne og Brøndgravningerne vise ogsaa Klinterne ud mod Lillebelt en meget vekslende Mægtighed for Moræneleret. Snart ses Lerklinter paa indtil 10 Meters Højde, andre Steder derimod Skrænter, hvor Diluvialsandet enten naaer helt op til Mulden eller kun dækkes af $1-2 \mathrm{~m}$. Moræneler.

Ogsaa paa Øerne i Lillebelt: Brandsø, Bogø med Smaaholme og Thorø, er Moræneleret den vigtigste eller i alt Fald en meget fremtrædende Overfladedannelse. Paa Thorø ser man i et fortrinligt Profil Grænsen mellem Moræneleret og dets Underlag Diluvialsandet, der kommer frem i en Del af Vestklinten (Fig. 3, Side 15), medens Moræneleret ved Øens Sydspids indtager hele Klintens Højde og staar som en lodret Væg ud mod Lillebelt uden at være beskyttet af nogen Forstrand (Fig. 4, Side 17).

Paa Kortbladets jydske Del er Moræneleret ligeledes den vigtigste Overfladedannelse. I Særdeleshed imod Nord, fra Stendrup Hage ved Lillebelt over Stendrup, Bjært (O 3) og til Vonsild (P 3) er den langt 


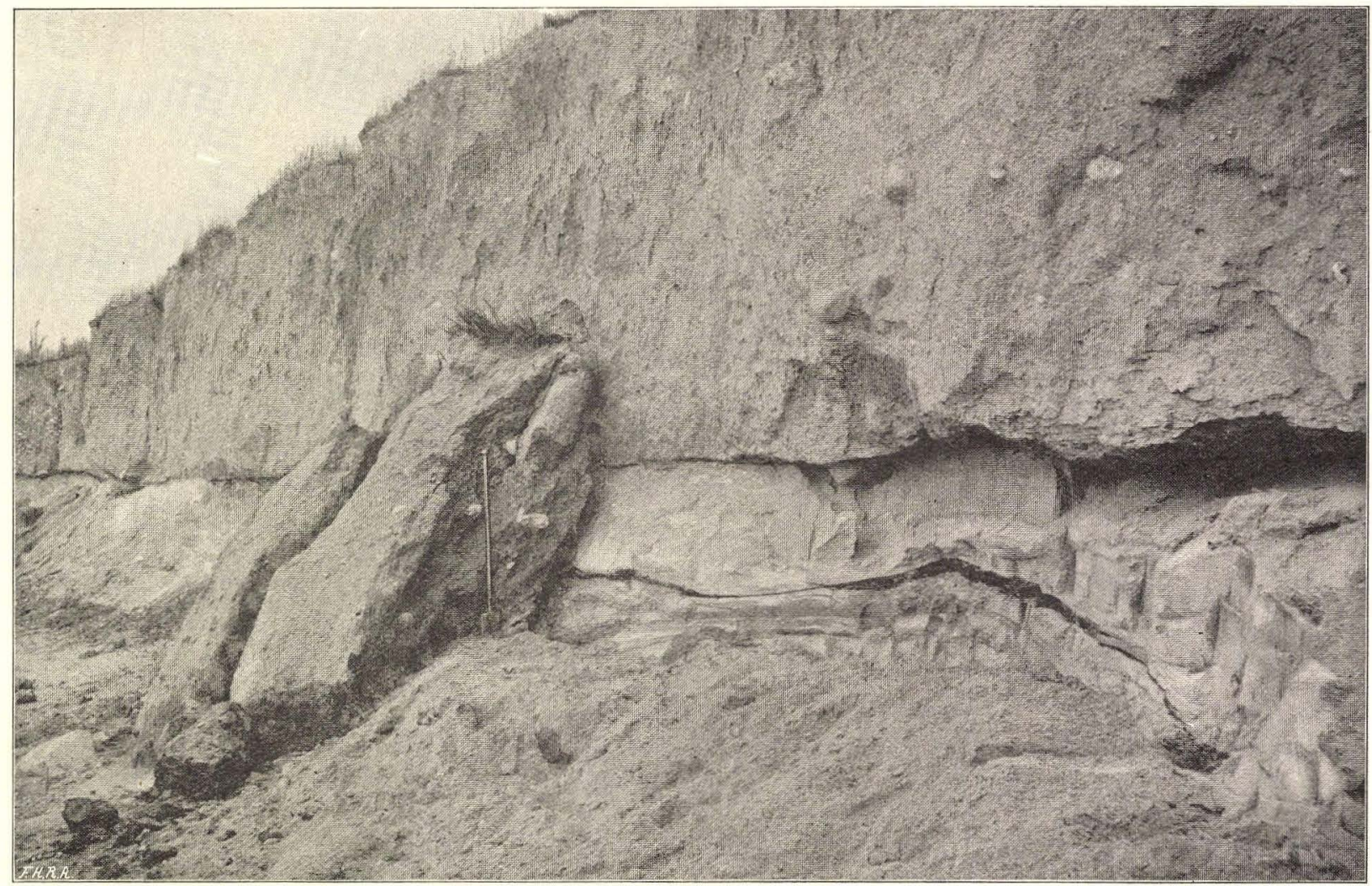

Fig. 3. Moræneler over lagdelt Diluvialsand. Klint paa Vestsiden af Thorø. 


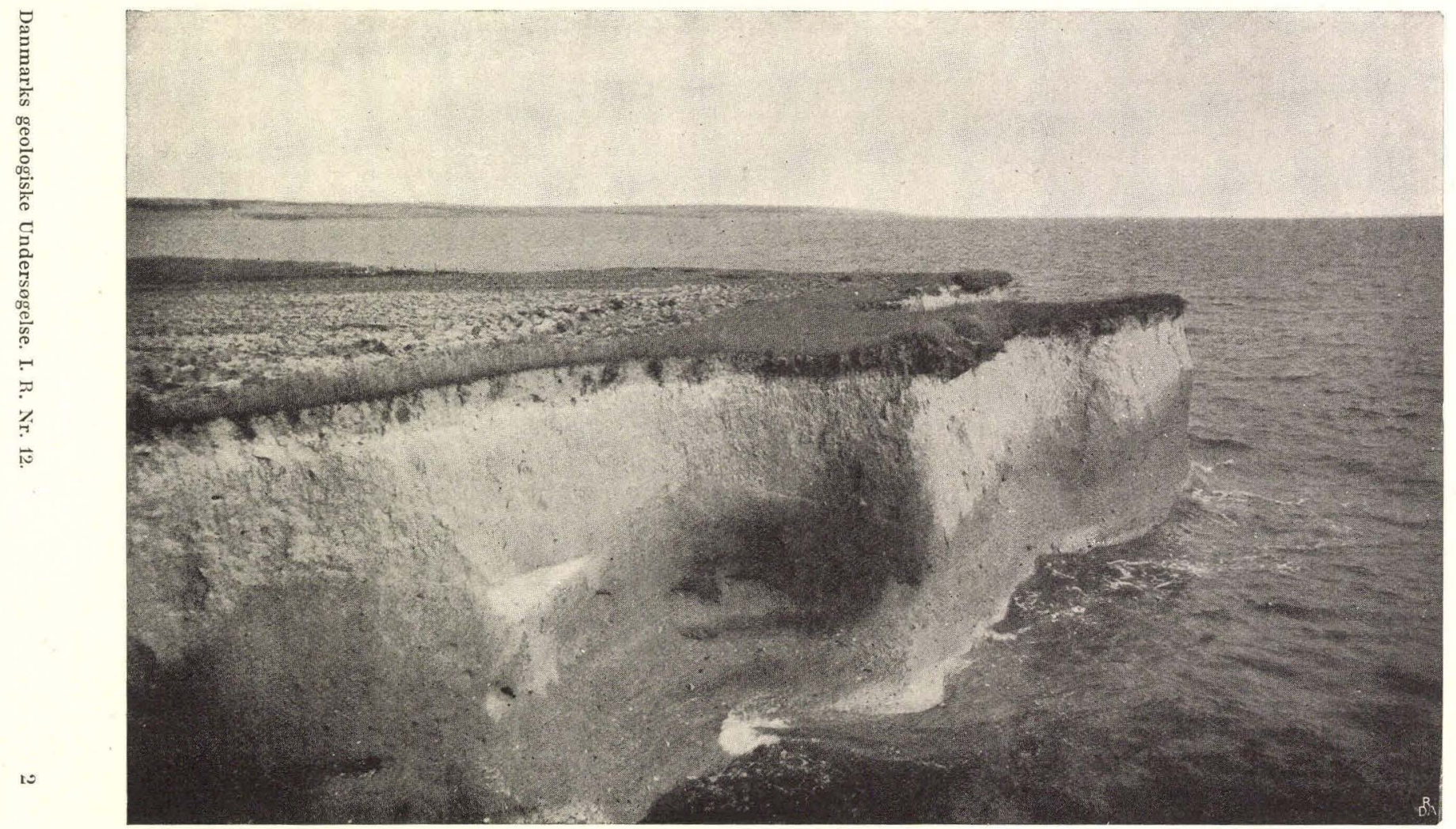

Fig. 4. Morænelerklint. Sydenden af Thorø

(A. Jessen fot. - Clichéen udlaant af Den danske Turistforening). 
overvejende Del af Overfladen Moræneler, til Dels af meget fed Beskaffenhed.

Ligesom paa den fynske Side er Morænelerets Mægtighed noget varierende, dog ikke saa meget paa de jævne Strækninger mod Nord og Nordøst som i det kuperede Terrain mod Syd og Vest. I Klinterne ud mod Lillebelt naaer Moræneleret ved Stendrup Hage en Mægtighed af over $9 \mathrm{~m}$. Sydligere, omkring Mundingen af Solkjær Aa, træder Sandet frem i Foden af Klinterne, og Morænedækkets Mægtighed er kun et Par Meter. Men endnu sydligere, ved Vindemose inde i Mosvig, findes over $13 \mathrm{~m}$. høje Skrænter, der bestaa af Moræneler fra øverst til nederst. Over det flade Terrain Øst for Stendrup ligger Moræneleret som et jævnt Dække med en Mægtighed af $6-8 \mathrm{~m}$. og mangler kun paa ganske enkelte Smaapletter. Mellem Stendrup og Bjært ses det nedre Diluvium ret almindeligt i de høje Skrænter langs Solkjær Aa, medens Plateauerne paa begge Sider ere dækkede af Moræneler, hvad der tyder paa, at Aadalen i alt Fald delvis er udgravet, efter at Moræneleret aflejredes.

Omkring Ajtrup og Bjært er Morænelerets Mægtighed ikke stor, men tiltager igen mod Vest og Sydvest, hvor Leret ligger som en næsten sammenhængende Kappe over den flade Banke omkring Bøgelund og Højgaard (O 3). Vest herfor bliver Morænelerets Mægtighed igen vekslende; paa store Strækninger omkring Hovedlandevejen fra Kolding til Haderslev mangler det fuldstændigt, saa at det nedre Diluvium gaar i Dagen, medens det paa Steder tæt derved kan naa en betydelig Mrgtighed, saaledes f. Eks. ved Nørgaard Nord for Vonsild, hvor man med en $9 \mathrm{~m}$. dyb Brønd ikke naaede gennem Leret. Ud mod Kortets Vestgrænse, i Særdeleshed i det høje Terrain fra Fovslet Skov mod NNO. over Sest Skovgaard, er Morænelerets Mægtighed ret betydelig; Syd for Forslet Skov og Svanmose er Mægtigheden flere Steder over $8 \mathrm{~m}$., hyppigt dog langt mindre, og paa adskillige Punkter træder det nedenunder liggende lagdelte Sand frem.

Længere mod Syd, henimod den slesvigske Grænse, er Morænelerdækket ikke saa jæunt og sammenhængende, og dets Mægtighed er langt mere varierende. Dette ses allerede indenfor Mosvig, hvor Skamlingsbanke hæver sig højt over det omgivende Land. Man finder dér en uafbrudt Vekslen mellem Moræneler og Diluvialsand, hvor det første ligger som uregelmæssige Partier eller tilsyneladende løsrerne Flager over Sandet, og med langt mere uregelmæssige Konturer, end det har været muligt at angive paa det medfølgende geologiske Kort. Mægtigheden er samtidig stærkt vekslende, fra $1 / 2$ til $8 \mathrm{~m}$. eller mere, og paa flere Steder tyde Profilerne paa, at Moræneleret staar med næsten lodret Grænse mod Bakkesandet. I et 
Strøg fra Skamlingsbanke mod Sydvest og Vest ere Jordbundsforholdene ligeledes meget uensartede; paa talrige Steder naaer Diluvialsandet frem i Overfladen, medens man paa dér imellem liggende Punkter kan finde indtil $7 \mathrm{~m}$. Moræneler eller endog mere.

Syd og Sydøst for Skamlingsbanke er Moræneleret overvejende. Det danner her et frugtbart, bølget Landskab, der nærmest Kysten er dækket af Smaaskove; paa den fremspringende Pynt Nord for Vargaarde, Øst for Hejls, staar Moræneleret som en 10-13 m. høj, for oven lodret Klint (se Fig. 5, Side 21).

Længst mod Sydøst ved Hejlsminde indtage de lagdelte diluviale Dannelser et betydeligt Areal langs Lillebelts Kyst, medens Moræneleret dækker det omgivende, højere Land. Morænelerets Fraværelse i det lave Terrain skyldes rimeligvis Indlandsisens eroderende Virkning, idet Friktionen mod Undergrunden maa have være meget stor netop her, hvor Isen har skullet bevæge sig fra Lillebelts Bund op over det høje Land mod Vest. Noget indenfor Kysten, omkring Hejls, dækkes næsten hele Terrainet af Moræneler, der oftest har en betydelig Mægtighed. I Hejls By er det saaledes 13-17 m. mægtigt og hviler paa vandførende Sand; enhver Boring dér giver en Springkilde. Ved Hejls Kro, $500 \mathrm{~m}$. Nord for Kirken, er Morænelerets Mrgtighed 17,3 m. (Boring XIV), ude i Engen Øst for Kirken 9,4 m. (Boring XVII) og ved Stavnsbjerg ude ved Hejlsminde 12,5 m. (Boring XVI); ved Kjær Mølle, umiddelbart ved den slesvigske Grænse, naaer det den største kendte Mrgtighed indenfor Kortbladsomraadet, nemlig 23,5 m. (Boring XVIII). Det synes, som om der omkring og Vest for Hejls, langs Kjærmølle Aa, har eksisteret en stor Lavning, der ved den sidste Isdækning delvis er bleven udfyldt med Moræneler. Lavningens Nordrand, der fra Fiskbæk Kjær strækker sig mod ØNØ. og NØ. til Sydenden af Strandskov, ses endnu tydeligt (sml. Side 6) og fremgaar ogsaa af Højdekurvernes Forløb (se det medfølgende geologiske Kort). Gaar man op over denne Skrænt mod Nordvest til Vejstruprød, bliver Morænelerets Mægtighed langt mindre, paa en Del Steder kommer det lagdelte Grus og Sand endog frem i Overfladen.

Vest herfor, omkring Kolding-Haderslev Landevejen, træffer man næsten overalt Moræneler i Overfladen, men dets Mægtighed er oftest ringe. Enkelte Steder, som f. Eks. ved Taps Kirke, kan Mægtigheden stige til 5,5 m., paa andre Punkter er den kun 1-2 m., og mod Nord omkring Johanover og Kokholm forsvinder Moræneleret helt, saa at det nedenunder liggende Sand kommer frem i Dagen.

Vest for Taps, hvor Overfladen er kuperet, og hvor store, tørvefyldte Lavninger veksle med uregelmæssige Bakkedrag, er Morænelerets Udbredelse og Mægtighed en anden end paa Slettelandet. Paa 


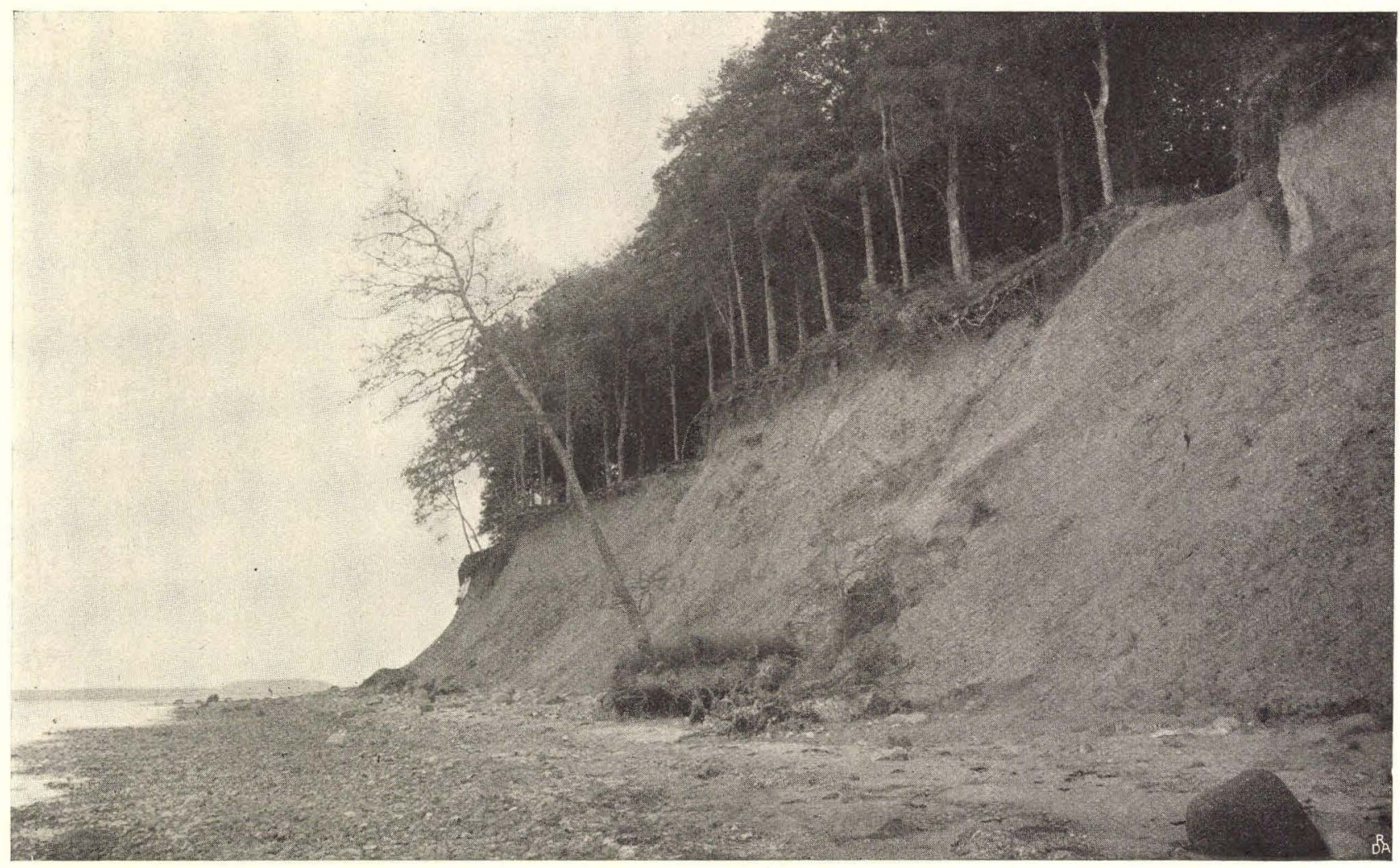

Fig. 5. Morænelerklint Nord for Vargaarde.

(A. Jessen fot. - Clichéen udlaant af Den danske Turistforening). 
talrige Steder mangler Morænen, og det lagdelte Diluvium ligger blottet, oftest i de højeste Bakker og i isolerede Toppe, og ligesom i Skamlingsbanke kan Moræneleret faa Meter fra sin Grænse mod Sandet opnaa en Mægtighed af 6-7 m., saaledes f. Eks. red Brendore Mølle (Boring XXI og XXII).

Morænelerets og Morænesandets Lejringsforhold ere meget ensartede over hele Kortbladsomraadet. Intet Steds ere disse Morænedannelser iagttagne direkte hvilende paa prækvartære Lag; overalt, hvor deres Underlag er kendt, har dette vist sig at være lagdelte diluviale Dannelser: Ler, Sand eller Grus. Det er muligt, at Morænedannelserne ude i Lillebelt ligge direkte paa tertiære Lag; i alt Fald maa Landisen, som nævnt Side 8-9, under sin Bevægelse tværs over denne Lavning have været i Berøring med Tertiæret, da der i dens Bundmoræne kan findes saa meget tertiært Materiale.

I Reglen optræder Moræneleret som et enkelt Lag, der - naar man ser bort fra den sekundære Forvitring - er ensartet helt igennem. Dog vil man undertiden, f. Eks. i Klinterne ved Lillebelt, kunne finde flere Bænke af Moræneler, adskilte ved Lag af stenfrit Ler. Dette er saaledes Tilfældet Vest for Gamborg (L, M 3), hvor der i Skrænten paa Nordsiden af Gamborg Fjord ses øverst $1{ }^{1 / 2}$ $2^{1} / 2 \mathrm{~m}$. Moræneler, derunder $1-1^{1} / 2 \mathrm{~m}$. stenfrit Ler, knust og med svag horizontal Lagdeling, derunder atter $2 \mathrm{~m}$. Moræneler og nederst $1 \frac{1}{2}-2 \mathrm{~m}$. knust Diluvialler, der hviler paa Diluvialsand.

Omtrent den samme Lagserie med to Morænelerbænke, adskilte ved og hvilende paa Diluvialler, der igen underlejres af Diluvialsand, findes i Klinten paa Sydsiden af Wedellsborg-Halvøen (L 2). Gaar man fra Rørdam mod Vest langs Stranden, ses i den lave Klint under Skoven kun Moræneler, der nærmest Jordoverfladen er meget stærkt forvitret og omdannet. Det har en mørk rødbrun Farve, er fuldstændig kalkfrit og spalter ved Indtørring i lange, lodret stillede Prismer (se Fig. 2, Side 11). Længere Vest paa, hvor Klinten er højere, findes øverst 3-4 m. Moræneler og derunder lagdelt, stenfrit Ler, der mod Vest stiger op gennem Klinten i flade Bølger. $500 \mathrm{~m}$. fra Nedkørslen ved Rørdam er Profilet følgende (se Fig. 6-7, Side 25): øverst et Par Meter Moræneler, derunder $1-1^{1 / 2} \mathrm{~m}$. lagdelt Diluvialler, hvor de enkelte Lerlag have en Tykkelse af $1 / 2$ til $5---8 \mathrm{~cm}$. og ere adskilte ved tynde Sandlag; derunder $1 \frac{1}{2} \mathrm{~m}$. Moræneler af typisk Udseende, og derunder $1 / 3 \mathrm{~m}$. knust Diluvialler, der falder fra hinanden i skarpkantede Brokker med blanke Glideflader. Nedefter bliver dette Ler mere sandet og gaar uden skarp Grænse over i stenfrit Diluvialsand, der i Klintens Fod viser en tydelig diskordant Lagdeling, undertiden dog ogsaa foldede Lag. 
Længere mod Vest, hvor Klinten igen bliver lavere, forsvinder efterhaanden de nederste Lag; det mellem de to Morænelerbænke liggende Diluvialler kan blive over $2 \mathrm{~m}$. mægtigt, og samtidig danner det her en Overgangsform til lagdelt Moræneler, idet Leret indeholder en Mængde Smaasten og Gruskorn spredte omkring i Lagene. Længst mod Vest ses udelukkende Moræneler, af og til med Indlag af Diluvialgrus eller med horizontalt liggende Rækker af større Sten. Ogsaa hele Klinten langs Halvøens Vestkyst bestaar af Moræneler.

Et lignende Profil findes paa Sydsiden af Halvøen Fynsskov, hvor man i de 3-6 m. høje Klinter Vest og Øst for Tøn æs Enghave ser: øverst et henved $1 \mathrm{~m}$. mægtigt Lag rødbrunt, stærkt forvitiet, men iøvrigt typisk Moræneler fuldstændig lig det nylig omtalte forvitrede Moræneler ved Rørdam; derunder en 1-2m. mægtig Bænk af lagdelt Diluvialler, og nederst igen Moræneler, til Dels kalkholdigt og uforvitret. Diluvialleret, der kan følges over en lang Strækning som et svagt bølget Baand i Klinten, er af en usædvanlig Beskaffenhed. Det indeholder nemlig temmelig mange Sten, enkelte endog af Størrelse som et Hoved, det gaar paa sine Steder uden Grænse over i Moræneleret og maa uden Tvivl betragtes som en subglacial Dannelse, der udgør en Del af Bundmorænen.

Hyppigt indeholder Moræneleret Indlag og Striber af Diluvialsand og Diluvialgrus. Disse Indlag kunne være løsrevne Partier fra Underlaget, ved Isens Bevægelse optagne og indæltede i dens Bundmoræne. Lagdelingen kan da enten være helt forsvunden, eller Lagene kunne være foldede og knækkede. Dette ses f. Eks. i den $4-5 \mathrm{~m}$. høje, af Søen renvaskede Morænelerklint i Vestenden af Svinø (L, M 3), og i den indtil $8 \mathrm{~m}$. høje Klint ved Sparretorn paa Nordsiden af Fyns Vig. Paa sidstnævnte Sted er der i Moræneleret indæltet større og mindre Partier af groft Grus, Sand hvori Lagdelingen delvis er bevaret, og af stenfrit Diluvialler, der er knust og omdannet til en ulagdelt Masse af smaa skarpkantede Lerbrokker med blanke Flader.

I mange Tilfælde ere dog Indlagene af lagdelt Materiale utvivlsomt aflejrede af Vandet under Isen oven paa Bundmoræenen, og senere dækkede af yngre Bundmoræne. Saadanne Lag have en betydelig Udstrækning og en Mægtighed af $1-2 \mathrm{~m}$; ; jævnlig vil man deri finde en næsten uforstyrret Lagdeling med diskordant Parallelstruktur, saaledes f. Eks. i Klinten Nordvest for Stendrup Hage. Omvendt kan man ogsaa i enkelte Profiler, i Reglen i Grusgrave, se én eller flere Bænke af Moræneler med en Mægtighed af 0,1-2,0 m. indlejrede konkordant i diluviale Sand- og Gruslag.

Ret ofte er Moræneleret bænket. Medens Lagdelingen i det ovenfor nævnte „stenede Diluvialler", en Overgangsform mellem Moræneler 

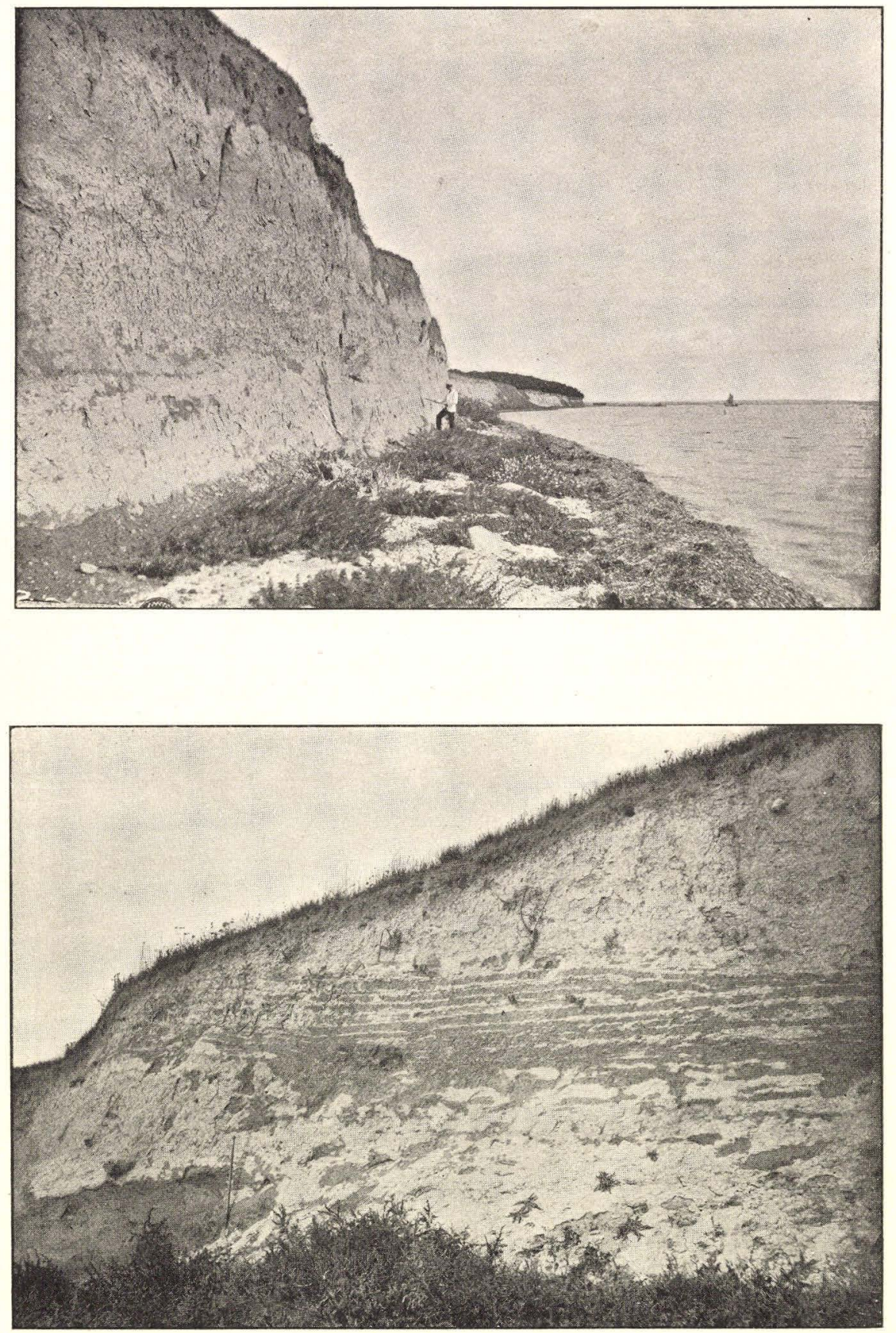

Fig. 6-7. Vekslende Lag af Moræneler og stenfrit Diluvialler. Klint SV. for Wedellsborg. 
og Diluvialler, maa anses for oprindelig og dannet ved Vandets Hjælp, er den grovere Bænkning i mange Tilfælde et Resultat af Landisens Bevægelse, idet de øvre Partier af den dejgagtige Bundmoræne føres med af Isen, medens de nedre Partier ligge stille. Bænkningen er som oftest tydeligst, hvor Bundmorænen har optaget meget Sand og Grus fra Undergrunden; i Morænesandet er Bænkning overordentlig almindelig, man kan næsten sige en Regel.

Flere Horizonter af Moræneler, adskilte ved mægtige Lag af fluvioglaciale Dannelser, kendes fra nogle faa Punkter, blandt andet fra Boringerne ved Wedellsborg og Frederikshøj Kro (XII og XX i Tillæget). Ved Wedellsborg fandtes i 8 Meters Dybde et $4,4 \mathrm{~m}$. mægtigt Lag Moræneler, der ikke er direkte sammenhængende med Overfladens Moræneler her omkring. Om det alligevel maa betragtes som i Tid sammenhørende med det øverste Moræneler omkring Wedellsborg, eller om det repræsenterer et tidligere Isdække over denne Egn, lader sig derimod ikke afgøre.

Ved Frederikshøj Kro fandtes i 18,7 Meters Dybde et 15, Meter mægtigt Lag "Mergel". Da denne Betegnelse anvendes for de øverste 3 Meter, der er Moræneler, maa det nederste Mergellag ogsaa antages at være en Morænedannelse. Den er skilt fra det øvre Moræneler ved de i denne Egn saa velkendte, udbredte og mægtige Gruslag, og maa derfor rimeligvis hidrøre fra et selvstændigt Fremstød af Indlandsisen, ældre end det, hvorved det øverste Moræneler aflejredes, men uden at der dog kan siges noget om Varigheden af det mellem de to Epoker liggende Tidsrum.

Vest for Stendrup By (N 3) iagttager man i den høje Skrænt paa Nordsiden af Solkjær Aa øverst Moræneler, det samme som dækker Overfladen af Plateauet her omkring; længere nede paa Skrænten findes et Bælte af Sand, der undertiden indeholder Lag af stenfrit Ler, og som kan følges Vest paa over en lang Strækning til henimod Ajtrup (O 3). Endelig findes i Klintens Fod igen Moræneler, paa hvis Overflade Vandet vælder ud og giver Anledning til en meget frodig Vegetation, paa flere Steder endog til Dannelsen af Tørvelag og Kildekalk. Noget Profil gennem denne Lagserie findes ikke, og Muligheden af falsk Paalejring ved Skred kan derfor ikke benægtes, men Paavisningen af den samme Lagfølge paa flere Steder, blandt andet ogsaa paa Sydsiden af Aaen, ved Bjært, samt de talrige Kildevæld der kommer frem paa Overfladen af det nederste Moræneler, tyder dog meget bestemt hen paa Tilværelsen af to forskellige, ved mægtige lagdelte Dannelser adskilte, Bundmoræner.

Lignende Lejringsforhold findes i Dalen ved Sest Aa, Vest for Gejlhave Gaard i Nærheden af Kortbladets Nordgrænse. Plateauet paa begge Sider af Dalen er delvis dækket af Moræneler, der ogsaa 
ses øverst i de stejle Skrænter ud mod Aaen. I et noget lavere Niveau kommer Diluvialsandet frem, nedenfor Geilhave Gaard paa en Strækning af over $1 \mathrm{~km}$., og i Dalens Bund finder man paa enkelte Steder atter Moræneler. Men heller ikke her findes noget Profil, der under ét viser den samlede Lagserie.

Paa Bogø i Lillebelt ere Lejringsforholdene ret ejendommelige. Den sydlige Del af Øen bestaar hovedsagelig af Diluvialsand af stor Mægtighed. Mod Nord og Øst overlejres Sandet af det „øvre“ Moræneler, der dækker Øens nordlige Del; mod Vest, hvor der i den indtil 5 m. høje Klint mellem Fyret og Vestermose findes Profiler i Diluvialsandet, finder man under Sandet atter Moræneler. Dette „nedre“ Moræneler kan fra Klintens Nordende følges ud under Vestermose, hvor det - da Diluvialsandet her kiler ud og forsvinder - direkte paalejres af og smelter sammen med det „øvre“ Moræneler, der fra Bakkerne mod Nord og Øst ligeledes strækker sig ud under Tørven. Da det omtalte Parti Diluvialsand har saa stor Udstrækning og Mægtighed, kan det næppe betragtes som et Indlag i Bundmorænen; der er større Sandsynlighed for, at de to Morænebænke repræsentere to forskellige Fremstød af Indlandsisen.

Selv om disse Iagttagelser ere faa og spredte og ikke afgive noget virkeligt Bevis, maa der dog siges at være meget stor Sandsynlighed for, at man indenfor Kortbladsomraadet vil kunne finde to Morænehorizonter, en ældre og en yngre, i Reglen adskilte ved lagdelt Diluvium. Hvor de to Moræner hvile direkte paa hinanden, vil man næppe ved Boring og sjældent i Profiler have Midler til at sondre imellem dem; og lige saavel som det øverste Moræneler mangler paa talrige Steder, maa det samme kunne være Tilfældet med en ældre Moræne.

Den Mulighed er heller ikke udelukket, at Overfladens Moræeneler kunde være af forskellig Alder paa forskellige Steder indenfor Kortbladsomraadet, f. Eks. Øst og Vest for én af de Morænelinier, som senere skulle omtales. For af Hensyn hertil at kunne drage Sammenligninger mellem Prøver af Moræneler fra forskellige Dele af Omraadet og desuden mellem disse og Prøver fra andre Egne af Landet, er der foretaget en Række Stentællinger efter den i Beskrivelsen til Kortbladet Hindsholm angivne Metode ${ }^{1}$ ); der anvendtes overalt $10 \mathrm{Kg}$. Moræneler (eller Morænesand), Stenene heri vaskedes ud, og Tællingen foretoges paa de Sten, der vare større end c. $6 \mathrm{~mm}$. og mindre end et Hønseæg. Resultaterne findes i omstaaende Tabeller (Side 29-31). Hvad der synes at have haft Betydning andre Steder og

1) N. V. Ussing og Victor Madsen: Kortbladet Hindsholm. D. G. U. I. Række, Nr. 2. Kjøbenhavn 1897. Side 23. 


\section{Stentællinger.}

(Sten af over $6 \mathrm{~mm}$. Diameter).

\begin{tabular}{|c|c|c|c|c|c|c|c|c|c|c|c|c|c|c|c|c|c|}
\hline & 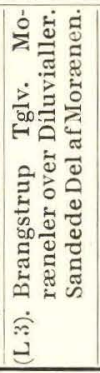 & 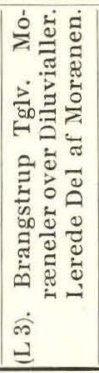 & 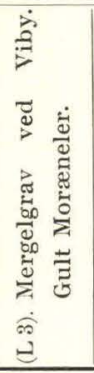 & 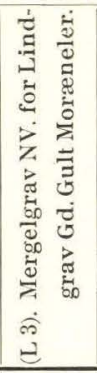 & 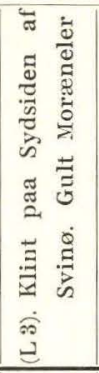 & 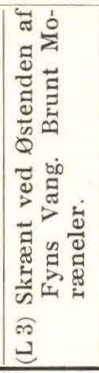 & 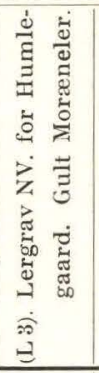 & 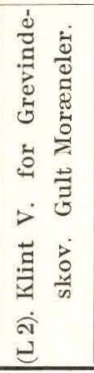 & 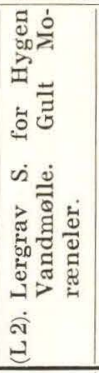 & 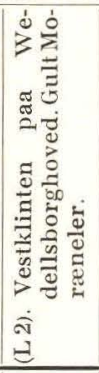 & 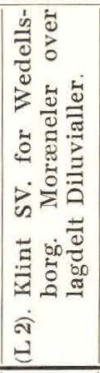 & 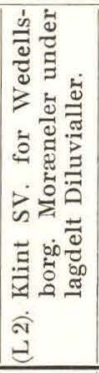 & 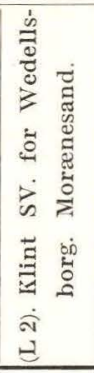 & 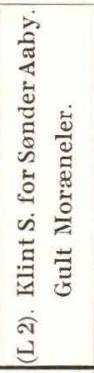 & 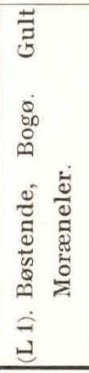 & 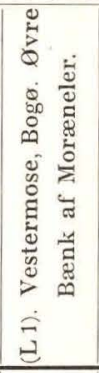 & 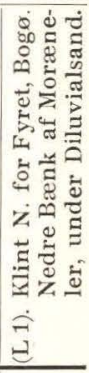 \\
\hline $\begin{array}{l}\text { Prøvens Vægt i Gram. } \\
\text { Stenenes Vægt i Gram. } \\
\text { Stenenes Antal . . . . . . }\end{array}$ & $\begin{array}{r}10000 \\
719 \\
949\end{array}$ & $\begin{array}{r}10000 \\
363 \\
498\end{array}$ & $\begin{array}{r}10000 \\
427 \\
550\end{array}$ & $\begin{array}{r}10000 \\
448 \\
551\end{array}$ & $\begin{array}{r}10000 \\
527 \\
330\end{array}$ & $\begin{array}{r}10000 \\
403 \\
550\end{array}$ & $\begin{array}{r}10000 \\
330 \\
588\end{array}$ & $\begin{array}{r}10000 \\
283 \\
148\end{array}$ & $\begin{array}{r}10000 \\
180 \\
116\end{array}$ & $\begin{array}{r}10000 \\
150 \\
142\end{array}$ & $\begin{array}{r}10000 \\
165 \\
139\end{array}$ & $\begin{array}{r}10000 \\
364 \\
302\end{array}$ & $\begin{array}{r}10000 \\
380 \\
315\end{array}$ & $\begin{array}{r}10000 \\
390 \\
247\end{array}$ & $\begin{array}{r}10000 \\
88 \\
49\end{array}$ & $\begin{array}{r}10000 \\
265 \\
179\end{array}$ & $\begin{array}{r}10000 \\
273 \\
166\end{array}$ \\
\hline 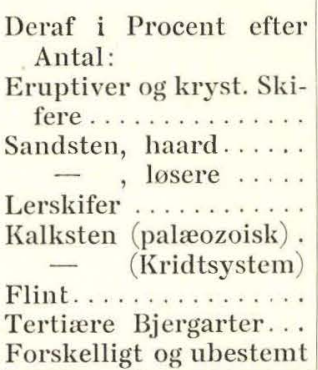 & $\begin{array}{r}35,5 \\
4,6 \\
9,3 \\
0,9 \\
14,8 \\
12,1 \\
22,5 \\
0,3\end{array}$ & $\begin{array}{r}32,5 \\
3,6 \\
11,6 \\
2,2 \\
13,5 \\
15,1 \\
21,3 \\
\\
0,2\end{array}$ & $\begin{array}{r}31,2 \\
3,5 \\
10,8 \\
1,8 \\
13,8 \\
12,4 \\
26,2 \\
0,3\end{array}$ & $\begin{array}{r}36,6 \\
3,3 \\
9,3 \\
2,5 \\
3,6 \\
5,1 \\
37,2 \\
2,4\end{array}$ & $\begin{array}{r}36,7 \\
3,0 \\
17,3 \\
3,0 \\
0,3\end{array}$ & $\begin{array}{r}42,5 \\
6,9 \\
20,8 \\
1,2\end{array}$ & $\begin{array}{r}35,0 \\
2,0 \\
8,2 \\
2,7 \\
12,1 \\
11,2 \\
28,3 \\
0,5\end{array}$ & $\begin{array}{r}27,7 \\
6,7 \\
11,5 \\
0,6 \\
14,2 \\
14,3 \\
25,0\end{array}$ & $\begin{array}{r}25,0 \\
6,8 \\
12,2 \\
5,2 \\
15,5 \\
5,2 \\
28,4 \\
1,7\end{array}$ & $\begin{array}{r}42,9 \\
3,5 \\
10,6 \\
1,4 \\
\\
0,7 \\
40,2 \\
0,7\end{array}$ & $\begin{array}{r}30,0 \\
5,1 \\
7,2 \\
2,2 \\
15,8 \\
11,6 \\
26,7 \\
1,4\end{array}$ & $\begin{array}{r}23,2 \\
2,3 \\
9,3 \\
3,3 \\
11,9 \\
19,2 \\
29,5 \\
1,3\end{array}$ & $\begin{array}{r}25,0 \\
7,9 \\
2,3 \\
0,6 \\
9,2 \\
21,6 \\
32,4 \\
1,0\end{array}$ & $\begin{array}{r}31,6 \\
4,0 \\
6,5 \\
1,2 \\
9,7 \\
17,8 \\
29,2\end{array}$ & $\begin{array}{r}26,5 \\
6,1 \\
4,1 \\
\\
8,2 \\
14,3 \\
40,8\end{array}$ & $\begin{array}{r}33,6 \\
11,2 \\
9,5 \\
1,6\end{array}$ & $\begin{array}{r}26,5 \\
3,6 \\
4,2 \\
5,4 \\
15,7 \\
8,1 \\
36,2\end{array}$ \\
\hline $\begin{array}{l}\text { Procenttal for Flint, di- } \\
\text { videret med Procent- } \\
\text { tallet for Eruptiver } \\
\text { og kryst. Skifere... }\end{array}$ & 0,63 & 0,65 & 0,88 & 1,02 & $1, \cap 5$ & 0,64 & 0,81 & 0,90 & 1,14 & 0,94 & $0,4_{0}$ & 1,27 & 1,29 & 0,92 & 1,54 & 0,93 & 1,36 \\
\hline
\end{tabular}




\section{Stentællinger.}

(Sten af over $6 \mathrm{~mm}$ Diameter)

\begin{tabular}{|c|c|c|c|c|c|c|c|c|c|c|c|c|c|c|c|c|c|c|}
\hline . & 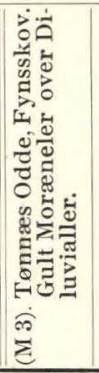 & 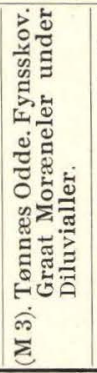 & 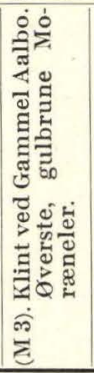 & 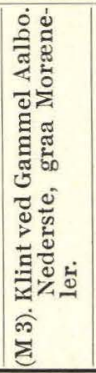 & 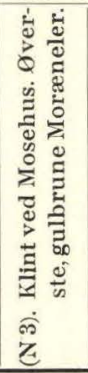 & 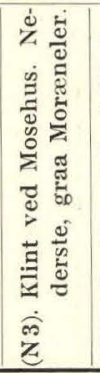 & 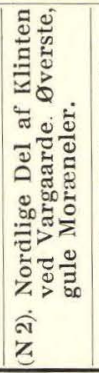 & 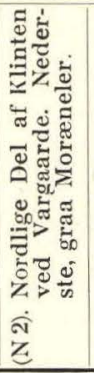 & 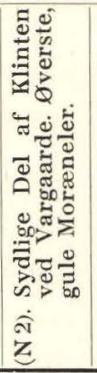 & 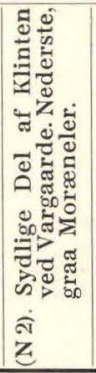 & 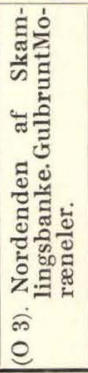 & 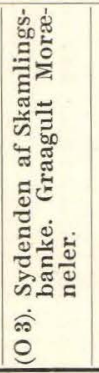 & 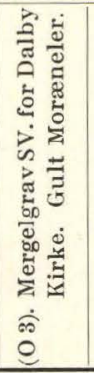 & 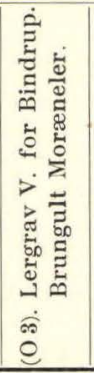 & 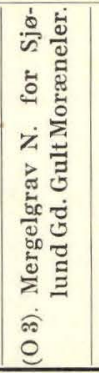 & 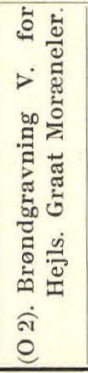 & 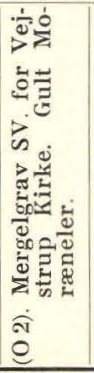 & 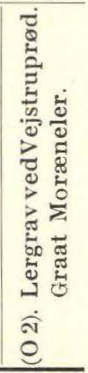 \\
\hline $\begin{array}{l}\text { Prøvens Vægt i Gram .. } \\
\text { Stenenes Vægt i Gram.. } \\
\text { Stenenes Antal........ }\end{array}$ & $\begin{array}{r}10000 \\
165 \\
166 \\
\end{array}$ & $\begin{array}{r}10000 \\
257 \\
196\end{array}$ & $\begin{array}{r}10000 \\
280 \\
195 \\
\end{array}$ & $\begin{array}{r}10000 \\
186 \\
137 \\
\end{array}$ & $\begin{array}{r}10000 \\
181 \\
158 \\
\end{array}$ & $\begin{array}{r}10000 \\
114 \\
116 \\
\end{array}$ & $\begin{array}{r}10000 \\
329 \\
497 \\
\end{array}$ & $\begin{array}{r}10000 \\
450 \\
676 \\
\end{array}$ & $\begin{array}{r}10000 \\
233 \\
313\end{array}$ & $\begin{array}{r}10000 \\
424 \\
713 \\
\end{array}$ & $\begin{array}{r}10000 \\
197 \\
244 \\
\end{array}$ & $\begin{array}{r}10000 \\
276 \\
280 \\
\end{array}$ & $\begin{array}{r}10000 \\
328 \\
248\end{array}$ & $\begin{array}{r}10000 \\
150 \\
116 \\
\end{array}$ & $\begin{array}{r}10000 \\
102 \\
112 \\
\end{array}$ & $\begin{array}{r}10000 \\
137 \\
154 \\
\end{array}$ & $\begin{array}{r}10000 \\
259 \\
218\end{array}$ & $\begin{array}{r}10000 \\
166 \\
167 \\
\end{array}$ \\
\hline 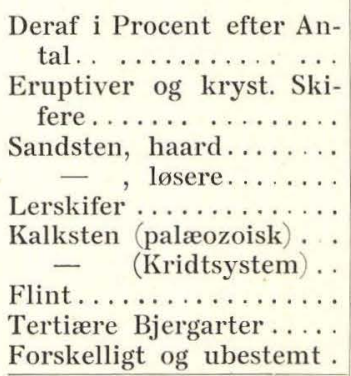 & $\begin{array}{r}25,3 \\
4,2 \\
2,4 \\
1,2 \\
10,2 \\
12,1 \\
41,6 \\
3,0\end{array}$ & $\begin{array}{r}31,6 \\
6,1 \\
6,1 \\
1,0 \\
10,2 \\
7,3 \\
37,7\end{array}$ & $\begin{array}{r}32,8 \\
6,7 \\
5,1 \\
0,5 \\
9,8 \\
9,7 \\
31,8 \\
3,6\end{array}$ & $\begin{array}{r}37,9 \\
6,6 \\
2.9 \\
0,7 \\
16,0 \\
5,2 \\
29,2 \\
1,5\end{array}$ & $\begin{array}{r}33,5 \\
3,8 \\
3,8 \\
0,6 \\
10,8 \\
7,6 \\
36,1 \\
3,8\end{array}$ & $\begin{array}{r}29,3 \\
10,3 \\
2,6 \\
\\
12,1 \\
1,7 \\
42,3 \\
1,7\end{array}$ & $\begin{array}{r}31,2 \\
5,8 \\
4,8 \\
0,8 \\
12,7 \\
9,6 \\
31,2 \\
3,4 \\
0,5\end{array}$ & $\begin{array}{r}35,8 \\
4,9 \\
5,2 \\
1,2 \\
18,5 \\
6,1 \\
17,9 \\
10,3 \\
0,1\end{array}$ & $\begin{array}{r}45,7 \\
4,8 \\
7,7 \\
1,3 \\
\\
1,2 \\
37,4 \\
1,9\end{array}$ & $\begin{array}{r}33,7 \\
3,2 \\
5,9 \\
2,3 \\
18,9 \\
10,5 \\
16,7 \\
8,3 \\
0,5\end{array}$ & $\begin{array}{r}24,6 \\
4,9 \\
1,2 \\
0,8 \\
14,4 \\
18,4 \\
33,6 \\
2,1\end{array}$ & $\begin{array}{r}31,1 \\
7,5 \\
3,6 \\
2,1 \\
11,1 \\
13,9 \\
27,5 \\
3,2\end{array}$ & $\begin{array}{r}39,1 \\
4,4 \\
2,0 \\
0,4 \\
5,3 \\
2,0 \\
33,5 \\
12,9 \\
0,4\end{array}$ & $\begin{array}{r}40,5 \\
6,9 \\
3,5\end{array}$ & $\begin{array}{r}44,6 \\
2,7 \\
1,8 \\
3,6 \\
7,1 \\
8,9 \\
29,5 \\
1,8\end{array}$ & $\begin{array}{r}32,5 \\
5,8 \\
7,8 \\
0,6 \\
13,0 \\
8,4 \\
16,2 \\
14,3 \\
1,4\end{array}$ & $\begin{array}{r}45,4 \\
9,2 \\
5,5 \\
2,3 \\
8,7 \\
6,4 \\
20,6 \\
1,9\end{array}$ & $\begin{array}{r}31,7 \\
9,0 \\
1,8 \\
\\
10,2 \\
8,4 \\
19,8 \\
18,5 \\
0,6\end{array}$ \\
\hline $\begin{array}{r}\text { Procenttal for Flint, divi- } \\
\text { deret med Procenttallet } \\
\text { for Eruptiver og kryst. } \\
\text { Skifere............. }\end{array}$ & 1,61 & 1,07 & 0,96 & 0,77 & 1,07 & 1,44 & 1,00 & 0,50 & 0,82 & 0,49 & 1,36 & 0,88 & 0,85 & 1,12 & 0,67 & 0,50 & 0,45 & 0,62 \\
\hline
\end{tabular}




\section{Stentællinger.}

(Sten af over $6 \mathrm{~mm}$. Diameter).

\begin{tabular}{|c|c|c|c|c|c|}
\hline & 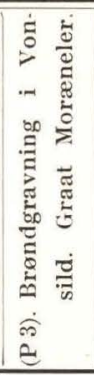 & 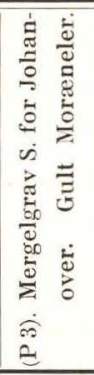 & 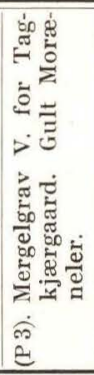 & 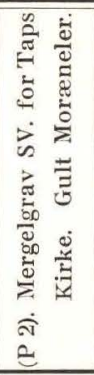 & 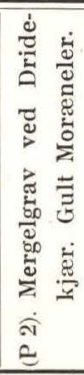 \\
\hline Prøvens Vægt i Gram & 10000 & 10000 & 10000 & 10000 & 10000 \\
\hline Stenenes Væagt i Gram & 267 & 167 & 487 & 168 & 444 \\
\hline Stenenes Antal ...... & 181 & 154 & 324 & 115 & 222 \\
\hline Deraf i Procent efter Antal: & & & & & \\
\hline Eruptiver og kryst. Skifere .. & 37,6 & 31,1 & 30,3 & 49,5 & 19,8 \\
\hline Sandsten, haard .......... & 3,9 & 8,5 & 4 , & 5,2 & 11,7 \\
\hline - , løsere $\ldots \ldots \ldots \ldots$ & 2,8 & 5,2 & 0,9 & 5,2 & 3,6 \\
\hline $\begin{array}{l}\text { Lerskiter ............ } \\
\text { Kalksten (palæozoisk) }\end{array}$ & 14,3 & & & & \\
\hline - (Kridtsystem) & 7,2 & & & & 0,9 \\
\hline Flint . . . . . . & 27,6 & 46,8 & 50,9 & 35,7 & 59,9 \\
\hline Tertiære Bjergarter & 4,9 & 5,8 & 13,3 & 4,4 & 4,1 \\
\hline Forskelligt og ubestemt ..... & 1,7 & 2,6 & & & \\
\hline $\begin{array}{l}\text { Procenttallet for Flint, divi- } \\
\text { deret med Procenttallet for } \\
\text { Eruptiver og kryst. Skifere }\end{array}$ & 0,64 & 1,50 & 1,58 & 0,73 & 3,03 \\
\hline
\end{tabular}

kunnet fore til en Sondring mellem Moræneler af forskellig Alder og Udbredelse, nemlig Mængdeforholdet (efter Antal) mellem Flint og Eruptiver, vil næppe faa synderlig Betydning paa Kortbladet Skamlingsbanke. Tallene variere her saa stærkt, selv indenfor smaa Omraader, og uden at der kan paavises nogen Grund dertil hverken i Overfladeformen eller i Lejringsforholdene. Ogsaa hvor der i samme Klint er taget flere Prøver - af det øverste gulbrune og det nederste graa Moræneler - svinge Tallene stærkt, og saaledes at det snart er det kalkholdige, snart det kalkfri Ler, der indeholder mest Flint i Forhold til Eruptiverne. Forholdstallene ere for det fynske Moræneler for største Delen under 1,00. Dette er f. Eks. Tilfældet med det øverste Moræneler i Klinten ved Wedellsborg (L 2), hvorimod det under Diluvialleret liggende Moræneler og Morænesand vise højere Kvotienter, 1,27-1,29. Paa Bogø svinge Tallene for Overfladens Moræneler fra 0,93 til 1,54, medens det formodede „nedre“ Moræneler indtager en Middelstilling. Ude paa Fynsskov (M 3) viser Moræneleret nærmest Overfladen et saa højt Forholdstal som 1,64, medens Moræneleret i Klintens Fod kun er er 1,07. Vest for Lillebelt er 
Forholdet i Klinten ved Mosehus (N 3) netop det omvendte. I Klinten ved Vargaarde (N 2) viser Leret nærmest Overfladen omtrent dobbelt saa store Kvotienter som Leret i Klintens Fod. Et lignende Forhold findes mellem det utvivlsomt samtidige Moræneler i Nordenden og i Sydenden af Skamlingsbanke. Vest for Skamlingsbanke veksle Forholdstallene for Overfladens Moræneler fra 0,45 til 1,58 og stiger endog nær Kortbladets Sydvesthjørne (P 2) til den usædvanlige Størrelse af 3,03 .

Senere, naar de tilstødende Landsdele ere undersøgte paa samme Maade, er det $\operatorname{dog}$ muligt, at man vil kunne drage Slutninger af disse Stentællinger.

Moræneleret har i forrige Aarhundrede haft en overordentlig stor Anvendelse som Mergel; de talrige tilgroede eller vandfyldte Mergelgrave, som ses overalt paa Markerne, vidne derom. Ogsaa som Teglværksler har det været anvendt, endog fra meget gammel Tid. Paa Voldstedet Vest for Gamborg findes Mursten brændte af Moræneler (Slottet "Gamleborrig" omtales i det trettende Aarhundrede og spillede senere en Rolle under Valdemar Atterdag). Nu anvendes Moræneleret kun i enkelte smaa, gamle Teglovne og til lokalt Brug.

\section{Morænegrus og Stenet Sand.}

Morænegrus af typisk Udseende optræder kun paa faa Steder indenfor Kortbladsomraadet og kun over smaa Arealer. Øst for Lillebelt findes paa Svinø det bedste og i denne Egn det eneste Profil i denne Aflejring. I en $3 \mathrm{~m}$. høj Væg i en Grusgrav umiddelbart ved Landevejen ses den tæet og haardtpakkede Masse af store og smaa Sten, ofte af meget kantede Former og i mange Tilfæelde isskurede. Stenene findes i alle mulige Stillinger, Mellemrummene ere udfyldte med leret Grus, pletvis Moræneler; enkelte Steder kan der forekomme smaa Indlag af lyst Grus, hvori der kan spores en svag Lagdeling.

Paa den jydske Del af Kortbladet er det typiske Morænegrus lige saa sparsomt repræsenteret. Et smukt Profil findes i en stor Grusgrav mellem Grundinghoved og Sjølund (O 3); i den 6 m. høje Væg ses øverst fedt, gulbrunt Moræneler med en Mægtighed, der veksler fra 1 til 2 , undertiden $3 \mathrm{~m}$. Derunder findes $\mathrm{i}$ en Del af Profilet et $1 \mathrm{~m}$. mægtigt Lag af diskordant og bølget lagdelt, groft Sand og fint Grus med indtil ægstore Sten. Under dette Lag ses en stærkt sammenæltet Masse af groft, rullet Grus, Sandstriber og leret Morænegrus med indtil hovedstore Sten, ialt $1-2 \mathrm{~m}$. Ved et $2 \mathrm{dcm}$. tykt Sandlag skilles denne Grusmasse fra en $1-1 \frac{1}{2}$ m. mægtig, meget haard Bænk af fast sammenpakket Grus og Sten, hvor mange 
af Stenene ere af langt over et Hoveds Størrelse. Da dette Lag yderligere er gennemtrængt og sammenkittet af Jernilter, er det meget vanskeligt at bryde. I Gravens Bund findes lyst, groft, horizontalt lagdelt Diluvialsand. Hele Lagserien over Diluvialsandet har en udpræget Bundmoræne-Karakter; det lerede, stærkt komprimerede Grus, de talrige isskurede Sten og den gentagne Vekslen mellem uforandret Bundmoræne og Morænemateriale, der er paavirket og delvis omlejret af Vand, viser altsammen hen til en subglacial Aflejring.

Et Profil, der i meget minder om Grusgraven ved Grundinghoved, findes ved $Ø d i s$, Sydvest for Fovslet, i Kortets Vestrand. Paa Nordsiden af Dalen ses i en c. $5 \mathrm{~m}$. høj Grusvæg nederst lagdelt Sand og Grus af meget leret Beskaffenhed. Dels som linseformede Indlag, dels som Bænke mellem Lagene findes grusholdigt, magert Moræneler; ofte gaar dette uden Grænse over i det omgivende, lerfyldte Grus. Den øverste Trediedel af Profilet er en uregelmæssig Blanding af leret Sand med mange Sten, Moræneler og Morænegrus, der i Profilets vestlige Del er presset ned i de underliggende, af Smeltevandet paavirkede Lag.

At Morænegrus findes paa adskillig flere Steder end angivet paa det geologiske Kort, er utvivlsomt, men kun ved Hjælp af Profiler er det muligt med Sikkerhed at afgøre, om man har med den typiske Aflejring at gøre. Hvor Overfladen er rig paa Sten, og dette er hyppigt Tilfældet, vil det som oftest vise sig at skyldes en Aflejring af en ganske anden Karakter end det ovenfor beskrevne Morænegrus, nemlig et Overfladelag, der savner en subglacial Dannelses Ejendommeligheder, og som ikke direkte har noget med Bundmorænen at gøre.

Denne Overfladedannelse kan enten vise sig som en mere eller mindre tæt Bestrøning af store Sten umiddelbart oven paa Moræneleret eller Diluvialsandet, eller som et Sandlag, sjældent mere end $1-1^{1} / 2 \mathrm{~m}$. mægtigt, hvori store og smaa Sten ligge spredt uden Orden. Dette Sand, "stenet Sand", viser ingen Lagdeling eller Sortering, det er derfor ikke aflejret af Vandet. I Udseende minder det om en Morænedannelse, hvor Sand og Sten af meget forskellig Vægt og Kornstørrelse ligger uordentligt mellem hinanden; men det er altid kalkfrit, og Indholdet af Ler og andre Partikler mindre end 0,01 mm. er yderst ringe. Dette stenede Sand bør vistnok opfattes som en Aflejring, der er opstaaet af det i Isens øvre Partier og paa dens Overflade liggende Morænemateriale, hvor Kalksten og andre bløde Stenarter ere sprængte og smuldrede ved de stærke Temperaturforandringer, og hvor samtidig Vinden og Smeltevandet har bortført de fineste Partikler. Ved Isens fuldstændige Bortsmeltning aflejredes 
denne stenede Sand- og Grusmasse, der var meget ujævnt fordelt over Isen, som et tyndt Dække over de ældre, glaciale Lag.

Stenet Sand som Dække over Moræneler kunde vistnok indlægges paa det geologiske Kort over meget store Arealer, men som oftest er Laget af saa ringe Mægtighed, at det vanskeligt lader sig adskille fra det løse, sandede og muldede Lag, hvortil Morænelerets øverste Del kan være omdannet dels ved Udvaskning dels ved Vegetationens og Opdyrkningens Indflydelse. De Steder, hvor det stenede Sand har en saadan Beskaffenhed og Mægtighed, at det absolut bør udskilles fra det underliggende Moræneler som en selvstændig Aflejring, have ikke nogen stor Udstrækning. Moræenematerialet ovenpaa og i Isens øverste Partier maa da væsentlig have bestaaet af spredte Sten; saadanne findes ofte i Mængde paa Morænelerets Overflade og maa $\mathrm{i}$ tidligere Tid have været langt almindeligere end nu.

En Bestrøning af store Sten paa Overfladen er sjælden paa den fynske Del af Kortbladsomraadet, og ses i alt Fald kun paa faa Steder i Nutiden. Vest for Lillebelt ere Stenbestrøninger mere almindelige, dog har ogsaa her den stigende Efterspørgsel efter Sten til Bygnings- og Vejmateriale bevirket, at ikke alene Markerne ere rensede for store Sten, men at ogsaa Stenbunker og Stengærder forsvinde mere og mere. Et Strøg, hvor man endnu pletvis kan se de store Sten liggende temmelig tæt paa Overfladen, findes Vest for Svanmose (P 3), hvor det løber fra Nord gennem Fovslet Skov og videre mod Syd og Sydvest til henimod den ovenfor beskrevne Grav i Morænegruset ved Ødis.

Paa Steder, hvor Landisen ikke har aflejret nogen Bundmoræne, men har bevæget sig direkte hen over Undergrunden, der i Reglen bestod af fluvioglacialt Sand og Grus, har den utvivlsomt optaget en Del af det underliggende Materiale i sig. Under Afsmeltningen er denne Indremoræne (for en Del ogsaa Overflademoræne) bleven blandet med de større Sten, som ere medførte i eller oven paa Isen, og aflejredes da som en Kappe af "stenet Sand" umiddelbart over de aldre glaciale Lag.

Stenet Sand over Diluvialsand forekommer meget almindeligt og lader sig let paavise, selv om Laget er tyndt, idet den underliggende Dannelse, Diluvialsandet, som oftest er stenfri og kun i yderst faa Tilfælde indeholder saa store Sten, som man jævnlig finder i det stenede Sand. Undertiden kan det stenede Overfladelag være fremkommet ved Bortskylning og Bortblæsning af Sandet, hvorved Stenene ere blevne tilbage; i saadanne Tilfælde ere Stenene som Regel smaa, have omtrent samme Størrelse og ligge samlede i et enkelt Lag paa eller i Sandet. 
Ved den geologiske Kortlægning kan det ikke altid afgøres, om det foreliggende Sand er "stenet Sand" eller kalkfrit, grusholdigt Diluvialsand. Hvor Profiler mangle, vil derfor Fravæerelsen eller Forekomsten af større og mindre erratiske Sten, der ligge spredte paa Markens Overflade (eller ere samlede sammen i Stengærder), være det eneste Kendetegn paa, om Diluvialsandet gaar i Dagen, eller om der over dette ligger en ikke fluvioglacial Aflejring, en Morænerest.

Medens Morænegruset som Jordart spiller en meget ringe Rolle, har det derimod i teknisk Henseende stor Værdi ved sit Indhold af Sten, der oftest ere af en saadan Størrelse, at de kunne anvendes til Bygningssten eller Vejmateriale. Det stenede Sand af almindelig Type har kun Betydning for Agerbruget, men danner som Regel en mindre værdifuld Jordbund. Paa Grund af sin løse Beskaffenhed kan det ikke tilbageholde Fugtighed, men udtørres let; og da det ved sin Dannelsesmaade har mistet største Delen af de finere Bestanddele og let forvitrende Bjergarter, er det en temmelig mager Jordbund, i Sardeleshed paa Steder, hvor Mægtigheden er saa stor, at Underlaget ikke faar nogen nævneværdig Indflydelse paa Vegetationen.

\section{De løse Blokke.}

Blandt de løse Blokke, der findes indenfor Kortbladsomraadet, saavel i Moræneaflejringerne som i det lagdelte Diluvialgrus ere danske Bjergarter som f. Eks. Flint og Kalksten fra Nyere Kridt til Stede i stor Mængde. De Stenarter, der ere tilførte ude fra, og hvis Hjemsted med nogenlunde Sikkerhed kan bestemmes, hidrøre for den langt overvejende Dels Vedkommende fra Østersøegnene. Saadanne Blokke kunne uden Vanskelighed samles næsten overalt og meddele Overfladens glaciale Lag et utvivlsomt og meget iøjnefaldende Præg af baltisk Oprindelse. Desuden findes der, hovedsagelig blandt de krystallinske Bjergarter, enkelte, hvis Hjemsted maa søges i og omkring Kristianiafjord, men deres Antal er meget ringe og aldeles forsvindende i Forhold til de baltiske Blokke.

\section{a. Krystallinske Bjergarter.}

De norske Bjergarter, blandt hvilke den let kendelige Rhombeporfyr er den hyppigste, forekomme meget sjældent paa den fynske Del af Kortbladsomraadet. Rhombeporfyrer ere dog fundne ved Kysterne, saaledes i Strandgrus paa Fynsskov og ved Wedellsborg. Paa Øerne i Lillebelt ere de hyppigere; der er fundet 2 Stk. paa Bogø, 1 paa Egholm, 1 paa Bastholm, 1 paa Thorø og 4 paa Brandsø. De ere ganske vist paa disse Steder samlede i Strandgrus, men der 
kan ikke være Tale om andet end, at de hidrøre fra Øernes egne glaciale Lag.

Vest for Lillebelt ere de norske Stenarter hyppigere, men synes at være ret ujæunt fordelte, saaledes at de i enkelte Egne ere yderst sjældne, medens man paa andre Strøg kan finde dem i de fleste større Samlinger af Sten. Paa et enkelt Sted, paa Stranden under den 10-13 m. høje Morænelerklint Nord for Vargaarde (se Fig. 5, Side 21), hvor der gentagne Gange er foretaget Indsamlinger af løse Blokke, er der ialt fundet 25 Stykker Rhombeporfyrer, af meget forskelligt Udseende, og desuden enkelte norske Syeniter og Tuffer. Forholdene paa Stedet vise, at der ikke langs Stranden sker nogen Tilførsel af Sten fra andre Steder, men at samtlige Blokke maa være udvaskede af Morænelerklinten. Selv om Antallet af norske Bjergarter fra dette Sted er temmelig stort, er det dog forsvindende i Forhold til Antallet af de dér forekommende baltiske Blokke.

Paa Kortbladets øvrige Del er der yderligere samlet omtrent et halvt Hundrede Blokke af Rhombeporfyr, fordelte paa en Mængde Lokaliteter. Naar man ser bort fra Stranden ved Vargaarde, ere Rhombeporfyrerne sjældne i hele den østlige og nordøstlige Del af det jydske Omraade. Vest for Skamlingsbanke er der fundet en Del i Egnen omkring Aastorp, (hvor Diluvialgruset er almindeligt og paa flere Steder kommer frem til Overfladen), men først Vest for Kolding-Haderslev Landevej (paa P 3 og P 2) ere de samlede i større Antal og paa en Mrengde Steder.

De øvrige krystallinske Bjergarter, hvis Hjemsted kan bestemmes, stamme som nævnt dels fra Dalarne, dels fra Østersøens Bund eller Kystegne. De findes meget almindeligt og kunne samles næsten overalt, uden at der synes at være nogen Forskel paa Kortbladets østlige og vestlige Del. Som Eksempel kan nævnes Forekomsten ved Vargaarde Klint (Fig. 5), hvor disse Stenarter ses i Hundredvis. Her er saaledes Ålands-Granit overordentlig almindelig; foruden typiske Stykker findes talrige Overgangsformer saavel til Rapakivi som til Ålands-Kvartsporfyr. Den typiske Rapakivi er noget sjældnere, derimod forekommer Alands-Kvartsporfyr med de store, afrundede Kvartskorn meget hyppigt. Den brune Østersø-Kvartsporfyr er ikke saa almindelig; noget hyppigere er den røde Østersø-Kvartsporfyr med den røde Grundmasse og de oftest skarpkantede Kvartskorn (i tidligere danske Kortbladsbeskrivelser kaldet Rødø-Kvartsporfyr). Porfyrer fra Dalarne findes ligeledes i meget stort Antal; hyppigst er Bredvadporfyr og Grönklittporfyr. Bjergarter fra Småland er ikke sjældne; der findes saavel Graniter som den let kendelige Påskallavikporfyr. Af Basalter forekomme adskillige af samme Udseende som de skaanske Basalter. 


\section{b. Sedimentære Bjergarter.}

Ser man bort fra de i Grusgravene saa hyppigt forekommende Forsteninger fra den danske Kridtformation, ere fossilførende Blokke temmelig sjældne indenfor Kortbladsomraadet. Fra et enkelt Sted - nemlig Strandbredden under Morænelerklinten Nord for Vargaarde (N2) - , hvor der ved gentagne Besøg er foretaget en omhyggelig Indsamling, er der dog hjembragt et ret anseligt Antal.

Dr. phil. K. A. Grönwall meddeler følgende om disse Blokke:

\section{Silur.}

\section{Nedre Silur.}

„a) Ortocerkalk. Af rød Ortocerkalk er der hjembragt tre Stykker, et af en rød- og gulflammet Stenart, som rimeligvis stammer fra Ølands nedre røde Ortocerkalk. To Blokke af en rent mørkerød Kalksten stamme derimod sandsynligvis fra den øvre røde Ortocerkalk paa Øland.

b) Østersøkalk. Af denne Stenart, i udvidet Betydning, foreligger 3 Stykker. Af disse er det ene en Wesenbergerkalk af den gullig-graa tætte Stenart, som ligner den litografiske Skifer, og de to andre Palæoporellakalkstene. Den ene af disse er en lysegraa Stenart med noget krystallinsk Kalkspat og talrige Palæoporeller; den anden er graa med rødlige Partier og ligeledes en Del krystallinsk Kalkspat; foruden Palæoporeller indeholder den ogsaa andre Kalkalger og Brakiopoder samt Hovedet af en Illonus.

\section{2. Øvre Silur.}

a) Graptolitkalksten. Af de Stenarter, som sammenfattes herunder, findes to Stykker, der begge kun indeholde ubetydelige Fragmenter af Graptoliter, men i øvrigt ere fuldkommen overensstemmende med Typerne for denne Stenart. Det ene er en graa Kalksten med Fragmenter af Graptoliter og Ortocerer. Den anden er grønlig-graa og rig paa Forsteninger, særlig Brakiopoder, Glassia obovata Sow. og Rhynchonella trilobula F. Roem. (= Pentamerus trilobatus F. Roem.), Ortocerer og Snegle, hvorimellem Pleurotomaria extensa F. Roem. samt Fragmenter af Calymmene sp.

b) Beyrichiakalk og Stenarter, som til Dels have Tilknytning til denne, ere de hyppigste oversiluriske Blokke, i det 10 Beyrichia-

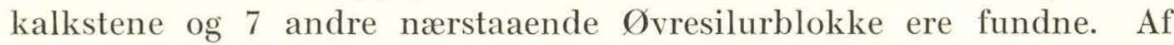
Beyrichiakalkblokkene kunne 3 Stykker bestemt henføres til Osel som Hjemsted.

En Blok af graa, noget krystallinsk Kalksten med gulbrune 
Ostrakodskaller særlig hyppige paa Lagdelingsfladerne indeholder: Chonetes striatella (hyppig), Beyrichia tuberculata (meget hyppig), B. Salteriana (2 Eks.), Kloedenia Wilckensiana (hyppig) og Aparchites oblongus (enkelte Ekspl.).

I en Blok af graa Kalksten, hvor tæt Kalksten veksler med Lag af graa Mergel, findes af Forsteninger talrige Fragmenter af Brakiopoder og Ostrakoder med sorte eller mørkebrune Skaller. Beyr. tuberculata, som forekommer i flere Varieteter, er overvejende; af Beyr. Salteriana og Aparchites oblongus findes kun enkelte Ekspl.

En graa Kalksten dels krystallinsk, dels tæt, indeholder talrige Forsteninger, der ere samlede paa enkelte Steder i Stenarten. Hyppigst er Beyr. tuberculata (i flere Former), desuden findes Pholidops antiquus, Chonetes striatella, Rhynchonella bidentata, Beyr. Buchiana, B. nodulosa? og Klodenia Wilckensiana samt Orthoceras sp.

Tre Blokke af Beyrichiakalk maa anses for at stamme tra Skaane. En Blok af tæt graa Kalksten, der danner en i det højeste $3 \mathrm{~cm}$. tyk, delvis skifret Plade, indeholder: Rhynchonella bidentata?, Chonetes striatella, Pterinea sp. Beyrichia Buchiana, B. nodulosa, Kloedenia Wilckensiana, Cytherellina siliqua og Bythocypris sp. En ca. $3 \mathrm{~cm}$. tyk Plade af svagt krystallinsk Kalksten af graa Farve med en Tone i rødligt, minder i høj Grad om Kalkstenslagene i den øvre Del af Lagrækken ved Klinta i Skaane og indeholder: Rhynchonella nucula, Chonetes striatella, Pholidops antiquus, Tentaculites tenuis, Beyrichia Buchiana, B. nodulosa, Kloedenia Wilckensiana, Kl. Kiesowii, Bythocypris sp. Aparchites obsoletus og Cytherellina siliqua. Et mindre Stykke tæt graa Kalksten, der ser ud til at have været en Bolle i Skifer, indeholder: Orthoceras sp., Beyrichia Salteriana, B. Buchiana, B. Steusloffi, B. nodulosa?, Kloedenia Kiesowii, Cytherellina siliqua, Bythocypris sp. og Aparchites obsoletus.

En graa tæt Kalksten, rig paa Ostrakoder, hvis Skaller dog hyppigst sidde saa fast i Stenartsmassen, at de kun ses i Gennemsnit, og hvoraf kun faa kunne bestemmes sikkert, turde ogsaa stamme fra Skaane, men sikkert at afgøre det er umuligt paa Grund af de manglende palæontologiske Beviser. Den indeholder Beyrichia Buchiana, B. nodulosa?, Aparchites obsoletus, og af Brakiopoder Rhynchonella bidentata, Chonetes striatella og Pholidops antiquus.

For tre Blokke af Beyrichiakalk er det umuligt at bestemme Hjemstedet. Den ene er en graalig, noget krystallinsk Kalksten med sparsomme Forsteninger, Pholidops antiquus, Chonetes striatella, Rhynchonella bidentata og Beyrichia M'Coyiana. To andre Blokke bestaa af mere tæt Kalksten, hvor Ostrakodskallerne ligge saa fast indlejrede, at man kun ser dem i Tversnit paa Brudfladerne. Den ene er graalig med et Anstrøg af blaat og indeholder Rhynconella nucula, 
Pholidops antiquus, Beyrichia M'Coyiana og Bythocypris sp.; den anden er lysegraa og indeholder Beyr. Buchiana, Aparchites obsoletus samt en Snegl, formodentlig Holopea sp.

Af øvresilurisk Kalksten findes yderligere 7 Blokke, som ikke med Sikkerhed kumne henføres til noget bestemt Hjemsted og heller ikke til nogen bestemt Stenartsgruppe. En Blok af Konglomerat med Boller af tæet graa Mergelkalksten i en graa, noget krystallinsk Grundmasse, hvorimellem ses rødlige eller gullige Kalkspatpartier, indeholder daarligt bevarede Brakiopoder, hvorimellem Pholidops antiquus og Chonetes striatella, enkelte Ostrakoder, f. Eks. Aparchites obsoletus, Fragmenter af Calymmene, samt nogle Bryozoer, hvorimellem mærkes Ptilodictya. Blokkens Hjemsted er ubestemt, selv om noget taler for Gotland. To andre Blokke indeholde forholdsvis mange Brakiopoder, og i Stenarten ses ogsaa Ostrakodskaller i Tværsnit. Den ene er helt tæet, af lysegraa Farve med enkelte gullige Partier og har af Forsteninger Orthis sp. (O. crassa?), Pholidops antiquus og Tentaculites ornatus. Den anden er en tæt graa Kalksten, hvori der i Tværsnit ses Skaller af Forsteninger og krystallinsk Kalkspat, og har af bestemmelige Forsteninger kun Pholidops antiquus og Chonetes striatella. Tre Blokke af temmelig tæt Kalksten af graa Farve i lidt forskellig Nuance indeholde Muslinger i temmelig stor Mængde, men saa daarligt bevarede, at de end ikke kunne bestemmes til Slægt. Af andre Forsteninger indeholder den ene Cornulites serpularius. For disse 5 Blokke er det ikke muligt at udtale noget angaaende deres Hjemsted. Heller ikke for en Blok af lysegraa Kalksten, for største Delen tæt med enkelte hvide Kalkspatpartier fra Krinoidéer. I Kalkstensmassen findes ogsaa Stromatoporer og en enkelt rugos Koral. Hjemsted ubestemt, selv om noget taler for Gotland.

c) Øvresilurisk Sandsten. Fra Skaane stammer derimod med fuld Sikkerhed en Blok af graa, kalkholdig og glimmerrig, skifret Sandsten, som indeholder en Del Muslinger, hvis Skaller ere opløste og erstattede med et Overtræk af Jerntveiltehydrat. Et Par Ekspl. synes at kunne henføres til Sl. Modiolopsis. Blokken hidrører fra de Sandstenslag, som danne den øverste Del af Skaanes Øvresilur, og ligner mest Stenarter, som findes i Ringsjøegnen ved Klinta.

\section{Ræt-Lias og Jura.}

\section{Ræt-Lias.}

To Blokke af Jernlersten, den ene ganske tæt, uden Spor af Forsteninger, den anden indeholdende Kvartskorn og Partier af kulsur Kalk, der tildels synes at være Fragmenter af Fossilskaller, tildels 
senere Infiltration, samt et enkelt Belemnitfragment - tilhøre rimeligvis Ræt-Lias, men angaaende deres Hjemsted er det umuligt at udtale nogen Mening.

\section{Cyrenabjergarter.}

Af Cyrenablokke er der fundet to af meget forskellig Beskaffenhed. En lysegraa Kalksandsten, der ved Forvitring bliver noget gullig, indeholder en stor Mængde Cyrenaer af en lille Art. En mørkegraa spraglet Muslingebreccie indeholder foruden Cyrenaskaller enkelte Fragmenter af andre Skaller og stemmer ganske overens med Cyrenablokke, der ere fundne betydelig nordligere f. Eks. i Grenaaegnen. Angaaende disse Blokkes Hjemsted skal her fremhæves, at selv om Sandsynligheden er størst for, at de stamme fra Østersøen, saa er der dog en Mulighed for, at deres Hjemsted ligger i Kattegat. (D. G. U. II. R. Nr. 15, S. 22).

\section{Kelloway.}

Der er funden en stor Blok af en gullig- eller brunliggraa uren Kalksten med en Mængde Forsteninger, af samme Slags, som plejer at forekomme i Kellowayblokke. Dens Hjemsted er at søge i den østlige Del af Østersøbassinet.

\section{Andre Blokke.}

To Blokke, som ikke have kunnet henføres til nogen tidligere kendt Stenart, og hvis Fauna har et bestemt jurassisk Præg, omtales her. Den ene er en temmelig tæt Kalksandsten med Muslingeskaller, af lys blaagraa Farve, ved Forvitring gulliggraa i de ydre Partier. Af Forsteninger iagttoges Perna? sp. Lima sp., Astarte sp. og Brakiopoder. Blokkens Habitus og Forsteninger synes at tyde paa Sammenhæng med den pommerske øvre Jura. Den anden er en temmelig grov, mørkegraa Kalksandsten, hvor Kvartskornene kun ere sammenkittede af kulsur Kalk, og som petrografisk minder om visse Cyrenablokke; den indeholder en Mængde Forsteninger, der vanskeligt lade sig præparere ud, mest tykskallede Muslinger og daarligt bevarede Snegle. Muslingerne tilhøre mest Slægterne Astarte, Trigonia, Ostrea og Pecten. I Mineralogisk Museums Bloksamling findes en lignende Blok fra Palsgaard. At denne Blok hidrører fra Juradannelser, turde være sikkert nok, men med Hensyn til Hjemsted og nærmere Alder staa vi ganske usikre.

Disse to nævnte Blokke vise ingen petrografisk Lighed med de $i$ det nordlige Jydland fundne Blokke af Jura og ældre Kridt (beskrevne af Dr. Madsen og Miss Skeat i D. G. U. II. R., Nr. 8), og Dr. 
Madsen har erklæret, at han ikke anser det for rimeligt, at de høre sammen med de omtalte Blokke. Stor Sandsynlighed for, at de ere førte herhen nordfra, synes der saaledes ikke at være til Stede. Rimeligere er, at de begge stamme fra Østersøen.

\section{Kridt.}

\section{Senon.}

Af Kridt-Grønsandsten er der fundet to Blokke, hvoraf den ene stemmer saa godt overens med Køpingesandstenen, at den maa henføres dertil, den anden kan ikke nærmere bestemmes, men maa være baltisk.

\section{Danien.}

Af de talrigt forekommende Blokke af Saltholmskalk er der hjembragt en, som meget nær stemmer overens med RøRDAM's Foraminiferkalk (f. Eks. fra Østre Gasværk i Kjøbenhavn). Denne Blok bestaar af en tæt gullig Kalksten, der synes at have undergaaet en grundig Omkrystallisation og af Forsteninger kun indeholder et Serpularør. Af Faxekalk med Koraller foreligger der 3 Blokke.

\section{Tertiær.}

\section{Paleoeæn.}

Af Stenarter, der maa anses for at høre sammen med Danmarks paleocæne Dannelser (Aflejringerne fra Kjøbenhavns Vestre Gasværk, Lellinge og Kerteminde) er der hjembragt 8 Blokke, alle af glaukonitiske Mergelstenarter, de fleste temmelig stærkt forkislede. En af de lettere Mergelblokke indeholder Aporrhais gracilis v. K. og Cristellaria. Stenarten er graa, noget mørkflammet samt forholdsvis rig paa Glimmer, og minder om enkelte askegraa Paleocænblokke fra Kjøbenhavn. De stærkt forkislede Blokke have dels grønlig og dels graaligblaa Farve og meget tydelig Lagdeling, der bedst ses paa en forvitret Overflade.

En enkelt af dem er temmelig flammet, og en indeholder af Forsteninger Indtryk af en stærkt spiralornamenteret Turrittella. Ellers mangle Forsteninger ganske.

\section{Blokke fra yngre Tertiær og af ubestemt tertiær Alder.}

Af de almindeligt forekommende Jernlersten, som rimeligvis stamme fra det plastiske Ler og have været indesluttede $\mathrm{i}$ dette som Konkretioner, foreligger der 5 Stykker, alle uden Spor af For- 
steninger. Af sandet Jernlersten er der hjembragt 4 Blokke, af hvilke 2 indeholde Forsteninger; en teglrød Stenart har helt hvide kalcinerede Molluskskaller, og en graalig brun, noget krystallinsk Stenart indeholder Muslingskaller bevarede som Jerntveiltehydrat, der dog hyppigt er helt opløst, saa at man ser Forsteningerne som Aftryk. Af jernholdig Sandsten findes to Blokke, hvoraf den ene indeholder et Aftryk af en Snegl og den anden meget ubetydelige Fragmenter af Skaller. Af Blokke med velbevarede Forsteninger findes to Stykker, en af en jernholdig Sandsten med talrige Skaller, især af Muslinger, nogle dog ogsaa af Snegle samt hyppigt Rør af en Serpula eller Ditrupa; det andet Stykke er en Kalksandsten, hvor Skallerne hyppigst ere sønderbrudte.

Af den traadede Kalkspat, tidligere kaldet Aragonit, som findes i de danske Tertiærdannelser, foreligger der ogsaa en Blok.

Docent J. P. J. Ravn har venligst gennemset de yngre Tertiærblokke og erklærede, at han ikke mellem dem kunde finde nogen Stenart, som med Sikkerhed kunde henføres til de kendte Forekomster af Tertiærdannelser i nordligere Dele af Jydland."

Foruden Blokkene fra Vargaarde Strand er der kun indsamlet faa sedimentære Blokke indenfor Kortbladsomraadet, og om disse Blokke udtaler Dr. Grönwall:

„En lysegraa Kalksandsten, som i enkelte Partier er noget mergelholdig, indeholder tre Eksemplarer af Inoceramus lobatus MüNSTER, og nogle ubestemmelige Østersskaller. Stenarten synes ifølge Beskrivelsen i „Lethæa erratica"1) at stemme ganske overens med Blokke af lignende Art fra Øst- og Vestpreussen, men hvori der dog findes en rigere Fauna. Man antager, at disse Blokke stamme fra den Del af Østersøen, som ligger Nord for Øst-og Vestpreussen. Blokken er fundet ved Gejlhave Gaard, N. for Vonsild. Dens Alder er nedre Senon.

Fra Egnen V. for Kobbelhaveskoven i Vonsild Sogn foreligger der en Blok af lysegraa, tæt, opallignende Flint, der af Forsteninger indeholder talrige Eksemplarer af en lille glat Pecten med vel ornamenterede Ører, men saa daarligt bevaret, at den ikke kan bestemmes, samt en Scalaria. Flinten stemmer ikke overens med nogen af de Flintarter, som man kender fra faststaaende Lag. Dens petrografiske Karakter tyder nærmest paa Danien.

1) Roemer. Lethæa erratica. Palæontolog. Abhandl. herausgegeben von Dames und Kayser. 2. Bd. 5. Hefte S. 155 (402). Berlin 1885.

Schroeder. Zeitschr. d. d. geol. Ges. Bd. 30. S. 686. 1878. 
Tæt Syd for Stendrup Gaard er der paa Marken fundet en Blok af Faxekalk med Koraller.

I en Mergelgrav i den nuværende Have ved Fredrikshøj Kro er der fundet forkislet Træ, ualmindelig vel bevaret. I et Stykke fandtes Borerør fra en Boremusling. Træet er rimeligvis tertiært.

En Blok af en brunlig Stenart, sammenkittet af runde Korn, rimeligvis af Glaukonit eller et Forvitringsprodukt af denne, indeholder enkelte Molluskskaller helt hvide og kalcinerede. Stenarten minder meget om Forekomsten red Hindsgavl. Blokken er funden "in situ“ i Moræneleret i Skrænten Syd for Stendrup Hage.

Fra forskellige Steder - mest fra Grusgrave - foreligger der Blokke af en Mergelbjergart mer eller mindre forkislet, der kun indeholder faa og meget daarligt bevarede Forsteninger, hovedsagelig Foraminiferer. Denne Stenart minder i nogle Typer stærkt om mere forkislede Varieteter af Kertemindeleret; den hører uden Tvivl til Paleocænet, og dens Hjemsted maa findes i Nærheden af Lillebelt. Stenarten kaldes paa Egnen „Griffelsten " (Sml. Side 8)."

"Med Hensyn til disse Blokkes Oprindelse og de Transportveje, ad hvilke de ere komne til deres nuværende Leje, kan man som en almindelig Slutning sige, at den overvejende Hovedmasse tyder paa en Transport fra Østersøbassinet, medens enkelte kunne have en nordlig Oprindelse, selv om det for de fleste af disse sidstes Vedkommende er mere sandsynligt, at de ere lokale Blokke, der kun have været underkastede en meget kort Transport.

Silurblokkene er alle at regne for baltiske og særlig maa fremhæves, at der ogsaa forekommer Blokke, hvis Oprindelse maa søges saa østlig som Øsel og de russiske Østersøprovinser, f. Eks. Beyrichiakalk med B. tuberculata.

Mellem de mesosoiske Blokke er der en vis Rimelighed for, at den ene Cyrenablok maa regnes som en nordlig Blok. RætLiasblokkene ere fuldstændig ubestemte. De to Jurablokke af ubekendt Art turde stamme fra Østersøen. Kellowayblokkene have sikkert en meget østlig Oprindelse, endog muligvis fra de russiske Østersøprovinser. Kalksandstenen med Inoceramus maa ogsaa regnes som en meget østlig Blok med Østersøen Nord for Preussen som Hjemsted. Øvrige Kridtblokke turde regnes som Østersøblokke eller delvis som lokale.

De tertiære Blokke maa vel nærmest anses som lokale; i ethvert Tilfælde kunne de næppe afgive noget sikkert Vidnesbyrd om Isens Bevægelsesretning; det har jo heller ikke været muligt at henføre nogen af dem til bestemte Hjemsteder, undtagen maaske en paleocæn Blok, som havde Lighed med Blokke fra Kjøbenhavn, men 
som dog kan have sit Hjemsted betydelig længere mod Vest, og en anden, som ligner Stenarten ved Hindsgavl.

Hovedmassen af Blokkene tyder bestemt paa en baltisk Transport og særligt maa her fremhæves, at enkelte tyde paa en Transport fra netop de sydligere og østligere Dele af Østersøbassinet, og at nordlige Blokke ere sjældne; navnlig er det næppe muligt sikkert at konstatere en nordlig Transport for de Blokkes Vedkommende, der nærmest maa betragtes som lokale.

I det store og hele kunne de sedimentære Blokkes Transportretninger siges at stemme godt med de krystallinske Blokkes; mellem det overvejende Flertal af baltiske Blokk eer der fundet enkelte norske."

Endnu maa nævnes de diluviale Dyrerester, der ere fundne paa sekundært Leje indenfor Kortbladsomraadet.

Da nogle Stenfiskere i 1899 tog Sten i Stranden ud for det nordligste af Teglværkerne mellem Hejlsminde og Vargaarde (N 2), fandt

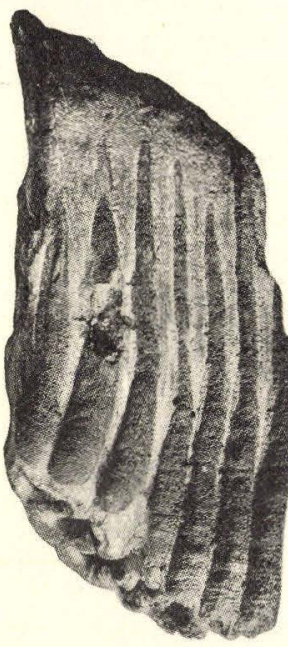

Mammuth-Kindtand, Brudstykke, fra Stranden N. for Hejlsminde. For neden ses den aabne Rodende med Tandpladernes Underkanter. de en Kindtand af Mammuth (Elephas primigenius) liggende paa omtrent 1 Meter Vand. Tanden, der ikke er slidt og ikke har været i Brug, er flækket langs en Dentinplade. Da der ikke paa dette Sted af Kysten foregaar nogen Materialvandring af Betydning, maa man antage, at Tanden sammen med de større og mindre Sten, der dække Havbunden, er bleven udvasket af Kystens glaciale Aflejringer.

Paa en Del Steder i den østlige Del af Kortbladsomraadet (Øst for en Linie fra Stendrup gennem Skamlingsbanke til Hejls) er der saavel i Moræneler og Morænegrus som i lagdelt Diluvialgrus fundet Fragmenter af diluviale Molluskskaller. En stor Del af disse Fragmenter har kunnet bestemmes og er anført i hosstaaende Tabel. Hvor der af en Art kun fandtes enkelte Fragmenter, er disses Antal angivet; et $X$ betyder at Arten var rigeligt repræsenteret. Den hyppigste og paa alle Lokaliteter forekommende Art er Cyprina islandica, et Forhold, der næppe alene har sin Forklaring i denne Muslings solide Skaller; i adskillige Tilfælde er der nemlig ogsaa fundet let bestemmelige Fragmenter af meget tynde og skøre Skaller. Blandt de øvrige Former bør nævnes Fragmenterne af en Tapes, der paa Grund af Størrelsen og Skallens Skulptur maa 

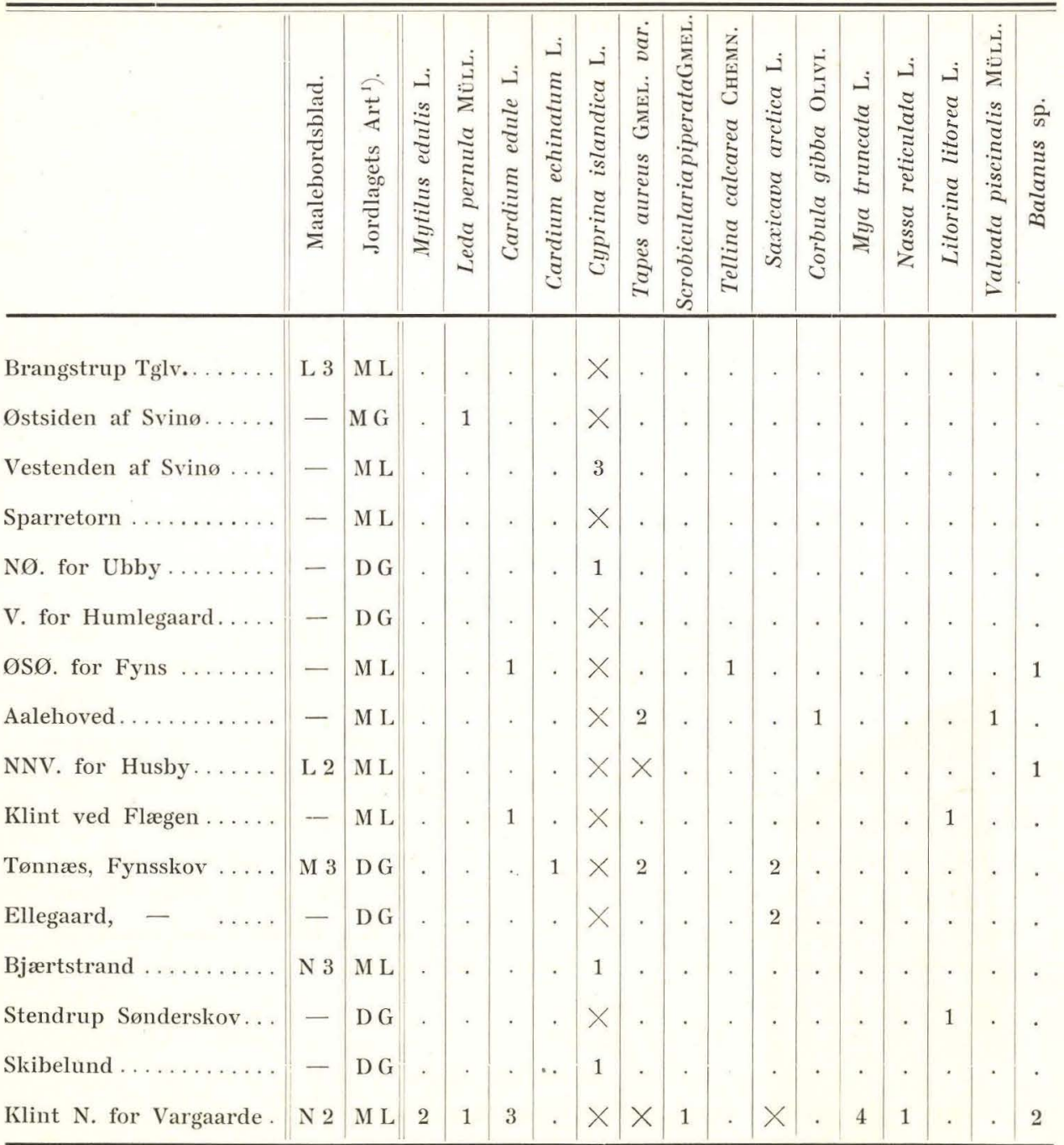

henføres til den store Varietet af Tapes aureus; som forekommer ved Tønder ${ }^{2}$ ) og i Tapessandet ved Stensigmose paa Broager ${ }^{3}$ ).

I flere Henseender minder Faunaen fra Diluviet paa Kortbladet Skamlingsbanke saaledes om Cyprinalerets Fauna, dog kendes hverken Leda pernula eller Tellina calcarea fra Cyprinaleret, og desuden have de fundne Skalfragmenter af Saxicava arctica et ganske andet

1) $\mathrm{ML}=$ Moræneler, $\mathrm{M} \mathrm{G}=$ Morænegrus, $\mathrm{D} \mathrm{G}=$ Diluvialgrus.

$\left.{ }^{2}\right)$ P. Harder: En ny sønderjysk lokalitet for marint diluvium. Medd. Dansk geol. Foren. Nr. 6. Kjøbenhavn 1900. Tavle 2.

3) C. Goтtsche: Über den Tapes-Sand von Steensigmoos. Monatsbericht der Deutschen geol. Gesellsch. Nr. 10. 1904. 
borealt Præg end Cyprinalerets Former. For de boreale Formers Vedkommende er Hjemstedet maaske snarere at søge i et Lag, der svarer til det tæe Nord herfor - i Røgle Klint ved Strib - forekommende "Tellinaler"1). Der er saaledes Rimelighed for, at de omkring det nordlige Lillebelt fundne, diluviale Skalfragmenter hidrøre fra forskellige marine og af Landisen delvis ødelagte Aflejringer.

\section{B. Lagdelte Diluvialaflejringer.}

De indenfor Kortbladsomraadet fundne lagdelte Diluvialdannelser indeholde ikke Dyre- eller Planterester paa primært Leje; de maa antages at være aflejrede i Ferskvand og i nøjeste Forbindelse med Indlandsisen. Kun paa et enkelt Sted, ved Wedellsborg (L 2), synes man ved en Boring (Boring XII i Tillæget) at have truffet et fossilførende Lag. I en Dybde af 25,5 m. under Overfladen kom man nemlig igennem et $16,9 \mathrm{~m}$. mægtigt Lag "Blaaler", der angives at være fedt, sejgt og ildelugtende. I den øverste Del indeholdt det „en Mængde smaa, halvforraadnede Muslinge- og Snegleskaller". Desværre er der ikke opbevaret Prøver fra den over 20 Aar gamle Boring; noget sikkert kan man derfor ikke sige om dette Lag, men uvilkaarligt ledes Tanken hen paa det ved Kysterne omkring det sydlige Lillebelt saa almindelige Cyprinaler. Laget har, saafremt det er Cyprinaler, en tilsyneladende meget stor Mrgtighed; imidlertid nævnes der i Borejournalen kun Skaller fra Lagets øverste Del. Desuden er det ikke urimeligt, at man her staar over for enten en løs, af Landisen transporteret og sammenæltet Flage, eller meget stejltstaaende Lag.

\section{Lagdelt Diluvialler.}

Diluvialleret har som Overfladedannelse en meget ringe Udbredelse; kun paa Vestsiden af Lillebelt, tæt Nord for Hejlsminde, optræder det med regelmæssige Lejringsforhold over en større Strækning. Oftest findes det som underordnede Lag i Diluvialsandet, lokalt desuden som Lag i Moræneler.

Paa den fynske Del af Kortbladsomraadet findes gode Profiler i Diluvialler i Brangstrup Teglvarks Lergrav, der ligger omtrent $1 \mathrm{~km}$. Vest for Brangstrup By (L 3). I de 4-5 m. høje Lervægge ses øverst $1 \frac{1}{2}-2 \frac{1}{2} \mathrm{~m}$. Moræneler, - der pletvis har optaget saa meget Sand og Grus i sig, at det paa disse Steder kan kaldes Morænesand, - og derunder Diluvialler, hvis nedre Grænse og Underlag

1) V. Madsen: Istidens Foraminiferer. Medd. Dansk geol. Foren. Nr. 2. Kjøbenhavn 1895. S. 104 . 
er ukendt. De øverste Par Meter af Diluvialleret ere rødgule, den nederste Del er mørkegraa og uforvitret. Man ser, hvorledes Leret har været udsat for et stærkt Tryk, hvorved det er blevet knust til nøddestore, skarpkantede Brokker, men andre Forstyrrelser kunne ikke paavises. I det store og hele synes Lermassen at være urørt, idet parallele Sandlag af $2 \mathrm{~cm}$. Tykkelse strække sig omtrent horizontalt gennem hele Profilet.

Det ejendommelige lagdelte, stenede Diluvialler, der findes som Bænke i Moræneleret i Klinterne ud mod Lillebelt, saaledes i Klinten Sydvest for Wedellsborg og paa Sydsiden af Fynsskov, baade Øst og Vest for Tønnæs Enghave, er omtalt Side 24. Som allerede nærnt staar denne Aflejring som en Overgangsform mellem Diluvialler og Moræneler. Leret er stenet og kan paa flere Steder gaa aldeles jæunt over i almindeligt Moræneler, men som oftest skilles det let derfra ved at indeholde kun meget fine og meget grove Bestanddele, saaledes at man ikke har den for Moræneleret typiske Blanding af alle mulige Kornstørrelser. Undertiden indeholder det en Mængde Kalkkonkretioner af Størrelse som et Knappenaalshoved; det er tydelig lagdelt i $5-10 \mathrm{~cm}$. tykke Lag og er utvivlsomt aflejret i Vand. Men medens man maa antage, at største Delen af det typiske, lagdelte Diluvialler er aflejret i Søer udenfor Isranden, maa det her beskrevne, stenede Diluvialler anses for en subglacial Dannelse, hørende til Bundmorænen og aflejret af lerfyldt, næsten stillestaaende Vand inde under Indlandsisen. De i Leret indesluttede Sten ere sandsynligvis faldne ned fra Undersiden af den dækkende Is.

I Egnen omkring Tybrind, Husby og Wedellsborg (L 2) maa stenfrit Diluvialler være temmelig almindeligt blandt de dybere liggende Lag, hvad der fremgaar af Boringerne VII, VIII, X og XI.

Vest for Lillebelt er Diluvialleret bedst udviklet tæt Nord for Hejlsminde (N 2). Paa en Strækning af omtrent $2 \mathrm{~km}$. Længde og den halve Bredde mangler det dækkende Moræneler, eller det forekommer kun paa meget smaa Arealer, saaledes at de under Morænen liggende lagdelte Diluvialdannelser næsten overalt gaa i Dagen. Fra Kysten strækker der sig flere Lavninger ind i Landet; de ere aabenbart fremkomne ved en stærk Erosion, der dog ikke skyldes Vandløb men Indlandisen, da denne fra Øst bevægede sig op over Højlandet. Egnen Nord for Hejlsminde kan betragtes som en "Stødside“, hvor ikke alene Bundmoræenen mangler, men hvor der desuden er gravet store Partier bort af de underliggende Dannelser. Lagfølgen i disse er øverst Diluvialsand, pletvis med lidt Diluvialgrus, og derunder Diluvialler, der kommer frem i Bunden af Dalene og i Foden af Skrænterne ud mod Lillebelt. Under Diluvialleret findes atter Diluvialsand. 
I den $15 \mathrm{~m}$. høje, for største Delen bevoksede Skrænt mellem Slusen og Hejlsminde Teglværk ser man endnu Moræneleret som det øverste Lag; derunder træffes Diluvialler og Diluvialsand. I den sydlige Lergrav, ved Hejlsminde Teglværk, er man nede i det lavere Terrain, hvor de øverste Lag ere eroderede bort. Moræneleret ses kun i Lergravens Sydende og har dér en Mægtighed af $1 \mathrm{~m}$. I den øvrige Del af Profilet er det øverste Lag hvidgult Sand med utydelig Lagdeling og Striber af graabrunt, stenfrit Ler; dets Mægtighed er c. 2 m. Derunder findes $3-4 \mathrm{~m}$. stenfrit Diluvialler (Teglværksleret) med tynde Sandlag. Allerede paa Afstand ses tydeligt den regelmæssige, horizontale Lagdeling, men Leret selv er i Virkeligheden fuldstændig brokket. Det er iøvrigt meget uensartet og veksler fra lyst og sandet til graabrunt, yderst fedt Ler, der kan spaltes ud i ganske tynde Blade; eller man finder inde i det lyse, magre Ler skarpkantede, nøddestore Brokker af meget fedt, mørkegraat Ler. I Lergravens nordligste Parti ses under Diluvialleret horizontalt lagdelt, gult Diluvialsand, hvori der angives at være boret over et halvt Hundrede Meter, uden at man er naaet gennem det.

I det tæt Nord herfor liggende Teglværks Lergrav er Profilet omtrent det samme: $2 \mathrm{~m}$. gult, leret Diluvialsand, derunder $2 \mathrm{~m}$. graat, sandet Ler med utydelig, horizontal Lagdeling, derunder $2-3 \mathrm{~m}$. meget fedt, graat Diluvialler, der paa sine Steder er uforstyrret lagdelt, paa andre Steder fuldstændig brokket. Det underlejres af $2 \mathrm{~m}$. gult Diluvialsand, hvorunder der - i Havets Niveau - findes vandførende Grus.

I det tredie Teglværks Lergrav findes en lignende Lagserie, dog er her bevaret et lille Parti Moræneler som Dække over de lagdelte Dannelser. Det var her ud for, at den Side 44 omtalte Kindtand af en Mammuth fandtes.

Diluvialleret og det derover liggende Diluvialsand kan fra dette Sted følges Nord paa i den bevoksede Strandklint over en lang Strækning. Pletvis kan der over disse Aflejringer paavises et tyndt, i Reglen udvasket Lag af gulbrunt "Moræneler. Nord derfor, ved Kalvehøj, bliver Skrænten højere og bestaar fra øverst til nederst af Moræneler (se Fig. 5, Side 21).

Vest paa kan Diluvialleret følges henved $1 \mathrm{~km}$. ind gennem Dalene, og efter Lejringsforholdene at dømme er det utvivlsomt det samme Lag, som er truffet ved Boringen $400 \mathrm{~m}$. Øst for Hejls Kirke (Boring XVII i Tillæget). Ganske vist ligger Lerlaget her c. $18 \mathrm{~m}$. under Havets Niveau, men da Afstanden ud til Østkysten er 2 km., er Faldet meget ringe. Kun paa faa Steder finder man et enkelt Lag af Diluvialler, der indtager et saa stort Areal og ligger saa uforstyrret, til Trods for at en Indlandsis er passeret hen derover. 
I det Nord og Vest herfor liggende Terrain er Diluvialleret sjældent; hvor det findes - i Dalskraaningerne red Grundinghoved og Nordøst for Bjært (O 3), Nord og Sydvest for Vonsild (P 3) og flere Steder - har det kun ringe Udstrækning, og af Mangel paa gode Profiler er dets Lejringsforhold ikke tilstrækkelig oplyste. Ofte er det helt eller delvis dækket af et tyndt Lag Moræneler, paa andre Steder synes det at følges med Diluvialsandet og som flade Banker at rage udækket frem i Overfladen; eller det er - i Dalskraaningerne - bleven blottet ved Vandets og Landisens Erosion, da Dalene dannedes.

Diluvialleret er meget varierende med Hensyn til dets mekaniske Sammensætning, ikke alene paa de forskellige Lokaliteter, men som Regel ogsaa i samme Lervæg. Det kan veksle fra meget ensartet, fint og fedt Ler, der ikke synes at give det plastiske Ler noget efter med Hensyn til Finhed, til meget sandblandet, magert Ler, der staar paa Overgangen til leret Sand. I Tillag II er opført mekaniske Analyser af Diluvialler fra forskellige Lokaliteter.

Kalkholdigheden er i de uforvitrede Lag som oftest stor, i Reglen langt større end i Moræneleret. Som Eksempler kan nævnes: Diluvialler, Brangstrup Teglvæerk, $39 \%$ kulsur Kalk.

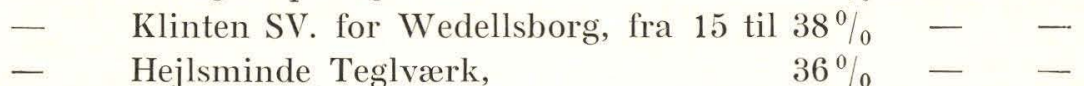

Hvor Diluvialleret optræder med tilstrækkelig stor Mægtighed og: Udstrækning, har det stor Værdi som Teglværksler, men dette er, som allerede nævnt, kun Tilfældet paa et Par Steder. Ogsaa de smaa Forekomster have været udnyttede, men de fleste af disse mindre og primitive Teglværker ere nu nedlagte.

Som Mergel er dets Betydning ringe i denne Egn, hvor kalkholdigt Moræneler er saa almindeligt og saa let tilgængeligt.

\section{Lagdelt Diluvialsand.}

Som tidligere nævnt hviler Moræneleret i denne Egn næsten overalt paa Diluvialsand, der altsaa har en overordentlig stor Udbredelse og samtidig stor Betydning for Grundvandets Bevægelse og Landets Dræning. Men ogsaa som Overfladelag er Diluvialsandet ret almindeligt, idet man kan se bort fra den tynde Kappe af stenet Sand, hvoraf det paa de fleste Steder dækkes.

Øst for Lillebelt optræder Diluvialsandet i større, samlede Partier paa flere Steder. Paa Plateauet Nord for Nørre Aaby Station gaar det i Dagen uden at være dækket af nogen Moræneaflejring. Syd og

Danmarks geologiske Undersøgelse. I. R. Nr. 12. 
Sydvest herfor optræder det almindeligt langs Vibymølle Aa og gaar mellem Byerne Viby og Rodlund udækket til Overfladen; det staar øjensynlig i Forbindelse med det tidligere omtalte Diluvialler i Brangstrup Teglværk. Følges dette Strøg videre Vest paa, finder man ogsaa paa Svinø meget Diluvialsand, der ses i flere Profiler; her er det dog overlejret af stenet Sand, der er meget rigt paa Sten. Nord for Svinø, omkring Gamborg, kommer Diluvialsandet frem i Siderne af Dalene, medens Plateauet ovenfor er dækket af Moræneler.

Et andet, endnu større Areal med Diluvialsand strækker sig fra Tybrind mod Nordvest udad mod Sparretorn paa Fynsskov. (L 3, 2), Medens det nordlige Sandparti ikke synes at have nogen væsentlig Indflydelse paa Terrainformerne, er det modsatte Tilfældet her. Den stærkt markerede Højderyg, der fra Tybrind Skov strækker sig mod Nordvest til Fyns, og i hvilken Terrainet Øst for Lillebelt naaer sin største Højde, bestaar netop af Diluvialsand. Syd og Sydvest for Højderyggen indtager Diluvialsandet store Arealer paa det lavere Land og naaer mod Sydvest ud til Tybrind Vig, mod Syd til Hygen Bæk.

Paa Bogø (M 1) indtager Diluvialsandet den sydlige Del af Øen, og paa den Sydøst derfor liggende Thorø (L II) bestaar næsten hele Højlandet af Diluvialsand.

Vest for Lillebelt kommer Diluvialsandet ret almindeligt frem Vest for Stendrup i Skrænterne langs Solkjær Aa (N, O 3). Noget sydligere findes et stort Sandparti omkring Skamlingsbanke. Hovedmassen af dette Højdedrag bestaar af Diluvialsand, dækket af en Kappe af stenet Sand eller - i Særdeleshed paa Bakkeryggens Kam og paa dens østlige Skraaning - af Moræneler. Diluvialsandet kan herfra følges mod Vest og Sydvest over store Strækninger, og endnu vestligere, omkring Aastorp, kommer det frem paa en Mængde mindre Arealer.

Et andet stort Sandparti findes ved Kysten Nord for Hejlsminde, hvor Diluvialsandet som nævnt (Side 47) optræder i Forbindelse med Diluvialleret.

I Kortbladets vestlige Del kommer Diluvialsandet frem som to store Partier ved Kolding-Haderslev Landevej. I det nordlige Parti, ved Vonsild, er Overfladen jævn og viser ingen Forskel fra Omgivelserne. Sandet naaer mod Vest ud til Sest Aa, hvor det kommer frem i Skrænterne, hyppigt dækket af Moræneler. Diluvialsandet i det sydlige Parti, omkring Johanover og Kokholm, optræder med en smaakuperet og urolig Overflade, hvor Lavningerne ofte ere udfyldte med Ferskvands-Alluvium. Den samme Landskabsform genfindes iøvrigt i Moræneler-Terrainet Vest herfor mellem Landevejen og Svanmose, men er ikke skarpt afgrænset mod Omgivelserne. 
Langs Kortets Vestrand kommer Diluvialsandet frem paa flere Steder, og mod Syd - omkring de store Moser ved Tapsore og Brendore og Vest paa til Kortgrænsen - spiller det en betydelig Rolle.

Diluvialsandets Lejringsforhold ere i det store og hele temmelig ensartede, saa vidt de kunne bedømmes af de foreliggende Profiler. Det maa dog straks bemærkes, at man kun kender meget lidt til Diluvialsandets Underlag. Ved den dybe Boring ved Wedellsborg (Boring XII i Tillæget) synes man at være kommet gennem flere Lag fluvioglacialt Sand („Flydesand“). Rimeligvis er ogsaa det "Flydesand" og „Sten og Grus", der findes under det fede, skalførende Blaaler, og som hviler direkte paa de tertiære Lag, en fluvioglacial Aflejring.

Ved Frederikshøj Kro (Boring XX) findes der under den øverste Moræne 15,6 m. Diluvialgrus, derunder et lige saa mægtigt Lag "Mergel", vistnok Moræneler, og derunder atter Diluvialsand og -Grus, der hviler direkte paa „Brunkul-Ler“. Lige saa vel som der efter al Rimelighed findes flere Bænke af Moræneler, maa man ogsaa i dette Terrain (hvad ogsaa Boringerne vise) kunne finde forskellige Horizonter af Diluvialsand af meget forskellig Alder, svarende til Landisens gentagne Fremrykning og Afsmeltning.

I de Profiler, hvor Diluvialsandets Lejringsforhold ere synlige, er Sandet som oftest dækket af Moræneler eller stenet Sand. Gaar man fra det af Moræneler dækkede Land ind paa Sand-Terrainet, i Særdeleshed hvor det drejer sig om en Sandbanke, der hæver sig op over det omgivende Ler-Terrain, vil man i Reglen ved Boring kunne paavise, hvorledes Moræneleret aftager i Mægtighed, kiler ud og tilsidst forsvinder. Diluvialsandet kan da gaa udækket til Overfladen, eller det kan dækkes af en tynd Kappe af smaastenet Muld, maaske en Udvaskningsrest af Moræneler, eller det kan være overlejret af et noget magtigere Lag "stenet Sand" med spredtliggende, større Sten.

Profiler i Diluvialsandet ses paa talrige Steder. I den nordøstlige Del af Kortbladsomraadet ere Lejringsforholdene overalt uforstyrrede, selv hvor Sandet dækkes af et mægtigt Lag Moræneler. I den høje Sandryg mellem Fyns og Tybrind Skov findes adskillige Profiler; ogsaa her ere Lejringsforholdene uforstyrrede; diskordant Parallelstruktur ses overalt, og den ringe Hældning, som Sandlagene enkelte Steder vise, kan ikke skyldes Forstyrrelser i Overfladen; heller ikke synes den at staa i noget bestemt Forhold til Overfladens Form. Paa flere Steder kan der mellem Sandlagene findes tynde Lag af fint Grus, men de ere saa ubetydelige, at man næsten kan se bort fra dem. Oftest dækkes Diluvialsandet her af stenet Sand af meget vekslende Mægtighed. Hvor Hovedlandevejen skærer Højderyggen, 
ses saaledes et Par oplysende Profiler: i den over 12 m. dybe Sandgrav Vest for Vejen findes nederst fint, hvidt Diluvialsand med uforstyrret Lagdeling og saa godt som uden Gruslag; derover $1 / 2-1 \mathrm{~m}$. almindeligt stenet Sand og øverst indtil $2^{1 / 2} \mathrm{~m}$. „Flyvesand", det vil sige Diluvialsand, der er blæst op paa Marken ovenfor. I Sandgraven Øst for Vejen er Diluvialsandet af meget ensartet Kornstørrelse og fuldstændig frit for Grus og Sten; det dækkes af $0,5-1,3 \mathrm{~m}$. stenet Sand, meget rigt paa Sten. Grænsen mellem de to Lag er bølget og uregelmæssig, og paa flere Steder udfylder det stenede Sand tragtformede Fordybninger i det fine, stenfri Diluvialsand.

Paa Lavlandet Sydvest for Højderyggen dækkes Diluvialsandet af stenet Sand, men spredt rundt om findes desuden en Del Smaapletter af Moræeler over Sandet.

Om Dannelsen af denne ejendommelige Sandryg kan man næppe udtale sig med Bestemthed, før dens høje, til Dels skovbevoksede Fortsættelse mod Sydøst og de tilgrænsende Egne ere undersøgte. Selve Ryggen er ikke dækket af Moræneler; dette naaer paa Nordøstsiden et Stykke op ad Skraaningen, paa Sydvestsiden findes det først nede paa Lavlandet. Derimod er Højderyggens Fortsættelse mod Nordvest, Halvøen Fynsskov, næsten fuldstændig dækket af Moræneler. Da selve den høje Bakkeryg ikke er dækket af nogen Bundmoræne, maa dens Oprindelse rimeligvis være knyttet til Landisens Rand og til det Smeltevand, der her aflejrede det udskyllede Sand. At Sandryggen skulde være dannet parallelt med Isranden, saaledes at Landisens Bevægelsesretning var fra Nordøst til Sydvest, er usandsynligt. Langt snarere angives Isens Bevægelsesretning ved Retningen af Sandryggen og dens Fortsættelse mod Nordvest; Sandryggen maa da være opstaaet ved én, under Isens Bortsmeltning stadig tilbagerykkende Munding af en stor Smeltevandsflod. Som yderligere Støtte for den Antagelse, at Isens Bevægelsesretning faldt sammen med Højderyggens Længdeudstrækning, kan nævnes, at der tæt Syd for Kohave Gaarde, umiddelbart Øst for Kortbladgræensen, findes Rester af en lille Bullestensaas liggende oppe paa Sandryggen. Aasen, der nu næsten er bortgravet, løber omtrent parallelt med Middelfart-Assens Landevej i Retningen NV.-SØ.

Diluvialsandets Lejringsforhold paa Bogø ere tidligere beskrevne (Side 28). Profilet i Klinten Syd for Vestermose viser, at Sandet hviler paa Moræneler; mod Nordøst kan Diluvialsandet desuden følges ind under det Moræneler, der dækker den nordlige Del af Øen.

Paa Thorø dækkes Diluvialsandet dels af stenet Sand dels af Moræneler. I det smukke $3-5 \mathrm{~m}$. høje Profil i Klinten paa Øens Vestside ligger Diluvialsandet temmelig uforstyrret, saavel hvor det dækkes af stenet Sand som af Moræneler. Det sidste tiltager i Mæg- 
tighed hen mod Klintens Sydende (Fig. 3, Side 15) og staar med en meget skarp, paa lange Strækninger horizontal Grænse mod det underliggende Diluvialsand. Længst mod Syd forsvinder Diluvialsandet, og Klinten bestaar udelukkende af Moræneler (Fig. 4, Side 17). Paa et enkelt Sted i Klinten (Fig. 3) findes i Diluvialsandet, $1 / 2-1 \mathrm{~m}$. under dettes Grænse mod Moræneleret, et mørkt, næsten sort, svagt bølget Lag, der har en Tykkelse af $3-6 \mathrm{~cm}$., og som kan følges over en Strækning af mindst $15 \mathrm{~m}$. Farven skyldes forkullede, meget sønderdelte og ubestemmelige Planterester.

Vest for Lillebelt findes gode Profiler i Diluvialsandet i Teglværksgravene ved Kysten Nord for Hejlsminde (N 2). Lejringsforholdene ere beskrevne Side 47. Diluvialsandet, der paa dette Sted sjældent dækkes af Moræneler, findes sammen med det mægtige og udstrakte Lag af Diluvialler og saavel under som over dette. Lagdelingen i det over Diluvialleret liggende Sand, der er svagt leret, og som kan indeholde Striber af stenfrit Ler, er i et Par af Profilerne temmelig utydelig; paa andre Steder er den meget iøjnefaldende, horizontal og uforstyrret. Det under Diluvialleret liggende Sand indeholder ofte Gruslag og er ligeledes uforstyrret lagdelt.

I Højdedraget omkring Skamlingsbanke spiller Diluvialsandet en fremtradende Rolle. De faa og temmelig daarlige Profiler, der findes her, give dog ikke noget sikkert Billede af, hvorledes Bakkeryggen er bygget op. Der er ingen Tvivl om, at Diluvialsandet danner Kærnen og Hovedmassen af Banken, og at Moræneleret, der skyder sig hen over Sandet med meget uregelmæssig Begrænsning, er af ringe, men iøvrigt stærkt vekslende Mægtighed. Af Lejringsforholdene er det lige saa vanskeligt at give et paalideligt Billede. I enkelte Profiler ses en overraskende regelmæssig og uforstyrret Lagdeling til Trods for den kuperede Overflade. I andre Profiler findes bøjede og stejltstillede Lag af Sand og Grus, og blandt andet viser den Maade, hvorpaa Sand og fint Grus af tertiært Præg optræder nemlig som større Indlag, undertiden med næsten lodrette Grænser mod det omgivende Sand, - at forstyrrede Lejringsforhold ikke ere sjældne, omend de næppe synes at have haft nogen større Indflydelse paa Terrainformerne.

Længere Vest paa, hvor Terrainet er jævnere, tyde de faa og som Regel smaa Profiler, som findes dér, paa rolige og temmelig uforstyrrede Lejringsforhold, sely hvor Diluvialsandet dækkes af Moræneler. Dette ses f. Eks. overordentlig smukt i en Sand- og Grusgrav ved Aastorp (O 3). Profilet, der har en Højde af 8 m., viser øverst $1 \frac{1}{2} \mathrm{~m}$. Moræneler, hvis nederste Del er tydelig bænket, og hvis Underflade er fuldstændig horizontal; derunder ses aldeles horizontale Lag, afvekslende af hvidt Diluvialsand og rustfarvet Grus. 
Lejringsforholdene ere saa regelmæssige, at man - saafremt Moræneleret ikke havde vist det modsatte - næppe skulde tro, at en Indlandsis havde hvilet paa disse Lag og bevæget sig hen over dem.

Nær Kortets Nordrand, omkring Byerne Stendrup, Bjært, Dalby og Vonsild ses Diluvialsandet ret ofte i Dalsiderne og er da som Regel uforstyrret lagdelt. Som tidligere omtalt (Side 27) synes Diluvialsandet ved Stendrup og flere andre Steder at hvile paa en ældre Moræne, der kommer frem i Foden af Dalskraaningen.

Saavel ved Dalbymølle Bæk som ved Sest Aa nedenfor Vonsild er der paa en Del Steder gravet ind i Dalsiderne, hvorved Jordlagene ere blottede. Som Regel er Lagserien øverst Moræneler, oftest 2 til $3 \mathrm{~m}$. mægtigt og derunder Diluvialsand med underordnede Gruslag og med horizontal, uforstyrret Lagdeling. I en Sandgrav paa Østsiden af Dalbymølle Bæk, Sydvest for Dalby Kirke, ses i den omtrent $7 \mathrm{~m}$. høje Væg øverst et tyndt Lag Moræneler og derunder fint, lyst Diluvialsand med uforstyrret Lagdeling. I Foden af Profilet findes et $1 / 2 \mathrm{~m}$. mægtigt Lag Sand, der er mørktfarvet af forkullede og fintmalede, ubestemmelige Planterester. Noget højere oppe i Profilet findes endnu et Par Lag af omtrent samme Beskaffenhed. Medens det lyse Diluvialsand overalt i Profilet viser en stærkt udviklet diskordant Parallelstruktur, ere Lagene i det mørktfarvede Sandparti meget fine, horizontale og fuldstændig uden Diskordans. Man faar herved et Indtryk af de meget vekslende Forhold under Aflejringen af de fluvioglaciale Lag; det lyse, diskordant lagdelte Sand er aflejret i rindende Vand, i Smeltevandsfloderne foran Indlandsisen, hvorimod de mørktfarvede, parallelt liggende Sandlag med de lette, forkullede Planterester maa være bundfældede i stillestaaende Vand, rimeligvis i én, i kort Tid eksisterende, mindre Sø.

I Terrainet Syd og Vest for Fovslet Skov (P 3), hvor Morænen veksler i Mægtighed, og hvor Diluvialsandet kommer nær op til Overfladen paa en Del Steder, synes Lejringsforholdene at være mere urolige. I de faa Profiler, der findes, ses ofte bøjede og skraatstillede Sandlag umiddelbart under Moræneleret.

Endnu sydligere, i Nærheden af den slesvigske Grænse, er Diluvialsandet som Regel uforstyrret lagdelt mod Øst omkring Taps og Haderslev-Landevej, hvorimod det Vest paa omkring Tapsore, og i endnu højere Grad i Bakkerne ved Brendore, viser mere eller mindre forstyrrede Lejringsforhold.

I en stor Sand- og Grusgrav Nordvest for Tapsore (P 2), paa Nordsiden af Mosen, ses saaledes i det $8-11 \mathrm{~m}$. høje Profil øverst et tyndt Lag Moræneler, derunder - i Nordvest-Væggen - henved $2 \mathrm{~m}$. Diluvialsand med Gruslag i temmelig vandrette Lag, derunder en 2 m. mægtig Bænk Moræneler, hvis Sten for en Del ere ordnede 
i Rækker, og derunder igen Diluvialsand og Diluvialgrus. Mod Nord kiler den nedre Morænebænk ud og forsvinder, saa at man i NordøstVæggen under det øverste Moræneler kun finder fluvioglacialt Mateteriale, der her staar med foldede, skraatstillede, ja endog lodrette Lag.

I en Sand- og Grusgrav ved Brendore Mølle (P 2) viser den c. $10 \mathrm{~m}$. høje Væg øverst $1 \mathrm{~m}$. sandet Moræneler og derunder vekslende Sand- og Gruslag af $2-3 \mathrm{dcm}$. Tykkelse. Disse Lag ere stærkt foldede, blandt andet ses de ørerste, i Profilets Vestende temmelig horizontale Lag at bøje omtrent lodret nedad for i Foden af Vreggen atter at ligge omtrent vandrette.

Diluvialsandets Kornstørrelse er yderst varierende, det hører til Sjældenhederne at finde nogenlunde ensartet Sand gennem en Væg paa nogle faa Meters Højde. Som Regel er Diluvialsandet kalkholdigt, naar undtages de øverste, udvaskede Lag, og i mange Tilfælde giver Kalkholdigheden sig umiddelbart til Kende ved de talrigt forekommende Kridtbryozoer.

Størst Betydning har Diluvialsandet (i Forbindelse med Diluvialgruset) som vandførende Lag, og da disse fluvioglaciale Lag som Helhed ligge temmelig regelmæssigt indenfor Kortbladsomraadet, vil man ogsaa - hvor der ikke stilles for store Fordringer til Vandmængden - have let ved at skaffe Vand. Hvor Sandet i Bakketoppe hæver sig højt over Omgivelserne, er det selvfølgelig tørt eller yderst vandfattigt. Dette er f. Eks. Tilfældet paa Skamlingsbanke. Til Gengæld forøge saadanne højtliggende Sandpartier Grundrandets Stighøjde paa det omgivende Lavland, saaledes Syd for Skamlingsbanke, hvor man i Terrainet omkring Hejls som Regel faar Springkilder ved at bore gennem det over Sandet liggende, mægtige Lag Moræneler. Hvor Diluvialsandet i Klinter eller Skrænter hviler paa Diluvialler eller Moræneler, findes ofte naturlige Kildevæld.

\section{Lagdelt Diluvialgrus.}

Det lagdelte Diluvialgrus optræder næsten altid i Forbindelse med Diluvialsandet, oftest som tynde Lag i dette, sjældnere og kun lokalt som en saa betydelig Del af de fluvioglaciale Aflejringer, at det faar praktisk Betydning.

Øst for Lillebelt findes Diluvialgruset temmelig sparsomt; i det Sandparti, der kommer frem langs Vibymølle Aa (L 3), ses af og til Gruslag, saaledes Nordvest for Rodlund. Lejringsforholdene ere paa disse Steder temmelig regelmæssige. I den høje Bakkeryg mellem Tybrind Skov og Fyns ere Gruslag sjældne, Sandet er gennemgaaende fint og stenfrit. I Fortsættelsen mod Nordvest paa Halvøen 
Fynsskov kommer Diluvialgruset frem et Par Steder, saaledes Nord for Tønnæs og Syd for Ellegaard. Begge Steder ere Lejringsforholdene regelmæssige; Nord for Tønnæs gaar Gruset udækket til Overfladen i en lille Bakketop; Syd for Ellegaard viser Profilet i den henved $10 \mathrm{~m}$. høje Skrænt: øverst sandet Moræneler eller Morænesand, derunder temmelig horizontalt lagdelt Diluvialsand og Diluvialgrus i vekslende Lag, og i Klintens Fod uforvitret, haardt Moræneler. Vegetation og Skred umuliggiorde en nøjagtig Undersøgelse af Klinten, men det syntes, som om det øvre og det nedre Moræneler smeltede sammen baade mod Nordvest og mod Sydøst, saaledes at de fluvioglaciale Dannelser paa dette Sted optræde som et stort Indlag i Morænen.

Syd for Tybrind er Diluvialgruset sjældent; hvor det findes, er det kun som tynde Lag i Diluvialsandet, saaledes f. Eks. i Foden af den høje, halvcirkelformede Klint „Hulen“, Nord for Husby Kirke (L 2). Ogsaa paa Øerne i Lillebelt optræder Diluvialgruset meget sparsomt, oftest som ubetydelige Lag i Sandet.

Paa Kortbladets jydske Del findes Diluvialgruset noget hyppigere, dog maa hele det nordøstlige Parti siges at være ualmindelig fattigt paa Grus og Sten. I Skrænterne langs Solkjær Aa træder Diluvialgruset frem et Par Steder, saaledes Vest for Bjært, ved Bindrup Vandmølle og Vest for Bindrup By (O 3). Ved Bindrup Vandmølle vise de $3 \mathrm{~m}$. høje Profiler et $1 / 2-1 \mathrm{~m}$. tykt Dække af Moræneler over horizontalt lagdelt Diluvialgrus med Sandlag. Gruset er her temmelig groft med Sten som Eg eller en knyttet Haand.

I Højdedraget omkring Skamlingsbanke optræder Diluvialgruset ret almindeligt, og paa flere Steder viser det sig i Overfladen, der da er meget rig paa Smaasten. Dette er f. Eks. Tilfældet paa den østlige Skraaning ved Odderbæk og ved Bankens Nordende. Paa sidstnævnte Sted, Sydøst for Bindrup, ses uforstyrret lagdelt, graat og bryozoholdigt Diluvialgrus, der dækkes af en tynd Kappe af udvasket Moræneler, meget rigt paa Smaasten. Paa Bakkeskraaningen Nord og Nordøst for Grusgraven bestaar Jordbunden af Diluvialgrus, der gaar udækket til Overfladen.

Oppe paa selve Ryggen af Skamlingsbanke, tæt Nord for Mindestøtten, ses i nogle smaa Sand- og Grusgrave graahvidt, fint Grus med ærtstore Kvartskorn, blandet med hvidt Kvartssand. I det ene af Profilerne viser Kvartssandet en tydelig diskordant Parallelstruktur, i det andet mangler det Lagdeling; begge Steder dækkes det af et tyndt Lag Moræneler. Kvartssandet og Kvartsgruset stammer utvivlsomt fra tertiære Lag og synes nu at ligge som Indlag i det almindelige Diluvialsand. I alt Fald har man nede i Bakkens Fod, Sydvest for Støtten, fuldstændig bortgravet et saadant Grusparti, hvor 
Lagene vare meget stejltstillede, og hvis Grænser mod det omgivende, gule Diluvialsand vare næsten lodrette.

I Terrainet Vest paa optræeder Gruset oftest i Forbindelse med Diluvialsandet og med lignende Lejringsforhold som dette. I den store Grusgrav ved Aastorp ligge Lagene af Sand og Grus overordentlig regelmæssige og uforstyrrede; Profilet er nærmere omtalt Side 53. I en Grusgrav i Nordranden af Istak Mose ere Lagene skraatstillede, men iøvrigt hverken foldede eller sammenpressede. I enkelte Tilfælde kan Kornstørrelsen veksle overordentlig stærkt, saaledes at man i samme Profil finder vekslende Lag af groft Grus og meget fint Sand, mellem hvilke der kan træffes tynde Lag af stenfrit Ler.

Betydelige Mængder af Diluvialgrus findes i Egnen mellem Taps Kirke og Frederikshøj Kro (P 2). Tæt Nord for sidstnævnte Sted, paa Østsiden af Haderslev-Landevej, ses i en stor Grusgrav et indtil $7 \mathrm{~m}$. højt Profil; øverst findes fra $1 / 2$ til $2 \mathrm{~m}$. stenet Sand, derunder $1 / 2-1 \mathrm{~m}$. Moræneler og nederst Diluvialsand og Diluvialgrus i meget regelmæssige Lag. I en Grusgrav Vest for Vejen er Væggen $6 \mathrm{~m}$. høj og viser øverst $1 \mathrm{~m}$. Moræneler og derunder Diluvialsand og Diluvialgrus i stærkt foldede Lag. I en nu udjærnet Grusgrav lidt nordligere fandtes øverst henved $1 \mathrm{~m}$. sandet Moræneler, derunder $1 / 2-1 \mathrm{~m}$. fedt Moræneler, hvis Underflade var meget uregelmæssig, og derunder Diluvialsand og Diluvialgrus i svagt bølgede, men gennemgaaende vandrette Lag. Af Forholdene paa Stedet og af Boringen ved Frederikshøj Kro (Boring XX) synes det at fremgaa, at Diluvialgruset i dette Terrain har stor Udbredelse; det graves dog kun paa Steder, hvor det dækkende Moræneler har ringe Mægtighed. Ogsaa Diluvialgrusets Mrgtighed er meget betydelig, i de ovenfor omtalte Grusgrave er den mindst $8-9 \mathrm{~m}$. og ved Frederikshøj Kro $15,6 \mathrm{~m}$.

I Egnen omkring Tapsore (P 2) findes adskillige Profiler i de fluvioglaciale Lag, men paa de fleste Steder er Gruset temmelig fint og udgør kun en ringe Del af den samlede Masse. Vest og Nordvest herfor mellem Fovslet og Brendore, ere Diluvialgrusets Lejringsforhold - ligesom Diluvialsandets - mere uregelmæssige, samtidig med at det dækkende Moræneler veksler stærkt i Mægtighed. Profilerne i Grusgraven Nordøst for Brendore ere tidligere omtalte (Side $55)$; i en anden stor Grusgrav tæt derved dækkes Gruset og Sandet af Moræneler, hvis Magtighed i de forskellige Sider af Graven varierer fra $1 / 2$ op til $4^{1} / \mathrm{g}$. Profilet i Grusgraven ved $\varnothing$ dis, Sydvest for Tagkjær, hvor Diluvialgruset dækkes af Morænegrus og optræder i Forbindelse med Moræneler, der som Bænke ligger inde mellem Gruslagene, er tidligere beskrevet (Side 33). 
Det vil af det foregaaende fremgaa, at Diluvialgruset, der har stor Værdi som Vejmateriale, altid optræder i Forbindelse med Diluvialsandet, at det i de færreste Tilfælde udgør en saa stor Del af den samlede Masse, at det kan lønne sig at bearbejde det, og at dets Forekomstmaade er meget lunefuld, saa at man vanskeligt indenfor Kortbladet Skamlingsbankes Omraade forud vil kunne paapege Steder, hvor det kan findes. Som oftest dækkes Gruset af Morænedannelser af meget varierende Mægtighed. Stenenes Størrelse er i Reglen som Nødder eller Eg, ret ofte kunne dog enkelte Bænke i Gruset bestaa af Sten som en knyttet Haand, men større, rullede Sten ere sjaeldnere.

Stenarterne i Diluvialgruset ere omtalte tidligere under "de løse Blokke", og de i Gruset fundne Skalfragmenter ere nævnte samme Steds Side 44. 


\section{Senglaciale Aflejringer.}

Senglaciale Ferskvands-Aflejringer Ler, Sand og Grus, findes ret almindeligt indenfor Kortbladsomraadet. De ere paa det nøjeste knyttede til Terrainformerne og forekomme som Udfyldninger i flade Bassiner eller i Bunden af Dale og Kløfter.

Øst for Lillebelt optræder senglacialt Ler over store Arealer Nord for Viby i Kortets Nordrand. De udfylde her nogle flade Lavninger i det c. $20 \mathrm{~m}$. over Havet liggende, bølgede Moræneler-Landskab. Gaar man fra de omgivende Bakker ned over et af disse Bassiner, vil man i mange Tilfælde nærmest Randen finde stenfrit Sand, der hviler paa Moræneleret, og som længere ude overlejres af stenfrit Ler; over dette kan der undertiden atter ligge et tyndt Sandlag eller alluviale Tørvemoser; men lige saa ofte hviler det senglaciale Ler direkte paa Moræneleret, og Sandet mangler. Karakteristisk for disse Dannelser er foruden deres Afhæengighed af Terrainet tillige deres regelmæssige og uforstyrrede Lejringsforhold; de indeholde ikke større Sten og ere ikke dækkede af nogen Moræenedannelse. Grænsen mod det omgivende Højland er med smaa Afvigelser næsten horizontal og angiver direkte den tidligere Søbred.

Ved Teglværket Nordøst for Viby findes Profiler i de senglaciale Lag. I Lergraren ses øverst 0,5 m. stenfrit, senglacialt Sand, derunder horizontalt lagdelt, stenfrit, senglacialt Ler med tynde Sandlag; Mægtigheden varierer fra 0,5 til 2,4 m.; derunder groft Sand. Leret er øverst gult, nederst graat og temmelig sandet; i det nederste Parti findes enkelte Skaller af en stor Limnaa, men derimod ingen Planterester. I Teglværkets Brønd er Lagserien følgende: 0,6 m. Muld og senglacialt Sand, derunder 1,3 m. senglacialt Ler, derunder $0,6 \mathrm{~m}$. senglacialt Sand og nederst Moræeneler, hvori man har boret henved $4 \mathrm{~m}$. uden at naa derigennem.

I det vestlige af disse senglaciale Bassiner, i hvilket der Nord for 
Banelinien findes en temmelig dyb Tørvemose, Kosmose, er der i Følge velvillig Meddelelse fra Distriktslæge Dreyer, Ringsted, fundet et Stykke af en Rensdyrtak - "nederste Del af venstre Stang med afbrudte Takker". Takken fandtes ., i Leret under Tørven tæt ved Land". Den opbevares nu i Distriktslæge Dreyers Samling.

En lignende Lavning, der er udfyldt med sandet, senglacialt Ler, og som derfor nu viser sig som en plan Slette, omgivet af bølget Moræneterrain, findes tæt Nordøst for Ubby.

Ogsaa Vest for Lillebelt træffes ret almindeligt Bassiner udfyldte med senglacialt Ler og Sand. Saaledes findes mellem Morænelerbakkerne Øst for Hejls Kirke en Lavning, der aabenbart tidligere har været en Sø med Udløb mod Sydvest. I Lavningens vestlige Side (i Søens "Læside“) er der aflejret lagdelt, stenfrit Ler, hvis dybere Lag ere graa og mangle indblandet organisk Stof, hvorimod de øvre Lag ere mørkere farvede og gaa over i leret, alluvialt Dynd. I senere Tider er Lavningens østlige Del bleven udfyldt med Tørv.

Lignende Lavninger, udfyldte med graat, stenfrit Ler, findes blandt andet $1^{1} / 2 \mathrm{~km}$. Øst for Taps Kirke, Syd for Vejstrup Kirke, Øst for Svanmose og ved Fovslet. Et lille fladt Bassin med senglacialt Ler findes Nord for Vonsild, tæt Vest for Landevejen; Leret dækkes mod Sydvest af alluvialt, planteholdigt Ler med Tørvelag. I Nærheden af Vonsild By har J. P. J. Ravn tidligere i en lille Lavning fundet senglacialt Ler med Blade af Betula nana og Salix reticulata ${ }^{1}$ ). Leret dækkes af alluvial Gytje og Tørv.

Af Interesse er endvidere Forekomsten af senglaciale Aflejringer i Svanmose, Dridekjær og de Øst derfor liggende Moser, (P 3, 2). Disse store Lavninger have aabenbart tidligere været Søer, men ere nu for største Delen udfyldte med Tørv; kun ved Randene komme de senglaciale Lag udækkede frem. De bestaa her ikke alene af Ler og Sand, men ogsaa af Grus, der optræder som smaa Strandvolde, i Særdeleshed paa Lavningernes Ost- og Nordøstside. Stenene i Gruset ere ært- til valnøddestore, Lagdelingen er meget utydelig. Blandt de bedst udviklede af disse Indsø-Strandvolde kan nævnes dem langs Randen af Svanmose samt en iøjnefaldende Grusvold i Nordøstsiden af den store Mose Øst for Dridekjær (P 2); denne sidste Strandvold afspærrer en Del af Mosen og løber i en Bue tværs over den nuværende Fovsaa.

Ret udbredte ere endvidere senglaciale Lag i Dalene og langs Vandløbene, men det er i mange Tilfælde vanskeligt paa saadanne Steder at trække en Grænse mellem æeldre (senglaciale) og yngre

1) N. Hartz: Bidrag til Danmarks senglaciale Flora og Fauna. D. G. U. II. Række. Nr. 11. Kjøbenhavn 1902. Side 49. 
(alluviale) Aflejringer, idet deres Dannelse er fortsat uafbrudt, omend betydeligt langsommere, lange efter, at Landisen var smeltet bort fra denne Egn.

Omkring det største af de nuværende Vandløb, Solkjær Aa, findes senglaciale Aflejringer af meget forskellig Art. Aaen kommer, som det ses af Kortet, fra Grundinghoved Mose ved Sydvestsiden af Skamlingsbanke. Ned til Mosen fører oppe fra Højdedraget en kort, dyb Kløft med stejle Sider; den kan ikke være udgravet af noget nuværende Vandløb eller Kildevæld, - Kløften er fuldstændig tør - men maa skyldes en Gletscherelv, der er styrtet ned her, da Isranden stod ved Skamlingsbankes Ryg. Sandet i Kløften er groft, lyst, senglacialt Sand. Grundinghoved Mose har stejle Sider og er nu fuldstændig fyldt med Tørv; ligeledes viser Aadalen Nordvest herfor indtil Damkjær Gaard stejle Sider og en bred, temmelig plan Bund. Hvor Dalen er smallest, ses de senglaciale Lag, Ler, Sand og Grus; Leret er aabenbart yngst, det ligger direkte under Dyndet og Tørven ude i Mosen og maa være aflejret paa en Tid, hvor Afløbet laa saa højt, at Mosen var omdannet til en Sø. Sandet og Gruset danner smaa, utydelige Terrasser, mellem hvilke det nuværende Afløb har skaaret sig ned. Fra Damkjær Gaard til Bindrup Vandmølle følger Aaen en naturlig Sænkning i Terrainet, men videre Nord paa antager Dalen igen en udpræget U-Form. Siderne bestaa af Moræeneler eller Diluvialgrus, Dalbunden er ikke fugtig Eng, men en plan, fast Mark, der bestaar af senglacialt Sand, dækket af et muldet Lag af fedt, senere nedskyllet Ler. Selve Aaen løber i en 2-3 m. bred Rende.

Fra det Punkt, hvor Solkjær Aa drejer Øst paa forbi Bjært og Stendrup, strækker der sig en Dal med det ovenfor nærnte U-formede Trærsnit mod Nordvest forbi Skartved. Vandløb findes ikke i denne Dal, Bunden bestaar af leret, senglacialt Sand, enkelte Steder af skarpt, groft Sand, og kun paa Steder, hror Hældningen er srag, ere de senglaciale Lag dækkede af Ferskvands-Alluvium. Dalen er ikke udskaaret af noget Nutids-Vandløb; dens Dannelse maa staa i Forbindelse med Indlandsisens Afsmeltning og skal omtales senere.

Langs Solkjær Aa, fra Bjært Øst paa til Stendrup, ere Dalsiderne temmelig stejle, Dalen er bred, og dens Bund er for en stor Del udfyldt med senglaciale Aflejringer. Nord for Bjært findes nede i Dalen vandret lagdelt, lysegraat, groft Sand med Lag af fint Grus; derover ligger et Lag Ferskvandsler, hvis Mægtighed veksler fra $1 / 2$ til et Par Meter. Dette Ler er i vaad Tilstand mørkegraat; naar det tørrer og ligger pløjet op i Markerne er det lysegraat, haardt og smuldrer i smaa skarpkantede Brokker. Det kan vistnok betragtes som en Overgangsdannelse mellem de senglaciale og de alluviale Lag; da det 
imidlertid er væsentlig forskelligt fra de alluviale Ferskvandsaflejringer, der almindeligt forekomme i Aadalene, er det paa det geologiske Kort betegnet som senglacialt.

Ind mod Dalens Sider og et Stykke op ad disse findes senglacialt, groft, smaastenet Sand; Nord for Bjært er der en Antydning af en Terrasse, og Sandet naaer her samt længere Vest paa op til en temmelig konstant Højde, $16-18 \mathrm{~m}$. o. H., medens det mod Øst ligger betydeligt lavere.

Sydøst for Stendrup, hvor Aadalens Sider ere lave og flade, og hvor største Delen af Dalen er udfyldt af Ferskvands-Alluvium, findes atter den ovenfor omtalte Overgangsform mellem senglacialt Ler og alluvialt Ferskvandsler; det ligger som en Bræmme langs Dalens Nordside og strækker sig ud under Ferskvands-Alluviet. Det senglaciale Sand optræder her kun som lave, isolerede Banker ude i Dalen.

Ogsaa langs andre af Aaerne findes senglaciale Aflejringer, i Reglen Sand, undertiden smaastenet, oftest dog lerholdigt, men uden at det er muligt at trække en skarp Grænse mellem de utvivlsomt senglaciale Aflejringer og det senere nedskyllede eller af Aaen flyttede Materiale.

Ret udbredt er det senglaciale Sand langs Taps Aa mellem Aastorp og Taps Kirke; her er det dog oftest dækket af et tyndt, alluvialt Ferskvandslag, og kun paa enkelte Strækninger, som f. Eks. mellem Istak Mose og Aastorp, er selve Dalen af utvivlsom glacial Oprindelse.

Med typisk U-Form optræder Sest Aaens Dal fra Vonsild (P 3) Nord paa til Kortbladets Grænse; Siderne ere overordentlig stejle og Dalbunden temmelig plan. Den bestaar af Sand og Grus med indtil ægstore Sten; her er dog, ligesom i de fleste andre Dale, det øverste Lag leret, mørktfarvet af Planterester og rimeligvis nedskyllet i senere Tider. Enkelte Steder rage smaa Banker af det underliggende Moræneler frem, paa andre Strækninger er der aflejret Tørv i Fordybningerne i de senglaciale Lag.

Ogsaa den smalle, dybt nedskaarne Dal Vest for Dalby Kirke maa for en Del betragtes som en senglacial Flodrende, og det i Dalens Bund aflejrede Sand som delvis senglacialt. 
Som allerede omtalt indeholder det øverste Diluvium i denne Egn kun faa Stenarter, der ere transporterede hertil fra Nord. Største Delen af de erratiske Blokke hidrøre fra Østersøbassinet, dels fra Ostersøens Bund, dels fra dens Kyster, og ikke alene fra den svenske Kyst, men ogsaa fra de russiske Østersøprovinser. Den sidste Indlandsis, der dækkede det her beskrevne Omraade, maa derfor i Hovedsagen have fulgt Østersølavningen og fra Sydøst og Østsydøst være naaet op over Egnen ved Lillebelt.

Over største Delen af Kortbladsomraadet maa Landisens Afsmeltning og Israndens Tilbagerykning være foregaaet meget jævnt. Paa et Par Steder er der dog Sandsynlighed for, at Isranden - der i det store og hele har ligget vinkelret paa Bevægelsesretningen - har været stationær i længere Tid, maaske endog er rykket noget frem.

Det synes, som om Landisens Bevægelsesretning i den vestlige Del af Kortbladet (og Vest derfor) har været omtrent fra Øst til Vest, idet Israndslinierne dér næsten have Retningen Nord-Syd. Eftersom Isen smeltede bort og Isranden flyttedes Øst paa, har Berægelsesretningen ved Randen rimeligvis ændret sig mere og mere til ØSØ.VNV., og paa den fynske Del af Kortbladet tyde Terrainformerne paa en Bevægelse næsten fra Sydøst til Nordvest.

Den vestligste Israndslinie, der kan paavises paa Kortbladet Skamlingsbanke, findes i Kortets Vestrand. Da den delvis ligger inde paa det tilstødende Kortbladsomraade og staar i nøjeste Forbindelse med udbredte Smeltevandsaflejringer længere mod Vest, ved Hjælp af hvilke dens Karakter træder tydeligt frem, bør den ved en anden Lejlighed omtales i Forbindelse med disse. Her skal da kun nævnes, at der Sydvest for Tagkjær (P3) ved Byen Ødis maa have staaet en stor Gletscherport, hvorfra Vandmasserne ere strømmede ud Vest paa og have dækket et stort Terrain med Sand. Netop her ved Ødis findes det Side 33 omtalte, for en Israndsdannelse typiske Profil, hvor Morænegrus overlejrer fluvioglacialt, lerholdigt Grus med mellemliggende Bænke af Moræneler. Imod Nord er der ved Isranden dannet et stort, bredt Endemoræneparti paa begge Sider af Kortbladgrænsen; nordligst er det dog bedst udviklet Vest for denne Grænse. Det bestaar hovedsagelig af Moræneler, af meget vekslende Mægtighed og ofte med en stærkt bølget Overflade. Paa mange Steder, som f. Eks. i Egnen ved Fovslet Skov, er Leret dækket af talrige store Sten. 
Nærmest Syd for Ødis har Isranden staaet som Bue mod Sydvest og Syd, hvor dens Plads kendetegnes ved et Vest for Kortbladgrænsen liggende System af prægtige, bueformede Bakkerygge, der for største Delen bestaa af Sand og Grus.

Øst for denne Israndslinie ligger det lave, jævne Terrain, der fra Sest Skov og Vonsild strækker sig mod SSV., og hvis dybeste Partier, Svanmose, Dridekjær, o. s. v., nu ere Tørvemoser.

Isranden maa over dette Terrain være rykket meget jæunt Øst paa; først Øst for Svanmose og Sest Skov synes der igen at have været en Stansning. Et meget uroligt og smaatoppet Morænelandskab langs den Vej, der fra Vonsild fører mod SSV. til Hoppes Gaard og Kransbjerg Gaard (P 3) tyder paa, at Isranden har ligget her i nogen Tid. Desuden sker der ved Vonsild By en paafaldende Forandring i Sest Aaens Dal, der fra en ubetydelig Rende pludselig udvider sig til en bred Dal med stejle Sider og af samme Type som de store jydske Smeltevandsdale. Nord for Kortbladgrænsen, hvor Sest Aaen løber mod Nordvest gennem en dybt nedskaaren Dal med mere end $30 \mathrm{~m}$. høje Brinker, faar man et endnu tydeligere Indtryk af Dalens glaciale Oprindelse.

Mellem Kolding-Haderslev Landevej og Lillebelt er Israndens Beliggenhed i en kortere Tid rimeligvis angivet ved den Lavning, hvorigennem Solkjær Aa løber fra Damkjær Gaard til Ajtrup (O 3). Noget østligere kan der dog paavises en langt smukkere, men ganske vist meget kort Israndslinie, nemlig Skamlingsbanke-Ryggen. Med en Længde af et Par Kilometer og Retning mellem N.-S. og NNØ.SSV. hæver dette Bakkeparti sig højt over Omgivelserne og minder paa Afstand om en uhyre Hval. Mod Vest staar Bakkeranden renest, og Hældningen er størst (se Fig. 8, Side 63). Mod Øst er den egentlige Bakkeryg ikke saa skarpt afgrænset; mellem den og Lillebelt findes et uregelmæssigt og meget bakket Terrain, hvis Højde lidt efter lidt aftager ned mod Stranden (se Fig. 1, Side 3 og Fig. 9-10, Side 65). Vest for selve den høje Ryg findes der mod Nord en lavere Ryg, der strækker sig hen mod Bindrup By, og hvis Vestskrænt ogsaa er temmelig stejl. Saavel denne Ryg som den egentlige Skamlingsbanke bestaar - som tidligere næunt — rimeligvis for den langt overvejende Del af fluvioglaciale Lag, Sand og Grus, der optræde saavel med meget regelmæssig som med forstyrret Lagdeling. Over en Del af den højeste Ryg ligger der en tynd Kappe af Moræneler, og i det stærkt bølgede og bakkede Terrain Øst derfor spiller Moræneleret Hovedrollen.

Medens den høje Skamlingsbanke-Ryg maa betragtes som en Randmoræne, aflejret foran og under Isranden, og opbygget af det Sand og Grus, som Smeltevandsfloderne førte frem hertil, er det bakkede 




Danmarks geologiske Undersøgelse. I. R. Nr. 12. 


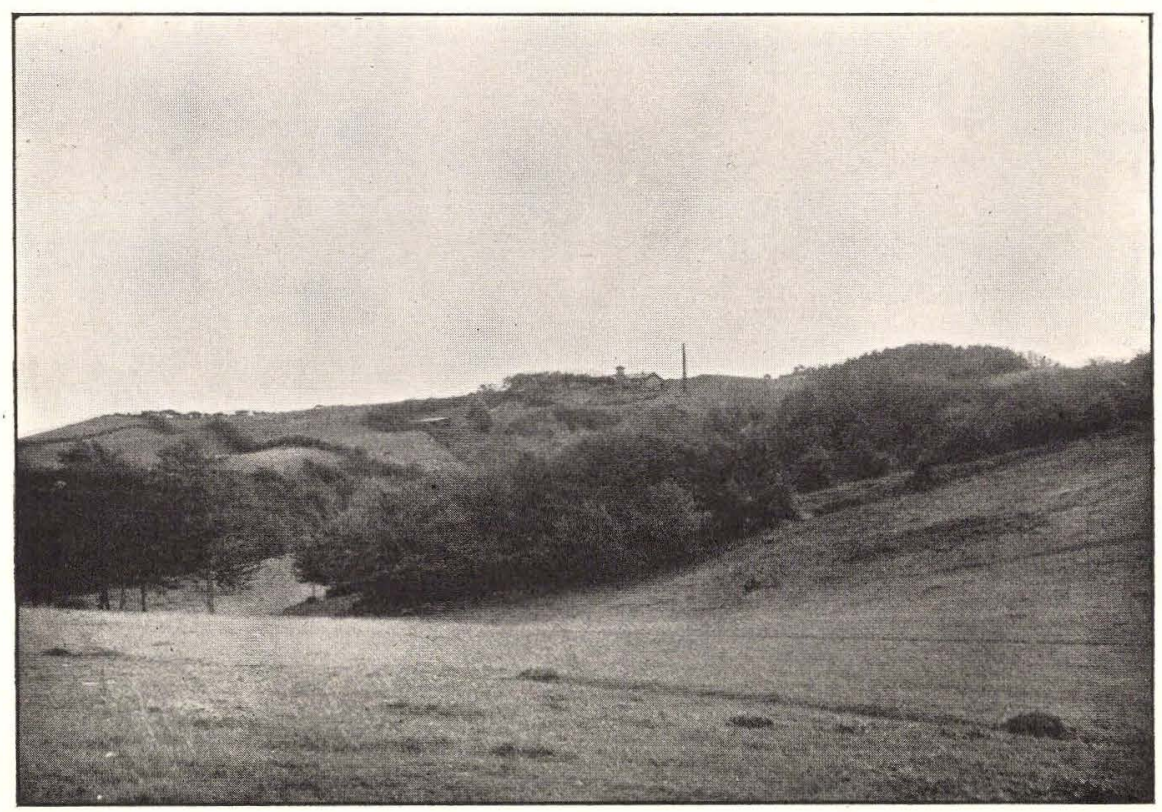

Fig. 9. Skamlingsbanke set fra NØ.

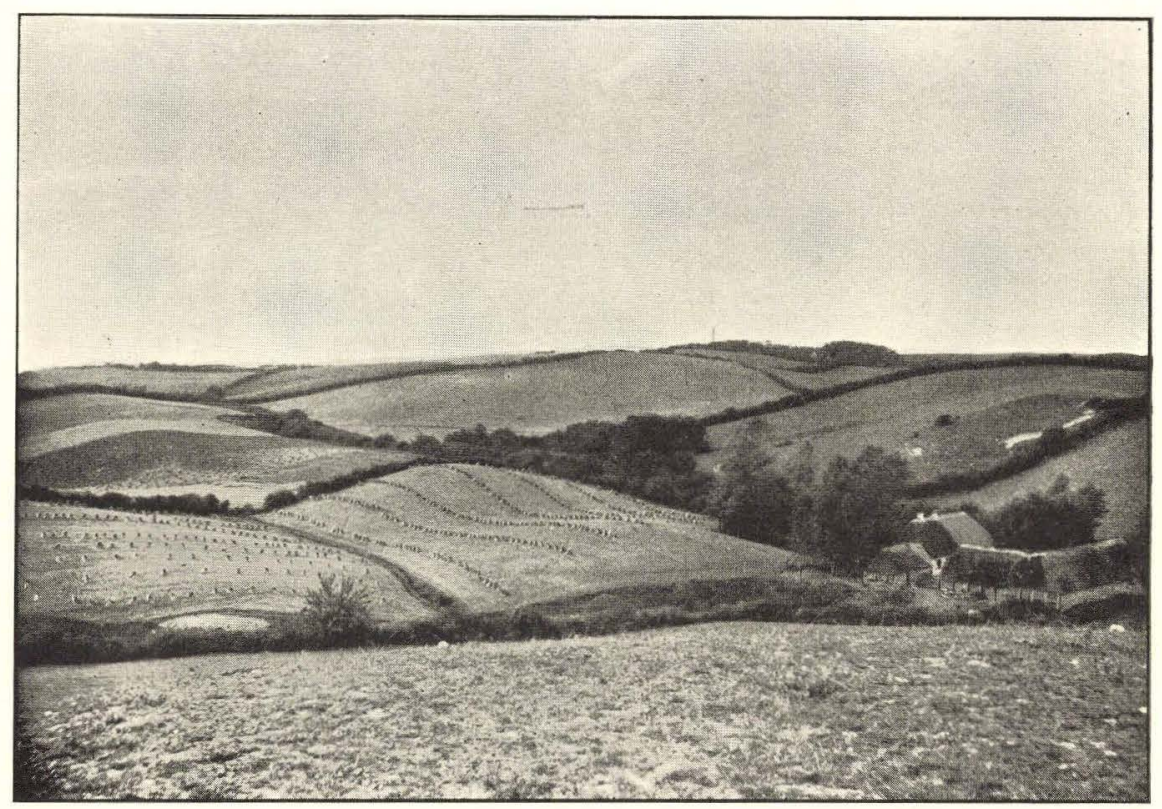

Fig. 10. Skamlingsbanke set fra Sø. 
Lerterrain Øst derfor et Endemorænelandskab, hvori Materialet dels er fluvioglacialt, dels ført frem og aflejret som Isens Bundmoræne, altsaa i Hovedsagen subglacialt og til Dels samtidigt med Randmorænen Vest derfor. Dybe Render, som f. Eks. Kløften langs Odderbæk, der nede fra Mosvig kan følges gennem det bakkede Endemorænelandskab omtrent til Skamlingsbankes højeste Punkt, angive Stedet for de subglaciale Flodløb, der førte Materialet frem til Isranden.

Endnu en Israndslinie kan maaske trækkes indenfor selve Skamlingsbankepartiet, nemlig langs den temmelig stejle Skrænt, der fra Strandskov kan følges mod NNV. til den indre Ende af Vindemose. Denne Linie danner Grænsen mellem det bakkede Morænelandskab mod Vest og en ret jævn, noget skraanende Flade mod Øst. Den store Forskel i Terrainformerne og denne Linies tilsyneladende horizontale Forløb bringer Tanken hen paa en mellem Landisen og de høje Bakker opdæmmet Sø; men det er næppe rigtigt. "Strandlinien" er ikke fuldstændig vandret, men stiger fra knap $30 \mathrm{~m}$. o. H. mod Syd til omtrent $40 \mathrm{~m}$. mod Nord. Mod Nord bestaa Bakkerne af Sand og Fladen af fedt Moræneler, mod Syd ere Bakkerne Moræneler, medens der paa Fladen findes Grus og Sand, paa enkelte Smaapletter dækket af lidt Morænesand. Endelig er den skraanende Flade ikke fuldstændig jævn, men smaabølget, og de glaciale Render, der føre op til Skamlingsbanke-Ryggen ere lige saa skarpe og velbevarede paa Fladen som oppe mellem Bakkerne. Hvorledes denne ejendommelige Flade er opstaaet er uvist. Mulig bør Sandet og Gruset dér betragtes som subglacialt, og saaledes, at de store Vandmasser, der her pressedes frem mod Isranden, have bevirket, at Overfladen har faaet et Udseende, der paa flere Maader minder om en Søbund.

Medens der indenfor den Bugt, Mosvig, der maaske skylder Isens Erosion sin Oprindelse, er ophobet saa store Israndsaflejringer, er det ikke muligt at paavise Fortsættelsen deraf, hverken mod Nord eller mod Syd; begge Steder findes et jæunt Moræneler-Terrain, der ikke i nogen Henseende afviger fra Omgivelserne.

Udenfor Isranden maa største Delen af Smeltevandet være søgt bort gennem den nuværende Solkjær Aa. Noget er rimeligvis løbet fra Skamlingsbankes Nordende mod Nordvest; i Bindrup By har det udgravet en smal Lavning og Vest derfor aflejret et forholdsvis tyndt Sandlag over Moræneleret, der her skraaner jævnt ned mod Aaen. Fra Skamlingsbankes Sydvestside fører en dyb Erosionskløft ned til Grundinghoved Mose, der selv ligger temmelig dybt i Forhold til Omgivelserne. Fra dette Sted har Smeltevandet udgravet en bred U-formet Dal i nordlig Retning. Men medens Solkjær Aa nu ved 
Ajtrup drejer skarpt Øst paa og flyder til Lillebelt, maa denne Vej have været stoppet paa det Tidspunkt, da Isranden stod ved Skamlingsbanke-Linien, og da den mod Nord rimeligvis har skaaret Solkjær Aa Dalen ved Stendrup eller mellem dette Punkt og Bjært.

Allerede tidligere, da Isranden stod ved Ajtrup-Bjært, maa Smeltevandet fra Isranden have udgravet den Side 61 omtalte glaciale, U-formede Dal, der fører mod Vest og Nordvest forbi Skartved, og i hvilken der indenfor Kortbladsomraadet ikke findes noget Nutidsvandløb. Dalbunden, der bestaar af Sand, delvis dækket af Alluvium, stiger fra $10 \mathrm{~m}$. mellem Bjært og Ajtrup til $20 \mathrm{~m}$. o. H. ved Skartved, og først herfra er der et jævnt Fald mod Nordvest og Nord til Kolding Fjord. I den Tid, da Isranden stod ved Bjært og efterhaanden rykkede tilbage mod Øst til Stendrup, maa der altsaa i Solkjær Aa Dalen være sket en Opstemning af Vandet til mindst $20 \mathrm{~m}$. o. H. Vidnesbyrd herom findes ogsaa i det senglaciale Sand, der - i Særdeleshed Nord for Bjært — dækker Dalens Sider omtrent op til denne Højde.

Paa et endnu senere Tidspunkt, da Isranden stod ved Mundingen af Solkjær Aa, har største Delen af Smelterandet kunnet søge bort langs den nuværende Kyst, og i Solkjær Aa Dalen har der kun været en ringe Opstemning af Vandet. Rimeligvis fra denne Tid stammer en Del af det lavtliggende, senglaciale Ler mellem Bjært og Lykkesgaard.

Øst for Lillebelt er der indenfor Kortbladgrænsen ikke paavist tydelige Israndslinier. Mulig kunne de to langstrakte Lavninger, der Nord for Viby (L 3) strække sig i NNO.-SSV., angive Opholdslinier for Isranden. De ere nu, efter at være udfyldte med senglacialt Ler og Sand, ikke synderlig fremtrædende i Terrainet. Derimod synes - som tidligere berørt - Landskabsformerne i det hele taget at staa i Forbindelse med og delvis være en Følge af Indlandsisens Bevægelse fra ØSØ. til VNV., samt af Isens og Smeltevandets forenede eroderende og accumulerende Virksomhed. Selv om disse Rygge og Larninger skulde have deres Oprindelse i lignende Uregelmæssigheder i den tertiære Undergrund, hvad der dog ikke er noget, som tyder paa, vilde Terrainformerne næppe være blevne bevarede, saafremt Landisen ikke netop havde haft den angivne Bevægelsesretning, parallel med Ryggenes Strygningsretning.

Som Eksempel paa Lavninger, udgravede af Landisen, eller gennem hrilke Isen har bevæget sig efter deres Længderetning, er den indre Del af Gamborg Fjord typisk. I denne Del, der delvis optages af Fynsvang, er Bunden næsten overalt fedt Moræneler; fluvioglacialt Materiale ses saa godt som slet ikke, der findes ingen. Mærker efter Flodrender, og mod Øst afsluttes Lavningen i jævne, afrundede For- 
mer, det almindelige Moræneler-Terrain. Dale udgravede af Smeltevandet fra Isen er f. Eks. den smalle, dybe Kløft Øst for Hovedsø, indenfor Fyns Vig, endvidere en kort, men dyb Erosionskløft i Tybrind Skov Syd for Landevejen (den staar maaske i Forbindelse med den Side 52 nævnte Rullestensaas tæt Øst herfor, umiddelbart Ost for Kortbladgrænsen), og endelig den Kløft, der Nord for Husby Kirke fører ud til Tybrind Vig. I sidstnævnte Kløft bestaar Bunden ganske vist af Moræneler, men Vidnesbyrd om tidligere Vandløbs Erosion ses dog i Skrænterne paa Sydsiden af Kløften, saaledes i den c. $20 \mathrm{~m}$. høje, stejle, halvcirkelformede Skrænt "Hulen" Nord for Husby Kirke, samt paa Nordsiden af Sobjerg, en isoleret, drumlinlignende Morænelerbanke Nord for Husby. 


\section{Alluviale Aflejringer.}

\section{A. Saltvandsaflejringer.}

Det marine Alluvium indtager kun et ringe Areal paa Kortbladet Skamlingsbanke. Som bekendt ligger denne Egn Sydvest for den Linie, der allerede af Forchhammer bestemtes som Sydgrænsen for det alluviale Hævningsomraade. Hvorledes Niveauforholdene have været i senglacial Tid kort efter Landisens Bortsmeltning vides ikke med Bestemthed; utvivlsomt har Landet dog ligget adskilligt højere end nu. I det første Afsnit af den alluviale Tid maa det samme have været Tilfældet; men derefter indtræder en Landsænkning, der i denne Egn er fortsat uafbrudt rimeligvis indtil nyeste Tid. Hvad man kan finde af marine Lag, er derfor enten meget unge Stranddannelser, eller Fjorddannelser, der ved Kunst ere tørlagte. Lag, der oprindelig aflejredes under Havet, findes ikke noget Steds indenfor Kortbladsomraadet hævede op over Havet, tværtimod maa man antage, at de - i Særdeleshed de ældre - yderligere ere blevne sænkede.

Stranddannelser ere lidet udviklede og findes i Reglen kun paa Steder, der ligge aabne og ubeskyttede ud mod Lillebelt. Veludviklede Strandvolde med godt rullede Strandsten ses saa godt som slet ikke, og adskilligt af det, der paa det medfølgende geologiske Kort er aflagt som Strandgrus, er kun Sten og Grus, der ere udvaskede af de glaciale Dannelser, og af Bølger og Strøm ført et Stykke bort og dér aflejrede sammen med Strandsandet. Saadanne Aflejringer findes f. Eks. paa Svinø, hvor det stærkt stenede Sand paa Bakkerne og Morænegruset i Øens Østende har leveret rigeligt Stenmateriale.

Som overalt ved vore Kyster søger Strømmen ved Aflejring af Sand og Grus at gøre Kystlinien saa retliniet som mulig. Bugter og 
Vige fyldes efterhaanden med Sand, og Odder forlænges i Strømmens Retning, uden at denne Vækst af Landet dog er noget Tegn paa, at Landet hæves. Halvøen Fynsskov f. Eks. vokser stadig mod Nord, og samtidig ere de smaa Indskæringer langs Kysten udfyldte med marine Lag. Nord for Tønnæs Odde findes saaledes en temmelig bred Strandrold ud mod Stranden. Højden er 1,31,5 m., altsaa ikke større end at Søen med stærk Storm slaar op over den. Materialet er Sand og lidet rullede Sten af Størrelse som Nødder og Eg, sjældnere som en knyttet Haand. Man ser, hvorledes Strandvolden er vokset og endnu vokser Syd fra, og at dens Spids flere Gange er drejet Øst paa ind mod Land, hvorefter den atter er vokset videre mod Nord; den viser sig nu som en enkelt Vold langs Stranden, fra hvilken der bøjer en Række bueformede Ribber indad over Lavningen Øst derfor. Denne er udfyldt med Sand og i de inderste Partier med marint Dynd. Øst for Tønnæs Odde er Tønnæs Enghave ligeledes afdæmmet ved en lav, flad Strandvold bestaaende af Sand og kantet Grus. Endnu østligere, ved Sparretorn, var Halvøen tidligere kun et Hundrede Meter bred, men har nu ved de marine Aflejringer faaet en jævn og fortløbende Kystlinie.

De inderste Dele af de to Bugter Fyns Vig og Tybrind Vig ere i Tidens Løb sandede til. Det samme gælder det smalle Sund, der gik tværs over Landet Vest for Rud (L 3), og som forbandt Fyns Vig med Tybrind Vig. Sundet er nu udfyldt dels med Sand, dels med Dynd, og udenfor er opkastet smalle Strandvolde, der Nordøst for Aalehoved ligge som parallele Volde og vise Landets Tilvækst mod Nord. Lignende lave, smalle Strandvolde, der bestaa af Grus, findes paa Wedellsborg-Halvøen (L 2), dels ud mod Tybrind Vig, dels langs Sydkysten.

Paa Bogø findes Strandvolde næsten overalt, hvor Kysten er lav. Paa Øens Vestside kan man ved Vestermose iagttage, hvorledes Strandvolden paa Grund af Kystliniens Tilbagerykning vandrer indad over Tørven, saaledes at denne igen kommer til Syne i Stranden udenfor. Det samme findes paa Brandsø, hvor Mosen mod Nordvest strækker sig ud under Strandvolden og kommer frem under Sandet i Strandkanten. Paa Øens Sydvestside findes en veludviklet 1,8-1,9 m. høj Strandvold af smaagruset Sand.

Paa Thorø, Sydvest for Assens, findes ligeledes forholdsvis godt udviklede, 1,6-1,8 m. høje Strandvolde, der bestaa dels af Sand dels af Grus, og som fra Øens Nordside strække sig vifteformet ud mod Nordvest. Øst paa strækker der sig en lang, stadig voksende Odde ud mod den smalle, dybe Sejlrende mellem Thorø og den fynske Kyst.

Langs den jydske Kyst spille Stranddannelserne ligeledes en temmelig underordnet Rolle. Flade, lave Strandvolde findes som Regel 
foran Mundingen af Aaløbene og af de Dalstrøg, der naa ud til Kysten, samt ved enkelte Odder som f. Eks. Stendrup Hage og Indløbet til Hejlsminde. Inde i Mosvig findes et temmelig bredt Bælte af flade Strandvolde, der bestaa af smaastenet Sand.

Materialet til Strandvoldene stammer i Reglen fra tæet ved liggende Klinter med Moræneler eller andre stenholdige, glaciale Aflejringer. Paa Grund af den korte Vej, Stenene transporteres, og det som Regel svage Bølgeslag blive Stenene kun i ringe Grad rullede. Det er egentlig kun i Strandroldene paa Smaaøerne ude i Lillebelt, at man finder godt bearbejdet Strandgrus. Medens Gruset og de smaa Sten føres af Sted med Strømmen, blive de større Blokke liggende og - hvor de ikke tages af Stenfiskerne - yde de god Beskyttelse mod Nedbrydningen af Klinterne. Denne Nedbrydning er indenfor Kortbladsomraadet kun ringe, men dog paa mange Steder saa konstant, at Klinterne staa vegetationsløse og ofte med lodret Væg. Som Regel er Forstranden foran saadanne Klinter temmelig smal og som oftest dækket af opskyllet Tang (Fig. 5, Side 21 og Fig. 6, Side 25). Paa Thorøs Sydspids mangler Forstranden dog fuldstændig (se Fig. 4, Side 17); Moræneleret staar dér med lodret Klint direkte ned i Søen og er stadig udsat for Nedbrydning. Inde i Fjordene er Nedbrydningen meget ringe, Bølgeslaget ubetydeligt, og i de inderste Vige findes endog Sivbevoksning i det lave Vand langs Kysten.

Fjordaflejringer have ikke megen Betydning som Overfladedannelse. Som allerede bemærket er der ikke foregaaet nogen Landhævning, og hvad der derfor oprindelig aflejredes under Havets Orerflade, findes nu i samme eller i lavere Niveau. Kun hvor der ved Kunst er foretaget Udtørring af tidligere Fjordbund, har man Lejlighed til at studere disse Aflejringer.

Det største, fuldstændigt udtørrede Areal er Fynsvang (L 3), den inderste Del af Gamborg Fjord. Længden af det udtørrede Areal er $2300 \mathrm{~m}$., Bredden varierende fra 300 til $600 \mathrm{~m}$; det oprindelige Indløb var kun $150-200 \mathrm{~m}$. bredt og er nu lukket ved en Dæmning. Omgivelserne ere næsten udelukkende Moræneler. Selve den udtørrede Fjordbund, der ligger $1 / 2-1 \mathrm{~m}$. under Vandspejlet i Gamborg Fjord, bestaar i Midten af mørkt, sandet Dynd; langs Bredderne finder man over Dyndet et Bælte af Strandsand af vekslende Bredde og Mægtighed, og paa enkelte Steder baade langs Nord- og Sydkysten ses smaa Strandvolde af Grus.

For at bestemme Lagenes Mægtighed er der foretaget en Række Boringer langs Hovedkanalen, der fra Dæmningen og Slusen ved Gamborg Fjord løber mod ØSØ. gennem hele Fynsvang.

$200 \mathrm{~m}$. ØSØ. for Dæmningen laa Overfladen ved Kote $\div 0,4 \mathrm{~m}$. Der fandtes: 
fra $\div 0,4 \mathrm{~m}$. til $\div 1,7 \mathrm{~m}$. Strandsand med talrige Skaller.

- $\div 1,7$ - $\div 5,7$ - mørkt Cardiumdynd med færre Skaller.

- $\div 5,7-\quad \div$ ? Sand og smaastenet Grus.

Nogle Hundrede Meter længere mod ØSØ. fandtes Cardiumdynd lige fra Overfladen. Underlaget var her graat, fedt Moræneler.

$900 \mathrm{~m}$. ØSØ. for Dæmningen laa Overfladen ved Kote $\div 1,0 \mathrm{~m}$. Der fandtes:

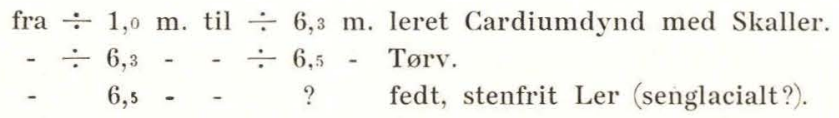

Denne dybtliggende Tørv kan herfra følges c. $1 \mathrm{~km} . \bmod \varnothing \mathbf{S} \varnothing$. som et $0,2-0,6 \mathrm{~m}$. mægtigt Lag mellem Cardiumdyndet og det stenfri Ler. Ind mod Sydøst i Fynsvangs inderste Del stiger Bunden og dermed Tørvelaget nærmere op mod Overfladen.

Ogsaa den i de marine Lag fundne Molluskfauna ${ }^{1}$ ) tyder paa en ægte Fjordaflejring. En Række Skalprøver, tagne fra den ydre til den indre Del af Fynsvang, vise overordentlig tydeligt, hvorledes Saltholdigheden er aftaget og dermed Faunaen bleven fattigere, jo længere man fjærner sig fra Fjordens Munding.

\section{Prøverne toges:}

a) i Sydvesthjørnet af Fynsvang, $400 \mathrm{~m}$. Syd for Mundingen, i Strandsand temmelig tæt ved den tidligere Kyst.

b) i Cardiumdynd, $1000 \mathrm{~m}$. fra Dæmningen, mellem Hovedkanalen og den nordlige Bred.

c) i Cardiumdynd, $1600 \mathrm{~m}$. fra Dæmningen, tæt ved Hovedkanalen.

d) i Cardiumdynd, $2000 \mathrm{~m}$. fra Dæmningen, noget Syd for Hovedkanalen.

Følgende Mollusker fandtes:

i a)

Ostrea edulis L. $81 \mathrm{~mm}$.

Mytilus edulis L.

Cardium edule L. $40 \mathrm{~mm}$.

- exiguum GMel.? 1 Ekspl.

Tapes aureus GMel. $32 \mathrm{~mm}$.

Scrobicularia piperata Gmel. $40 \mathrm{~mm}$. Macta subtruncata D. C. 2 Ekspl.

Tellina baltica L.

Mya arenaria L. $69 \mathrm{~mm}$.

Nassa reticulata L. $28 \mathrm{~mm}$.

Cerithium reticulatum D. C.

Rissoa membranacea AD.

Hydrobia ulva Penn.

Litorina litorea $\mathrm{L}$.

- rudis var. tenebrosa MTG.

Litorina obtusata L. 1 Ekspl.

Utriculus obtusus MTG.

Acera bullata MüLl. 1 Fragm.

1) Molluskskallerne i Saltvands-Alluviet ere bestemte af Mag. sc. V. Nordmann og Forfatteren. 
i b)

Ostrea edulis L. 1 Fragm.

Mytilus edulis L. sjælden.

Cardium edule L. $32 \mathrm{~mm}$.

Tapes aureus GMEL. $36 \mathrm{~mm}$.

Scrobicularia piperata GmeL.

Tellina baltica L.

Mya arenaria L. $60 \mathrm{~mm}$.

i c)

Mytilus edulis L. 1 Ekspl.

Cardium edule L.

Scrobicularia piperata GMeL. 1

Fragm.

Rissoa membranacea AD. alm.
Nassa reticulata L. $25 \mathrm{~mm}$.

Cerithium reticulatum D. C.

Rissoa membranacea AD.

- inconspicua ALdER. sjælden.

Hydrobia ulva Penn.

Litorina litorea $\mathrm{L}$.

- rudis var. tenebrosa MTG.

Rissoa inconspicua AldER. sjælden. Hydrobia ulva Penn. talrig.

Litorina litorea L.

- rudis var. tenebrosa MTG. Acera bullata MüLL. 1 Fragm.

i d)

Cardium edule L. $32 \mathrm{~mm}$. tyndskallet.

Hydrobia ulva Penn.

Litorina rudis var. tenebrosa MTG.

For ogsaa at undersøge Faunaens Variation i vertikal Retning blev der $200 \mathrm{~m}$. ØSØ. for Dæmningen foretaget en Gravning, der dog paa Grund af det stærkt tilstrømmende Vand ikke kunde føres mere end omtrent $1^{1 / 2} \mathrm{~m}$. ned under Jordoverfladen. Der toges her Prøver i forskellig Dybde, nemlig:

$$
\begin{aligned}
& \text { A fra } \div 0,40 \mathrm{~m} . \text { til } \div 0,75 \mathrm{~m} \\
& \mathrm{~B}-\div 0,75--\div 1,10- \\
& \text { C }-\div 1,10--\div 1,30- \\
& \text { D }-\div 1,30--\div 1,50- \\
& \text { E - } \div 1,50-\quad-\div 1,75-
\end{aligned}
$$

Prøverne A, B, C og D toges alle i Strandsand; Laget C naaede netop gennem Sandet og et lille Stykke ned i det underliggende Cardiumdynd (sml. den Side 74 anførte Boring fra samme Sted).

I omstaaende Tabel er anført de i disse Prøver fundne Mollusker. En $*$ angiver, at vedkommende Art fandtes i mindre end $10 \mathrm{Eksem}-$ plarer; et $X$ at den forekom i større Antal.

Det maa overraske, at Faunaen ikke er rigere, da man dog fra Lillebelt, der er et ret dybt Farvand med stærk Strøm og meget saltholdigt Vand, kender et betydeligt Antal Arter. Grunden er aabenbart den, at kun en ringe Del af det salte Vand naaer ind til det inderste af den lange og smalle Gamborg Fjord, og at desuden 
dennes inderste Del, Fynsvang, ved sin Munding kun har haft en Bredde paa næppe $200 \mathrm{~m}$.

Som det var at vente, er den i meget sen Tid indvandrede Mya arenaria almindelig i Strandsandets øverste Lag, i A, hvor den naaer en Længde af $70 \mathrm{~mm}$., men mangler i de derunder liggende, ældre Lag.

Af Ostrea edulis, der nu er fuldstændig forsvunden fra disse Farvande, fandtes kun faa Stykker, saavel voksne som Unger, og hyppigst i de øverste Lag.

\begin{tabular}{|c|c|c|c|c|c|}
\hline & $\mathrm{A}$ & $\mathrm{B}$ & $\mathrm{C}$ & $\mathrm{D}$ & $\mathrm{E}$ \\
\hline Ostrea edulis L. ............... & * & $*$ & * & . & $*$ \\
\hline Mytilus edulis L............... & X & $x$ & x & * & x \\
\hline Cardium edule L................. & $x$ & $x$ & x & $x$ & x \\
\hline - exiguum GMeL.......... & $*$ & * & X & $x$ & x \\
\hline Montacuta bidentata MTG. ......... & * & $*$ & * & $*$ & . \\
\hline Tapes aureus Gмen............... & X & X & x & X & $*$ \\
\hline Scrobicularia piperata GMEL.... ... & $x$ & $x$ & $x$ & $x$ & x \\
\hline Mactra subtruncata D. C......... & . & $*$ & $*$ & $*$ & . \\
\hline Tellina baltica L............... & $x$ & $x$ & * & $x$ & X \\
\hline - tenuis D. C........... & . & . & $x$ & $*$ & * \\
\hline Mya arenaria L................ & X & & . & . & \\
\hline Nassa reticulata L. .............. & $*$ & X & $x$ & $x$ & * \\
\hline Cerithium reticulatum D. C........ & $x$ & $x$ & x & $x$ & x \\
\hline Rissoa membranacea AD. ......... & x & $x$ & $x$ & $x$ & x \\
\hline - inconspicua Alder......... & * & $*$ & $x$ & $x$ & x \\
\hline Hydrobia ulva Penn. . . . . . . . . . . . & x & X & $x$ & $x$ & x \\
\hline Lacuna divaricata FABR. . . . . . . . . & . & * & . & . & . \\
\hline - pallidula D. C. .......... & . & $*$ & . & . & . \\
\hline Litorina litorea L. ............. & x & $x$ & $x$ & $*$ & $*$ \\
\hline - rudis MaT............. & . & . & $*$ & $*$ & $*$ \\
\hline - $\quad$ - var. tenebrosa МтG. . & $x$ & $x$ & X & $x$ & X \\
\hline - obtusata L. ............. & x & x & * & $*$ & . \\
\hline Utriculus truncatulus BRuG. ....... & $*$ & $*$ & $*$ & $*$ & * \\
\hline - obtusus Мта............. & X & $x$ & $*$ & . & . \\
\hline Acera bullata MǘL. ............. & $*$ & * & $x$ & $x$ & $x$ \\
\hline
\end{tabular}

Cardium edule var den talrigst forekommende Art. Den varierede i Størrelse fra $36 \mathrm{~mm}$. (i A) til $40 \mathrm{~mm}$. (i C).

Af Cardium exiguum fandtes saavel forholdsvis typiske Eksemplarer som den glatte Brakvandsform, der er kendt fra de indre Farvande og fra Østersøen. Den sidste Form findes dog ikke i Nutiden levende i det egentlige Lillebelt.

Tapes aureus var meget almindelig i de fire øverste Prøver; i E var den sjælden. Der fandtes saavel voksne som Unger. De største 
Eksemplarer naaede en Længde af $32-33 \mathrm{~mm}$. Arten er som bekendt nu uddød i Farvandene indenfor Skagen.

Tellina tenuis, der forekom baade som voksne Individer og som Unger, er i danske Aflejringer hidtil kun kendt fra Vendsyssel og er ny for de danske Øer. I Nutiden lever den sparsomt i Kattegat, gaar ikke ind i Belterne, og kun paa Grund af en Fejltagelse er den af Meyer og Møbius næunt fra Kielerbugt ${ }^{1}$ ). Sammen med Ostrea og Tapes viser denne Form, at de her undersøgte Lag i Fynsvang hidrøre fra Tapestiden.

Af Rissoa membranacea findes flere Varieteter, saavel ribbede som glatte.

Litorina litorea, der i de 3 øverste Prøver var meget almindelig og naaede en Størrelse af $28 \mathrm{~mm}$, blev temmelig sjælden i Prøverne D og E. Paa samme Maade aftog Litorina obtusata i Hyppighed nedad, hvorimod L. rudis var. tenebrosa var almindelig i alle Prøverne.

Medens Utriculus obtusus var almindelig i A og B og forsvandt i de dybere Lag, var det omvendte Tilfæeldet med $U$. truncatulus og i Særdeleshed med Acera bullata.

Nogen stor Variation i Vandets Saltholdighed, medens Lagene E til A aflejredes, har der næppe været. Dog er man vistnok berettiget til at betragte de Lag, hvori en Form som Tellina tenuis er almindelig, altsaa nærmest Laget $C$, som værende samtidige med Tapestidens og Tapesfaunaens Kulmination.

Endnu maa nævnes, at der i de marine Lag i Nordsiden af Fynsvang, tæt Sydvest for Ubby, er opgravet Dele af et Skelet af Pukkelhvalen, Megaptera boops ${ }^{2}$ ). Knoglerne findes nu paa Zoologisk Museum.

Samtidig med Tapeslagene ere de fra andre Egne i Landet saa velkendte Køkkenmøddinger fra den ældre Stenalder. Lignende Kulturlag findes ogsaa paa det her beskrerne Omraade, nemlig paa Øen Svinø i Gamborg Fjord. De ere fundne af Distriktslæge W. Dreyer og af ham kortelig omtalte ${ }^{3}$ ). Hr. Dreyer har desuden sendt Forfatteren følgende, mere udførlige Meddelelse om disse Kulturlag. Ved Øens Vestende findes et udbredt, men kun $1-3 \mathrm{dcm}$. tykt Lag, der bestaar af mørktfarvet Jord og Skaller, hovedsagelig af Mytilus edulis; desuden findes Litorina litorea, enkelte Ostrea edulis, Fragmenter af Tapes aureus o. fl., men ingen Oldsager. Laget ligger temmelig udsat og vaskes efterhaanden bort ved Højvande.

1) C. G. Joh. Petersen: De skalbærende Molluskers Udbredningsforhold i de danske Have indenfor Skagen. Kjøbenhavn 1888. Side 150.

$\left.{ }^{2}\right)$ H. Winge: Om jordfundne Pattedyr fra Danmark. Vid. Medd. naturh. Foren. for 1904. Kjøbenhavn 1905. Side 293.

$\left.{ }^{3}\right)$ W. Dreyer: Nordens Oldtid. Frem. Kjøbenhavn 1901. Side 12. 
Ligeledes paa Øens Vestende findes en mindre Plet med Trækul, Aske, en Mængde ildskørnet Flint og enkelte Skaller.

Paa Sydsiden findes et større Kulturlag med en Tykkelse af $1 / 2 \mathrm{~m}$. Det indeholder en stor Mængde Østersskaller og en Del Flintaffald. Lagets Karakter er en saadan, at det utvivlsomt stammer fra den ældre Stenalder. Blandt de fundne Molluskskaller kan nævnes Ostrea edulis, de fleste $60-70 \mathrm{~mm}$. i Diameter, enkelte vare større, indtil $95 \mathrm{~mm}$. lange, Mytilus edulis i store Fragmenter, Cardium edule, indtil $40 \mathrm{~mm}$. og 1 Ekspl. af Tapes aureus, $30 \mathrm{~mm}$. langt. Desuden Litorina litorea og Nassa reticulata.

\section{B. Ferskvandsaflejringer.}

Aflejringen af alluviale Ferskvandsdannelser, blandt andet af Tørv, er begyndt, saa snart de klimatiske Forhold vare blevne tilstrækkelig gunstige og er - paa det nuværende Landomraade - bleven fortsat indtil Nutiden. Men som nævnt Side 72 er der siden den alluviale Tids første Afsnit foregaaet en langsom og uafbrudt Landsænkning, hvorved store Arealer ere blevne dækkede af Havet. Tørvedannelsen paa disse Strækninger er da bleven afbrudt, til forskellig Tid, eftersom vedkommende Punkt laa højt eller lavt, og den allerede dannede Tørv vil nu kumne findes enten ude paa den nuværende Havbund eller dækket af marine Lag. Tørvelag fra dette ældre Afsnit af den alluviale Tid (Fastlandstiden, Ancylustiden) ere kendte fra talrige Steder langs Danmarks Kyster. Ogsaa indenfor Kortbladet Skamlingsbanke ere de efterviste, omend i langt ringere Grad end man skulde vente efter de tidligere og nuværende geografiske Forhold.

Kun fra et enkelt Sted kendes Tørvelag paa Havbunden, nemlig i Tybrind Vig ud for den 5-8 m. høje Morænelerklint Vest for Grevindeskov (L 2). Den submarine Mose ligger dog kun c. $25 \mathrm{~m}$. udenfor den nuværende Kystlinie.

Tørv dækket af marine Lag, og ældre end Tapestiden, er fundet ved flere af de Side 75 nævnte Boringer i Fynsvang. Tørvelaget, der kun havde en Mægtighed af $0,2-0,6 \mathrm{~m}$., fandtes $\mathrm{i}$ den indre Del af den tidligere Fjord og kunde følges ud ad til en Dybde af 6,5 m. under Havets Niveau.

Der er Sandsynlighed for, at man paa gunstige Steder vil kunne finde alluviale Tørvelag, i det mindste indtil saa stor en Dybde (c. $20 \mathrm{~m}$.), at Fyn ved en tilsvarende Hærning vilde blive landfast med den jydske Halvø.

Andre Tegn paa, at Landet har ligget højere, har man i de smalle, 
bugtede Render, hvormed enkelte af Fjordene og Aaløbene fortsætte sig ud over Havbunden. Smukt udviklet er dette ved Mundingen af Haderslev Fjord og omkring Øerne Orø og Linderum (Syd for Rigsgrænsen), hvor dybe Flodrender gennemskære Havbunden i forskellig Retning. Ogsaa Nord for Grænsen findes et karakteristisk Eksempel i Hejlsminde, hvor Kjærmølle Aa som en smal, bugtet Rende kan følges ud gennem det kun $1-1 \frac{1}{2}$ m. dybe Farvand til "Slusen“, hvorfra den, ligeledes som et smalt Flodløb, svinger tæt over mod den slesvigske Kyst, indtil den længere Øst paa taber sig ud mod det dybe Vand. I Hejlsminde skal der tidligere have været fersk Vand, men at den Forandring, der her er foregaaet, har sin Grund i en fortsat Landsænkning, er dog næppe sandsynligt ${ }^{1}$ ).

Paa den Del af Kortbladsomraadet, der nu er Land, er Aflejringen af Tørv og andre Ferskvandslag fortsat uden Afbrydelse, saaledes at Lag, der ere ældre end, samtidige med og yngre end Tapestiden, glide umærkeligt over i hverandre.

Alluvialt Ferskvandsgrus træffes yderst sjældent og som Regel kun i Bunden af de nuværende Aaer. Ferskvandssandet er mere almindeligt; det findes oftest i Aadalene og er for en stor Del nedskyllet fra Omgivelserne. I de fleste Tilfælde er det mørkt af indblandet organisk Stof; hvor Sandet er rent og lyst, lader det sig vanskeligt adskille fra det senglaciale Sand. Om det alluviale Ferskvandsler gælder det samme; det er i Reglen mørkt og dyndet, men har iøvrigt ikke stor Udbredelse. Langt almindeligere er Ferskvandsdyndet, der forekommer ikke alene langs Aaløbene, men ogsaa sammen med Tørven i de talrige Lavninger mellem Bakkerne. Nogen skarp Grænse kan der ikke trækkes mellem disse Aflejringer; der findes jævne Overgange fra Sand gennem Ler til Dynd.

1) Søren Abildgands Dagbog fra hans Rejser i Nordslesvig 1775-76, udgivet af M. Mackeprang. Sønderjydske Aarbøger 1906. Aabenraa 1906. Side 127-28. "Heils-Minde er en Viig eller Fjord, som holder brak Vand, men har fordum holdt sødt eller ferskt Vand og var da meget fiskeriig. I de Tiider var den smalle Aabning mellem Havet og Søen med Sluus Værk afsondret fra Belt-Søen, saaledes at Sluus-Portene lukkede sig, naar Havet reiste sig højere end Indsøens ferske Vand, men aabnede sig, naar Indsøen blev højere end Havet. Der var ved Sluusværket en Broe til almindelig Overfart, men alt dette blev med Tiden forfalden og ikke holdt i Stand, saa at Havet nu gaaer frit ind i Søen, hvorudover der nu ikke kan opholde sig fersk Vands Fiske, ikke heller HavFiske uden alene Aal og Reger, som her kaldes Purrer. Sluusværket skal efter gamle Folkes Sigende være bortskyllet for omtrent 80 Aars Tiid siden. Mundingen er omtrent 60 Skridt eller et Flinteskud bred, omtrent lige saa langt og har henved 15 Alen dybt Vand, men Indsøens Dybde er høist 3 a 4 Alen undtagen i Renden, hvor Strømmen af Aaen gaaer. Thi Aller Møllevand løber i denne Søe. 
Tørven, der har størst Betydning, er bedst udviklet i de større og mindre Lavninger, som Moræne-Terrainet er saa rigt paa.

Blandt større, eller i økonomisk Henseende værdifulde Tørvemoser kan nævnes f. Eks. Moserne Nordvest for Viby (L 3). De ere opstaaede i Lavninger i de senglaciale Aflejringer; den nordligste Mose, Kosmose, har en Dybde af c. 3 m. og hviler paa senglacialt Ler. I dette Ler fandtes den Side 60 omtalte Rensdyrtak.

Flere større Moser med betydelig Tørveskæring findes Øst for Ubby ud mod Kortbladgrænsen. En stor Del af den glaciale Flodrende Nord for Husby (L 2), hvor der nu ikke findes noget Vandløb af Betydning, er udfyldt med Tørv; i Sjoen har denne en Mægtighed af over $3 \mathrm{~m}$. og indeholdt $\mathrm{i}$ sin nederste Del en Mængde Skaller af Ferskvandsmollusker.

Paa Bogø spiller Tørven en stor Rolle som Overfladedannelse, men Mosernes Dybde er meget ringe, $1-1^{1 / 2} \mathrm{~m}$., og desuden er den Tørv og "Made" (en Mellemting mellem Tørv og Dynd), der findes, lidet anvendelig som Brændsel; saa godt som al den Tørv, der kan brændes, er allerede gravet bort. I Moserne findes Stammer af Eg og Birk.

Det er tidligere nævnt, hvorledes man baade paa Bogø og Brandsø kunde iagttage, at Strandvoldene efterhaanden vandrede ind over Moserne, saaledes at Tørven kom frem under Strandsandet paa Strandvoldenes ydre Side. Paa Brandsø indtager "Brandsø Mose" en stor Del af Øen. Det er en indtil $4 \mathrm{~m}$. dyb, lyngdækket Højmose, der i sin ørerste Del bestaar af Sphagnumtørv. I de dybere Lag findes en Del Birkekviste; baade i Dybden og mod Øst ind mod Øens Midte antager Tørven mere og mere Karakter af Kærmosetørv. I Særdeleshed mod Øst ses store Birke- og Egestammer, og i en enkelt Horizont i Tørven fandtes en Mængde Birkestubbe staaende paa Roden.

I Terrainet Vest for Lillebelt spiller Tørven en fuldt saa stor Rolle som paa den fynske Del af Kortbladsomraadet. Mod Nordøst indtager den et stort Areal langs Solkjær Aa mellem Stendrup og Kysten, men Tørven er her næsten ubrugelig som Brændsel og skæres ikke. Derimod foregaar der en betydelig Tørveskæring i Vindemose inden for Mosvig.

Syd og Vest for Skamlingsbanke findes flere større Moser. En Mose ved Sydenden af Bakkerne, Øst for Grundinghoved, ligger omgivet af stejle Skraaninger og har en Dybde af indtil $5 \mathrm{~m}$. I Tørven findes talrige, store Egestammer. Stor Dybde har Tørven ogsaa i den anselige Mose tæt Nordvest for Grundinghoved. Enkelte af Moserne ere endnu lyngdækkede, saaledes Gammelmose ved Sjølund; andre ere dækkede med et tyndt Sandlag og opdyrkede, som

Danmarks geologiske Undersøgelse. I. R. Nr. 12. 
f. Eks. Istak Mose Nord for Aastorp. I denne sidste fandtes 0,6 m. Sphagnumtørv, derunder mørk Tørv, i hvilken der stod en Mængde Egestubbe.

Mod Syd ved den slesvigske Grænse findes betydelige Mosedrag langs Kjærmølle Aa. Ogsaa Øst for Hejls ligger en større Mose med 2-3 m. Tørv, der hviler paa senglacialt Ler.

I Kortbladets vestligste Del ligge flere meget store Moser. Svanmose, Sydvest for Vonsild, er en lyngdækket Højmose, hvis øverste Del er ren Sphagnumtørv; den nedre Del af Tørven er Kærmosetørv med Grene og Stammer at Birk og Eg. Syd for Svanmose findes tæt ved Rigsgrænsen en Række meget store Moser, gennem hvilke Fovsaa nu løber. Her er en betydelig Tørveskæring; Tørven, der er indtil $4 \mathrm{~m}$. dyb, er for største Delen Kærmosetørv med talrige Stammer og Grene. Disse store Moser Vest for Haderslev-Landerej findes alle i flade Bassiner, hvis Dannelse rimeligvis er samtidig med Aflejringen af Endemorænen Vest derfor. De have - efter at Landisen var smeltet bort - været Søer, i hvilke senglacialt Ler, Sand og Grus er aflejret, og ere derefter i alluvial Tid blevne udfyldte med Tørv.

Af andre Ferskvandsaflejringer, der have Interesse, maa nævnes et Lag af Kildekalk umiddelbart Vest for Stendrup By (N 3), paa Skrænten ned mod Solkjær Aa. Laget, der har en Mægtighed af $0,6 \mathrm{~m}$., og som er dækket af Muld, findes ud for Grænsen mellem Diluvialsandet og det derunder liggende "nedre“ Moræneler (sml. Side 27), hvor Vandet vælder ud. I Kildekalken findes en Del Skaller af Land- og Ferskvandsmollusker.

Mere almindelig er den bløde Ferskvandskalk, der optræder som Lag i Moserne. Den er fundet f. Eks. i Mosen Øst for Hejls (N 2), hvor Laget havde den usædvanlige Mægtighed af $2 \mathrm{~m}$. og indeholdt mørke Striber af Gytje; endvidere Syd for Sjølund Skov og flere Steder.

\section{Flyvesand.}

Flyvesandet har i dette Terrain en meget ringe Udbredelse. Det findes f. Eks. paa Øerne Brandsø, Bogø og Thorø, men er saavel i geologisk som i praktisk Henseende uden nævneværdig Betydning. 


\section{Tillæg I.}

\section{Boringer og Brøndgravninger.}

I. Fabrik ved Norre Aaby Station. (L 3).

Terrainhøjde c. $22 \mathrm{~m}$. o. H. 1,7 m. Rødler.

1,9 - Mergel. Moræneler.

6,3 - Blaaler.

6,2 - Sand.

$16,1 \mathrm{~m}$.

II. Hus ved Norre Aaby Station. (L 3).

Terrainhøjde c. $22 \mathrm{~m}$. o. H. 1,7 m. Rødler.

1,9 - Mergel. Moræneler.

6,0 - Blaaler.

$9,6 \mathrm{~m}$.

III. Norre Aaby Mejeri. (L 3).

Terrainhøjde c. $22 \mathrm{~m}$. o. H.

$3,5 \mathrm{~m}$. Ler.

16,4 - Blaaler med Sten (Moræneler).

5.0 - Sand, stærkt vandførende.

1,5 - Blaaler.

Derunder skarpt, stærkt vandførende Sand.

$26,9 \mathrm{~m}$.
IV. Gaard i Brangstrup. (L 3).

Terrainhøjde c. $25 \mathrm{~m}$. o. H.

1,7 m. Rødler.

1,9 - Mergel. Moræneler.

6,9 - Blaaler.

Derunder vandførende Sand.

$10,5 \mathrm{~m}$.

V. Sparretorn. (L 3).

Terrainhøjde $4 \mathrm{~m}$. o. H.

$0,6 \mathrm{~m}$. Muld.

3,5 - Rødler og Mergel.

4,4 - Blaaler.

$8,5 \mathrm{~m}$.

VI. Dyrgaarden, Ubby. (L 3). Terrainhøjde $25 \mathrm{~m}$. о. H.

$1,7 \mathrm{~m}$. Rødler.

2,2 - Mergel. Moræneler.

14,4 - Blaaler. Derunder Sand.

$18,3 \mathrm{~m}$. 
VII. Tybrind. (L 2).

Terrainhøjde $13 \mathrm{~m}$. o. H.

$11,3 \mathrm{~m}$. gammel Brønd.

2,5 - fint Sand.

2,5 - stenfrit Ler.

5,0 - fint Sand.

0,6 - stenfrit Ler.

$10,7 \mathrm{~m}$. skarpere Sand.

Derunder et vandførende Lag af Smaasten.

$32,6 \mathrm{~m}$.

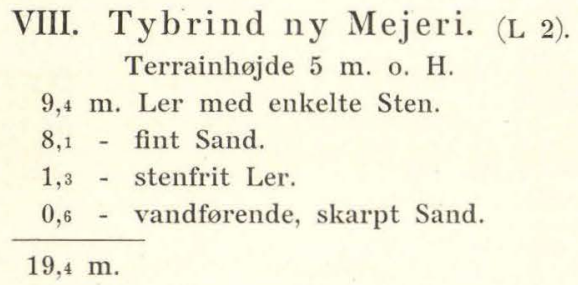

IX. Husby Skole. (L 2).

Terrainhøjde $25 \mathrm{~m}$. o. H.

$1,6 \mathrm{~m}$. Rødler.

1,9 - Mergel. Moræneler.

4,4 - Blaaler.

13,8 - skarpt Grus med store Sten. Derunder vandførende Grus.

$21,7 \mathrm{~m}$.

X. Husby Brugsforening. (L 2).

Terrainhøjde $15 \mathrm{~m}$. o. H.

$8,8 \mathrm{~m}$. stenet Ler.

9,4 - Grus, meget stenet.

3,8 - stenfrit Ler.

Derunder vandførende Sand.

$22,0 \mathrm{~m}$.

\section{Ny Gaard Ø. for Adler- hus. (L 2).}

Terrainhøjde $12 \mathrm{~m}$. о. H.

$11,9 \mathrm{~m}$. stenet Ler.

8,2 - stenfrit Ler.

5,0 - fint Sand.

Derunder vandførende, skarpt Sand.

$25,1 \mathrm{~m}$.
XII. Wedellsborg. (L 2).

Terrainhøjde $4 \mathrm{~m}$. o. $\mathrm{H}$.

$2,5 \mathrm{~m}$. Flydesand.

1,3 - Ler.

0,5 - sort "Dy-jord".

0,9 - Flydesand. I Lagets Underside fandtes forkullede Træstykker.

1,6 - gult Ler.

$1,4 \mathrm{~m}$. Flydesand.

4,4 - Blaaler med Sten (Moræneler).

12,9 - Flydesand. Fersk Vand steg til $2,5 \mathrm{~m}$. under Jordoverfladen.

16,9 - fedt Blaaler, meget sejgt og ildelugtende. I den øverste Del indeholdt det en Mængde smaa, halvforraadnede Snegle- og Muslingeskaller.

3,5 - Flydesand.

1,3 - Sten og Grus. Salt Vand steg til 2,2 m. under Jordoverfladen.

53,3 - Blaaler med vekslende haarde og bløde Lag. Leret var meget sejgt og faldt fra hinanden i Tærninger. Det var gulgraat $\mathrm{i}$ de øverste $5-6 \mathrm{~m}$., nedefter var det mørkere. Leret indeholdt haarde Mellemlag af en hvid Masse, samt røde Lag, der farvede Vandet højrødt.

7,9 m. haard, sort Skifer. Den blev slaaet i Stykker i Tærninger, der lignede Stenkul. Salt Vand steg til 2,2 m. under Jordoverfladen.

4,0 - Skifer eller Ler, lysegraat.

12,5 - haard Skifer med løse Mellemlag.

3,1 - haard Skifer. Salt Vand steg 7-8 m. over Jordoverfladen.

14,1 - Skifer med vekslende haarde og bløde Lag.

6,9 - Skifer, noget løsere.

4,7 - løs Kalk.

3,8 - Kalk med haarde Lag.

2,5 - løs Kalk.

5,0 - meget haard Kalk med Flint.

$165,0 \mathrm{~m}$.

XIII. Sjølund Mølle. (O 2).

Terrainhøjde $55 \mathrm{~m}$. o. H.

$0,3 \mathrm{~m}$. Muld.

6,3 - Mergel med Sten. 
$6,3 \mathrm{~m}$. Grus.

8,8 - Sand, ikke vandførende.

$21,7 \mathrm{~m}$.

XIV. Hejls Kro, (O 2).

Terrainhøjde $7 \mathrm{~m}$. o. $\mathrm{H}$.

17,3 m. Moræneler.

Derunder fandtes vandførende Diluvialsand, hvorfra Vandet steg højt over Jordoverfladen.

$17,3 \mathrm{~m}$.

XV. Ballegaard ved Hejls. Terrainhøjde $16 \mathrm{~m}$. o. H.

$1,3 \mathrm{~m}$. gult, kalkfrit Moræneler.

1,9 - gult, kalkholdigt Moræneler.

6,9 - graat,

Derunder vandforende Diluvialsand.

$10,1 \mathrm{~m}$.

XVI. Stavnsbjerg. (O 2).

Terrainhøjde 5, m. o. H.

$12,5 \mathrm{~m}$. Moræneler.

Derunder Diluvialsand.

$12,5 \mathrm{~m}$.

XVII. Eng Nord for Bygebjerg. (O 2).

Terrainhøjde $2 \mathrm{~m}$. o. H.

9,4 m. Moræneler.

10,4 - Diluvialsand.

1,6 - mørkt, stenfrit Diluvialler.

12,0 - Diluvialsand.

$33,4 \mathrm{~m}$.
XVIII. Kjær Mølle. (O 2).

Terrainhøjde $4 \mathrm{~m}$. o. H.

23,5 m. Moræneler.

Derunder Sand.

$23,5 \mathrm{~m}$.

XIX. Norgaard i Vonsild. (P 3).

Terrainhojde $44 \mathrm{~m}$. o. H.

$3,8 \mathrm{~m}$. gult Moræneler.

5,6 - graat Moræneler med faa store Sten.

$9,4 \mathrm{~m}$.

XX. Frederikshøj Kro. (P 2).

Terrainhøjde $39 \mathrm{~m}$. o. H.

$3,1 \mathrm{~m}$. Ler og Mergel.

15,6 - Grus.

15,7 - Mergel.

12,5 - vekslende Sand, haarde Sandlag og fint Grus.

3,1 - haardt Sand, ligesom løs Sandsten.

Derunder «Brunkul-Ler».

$50,0 \mathrm{~m}$.

XXI. Brendore Mølle. (P 2).

Terrainhøjde $60 \mathrm{~m}$. o. $\mathrm{H}$.

$6,6 \mathrm{~m}$. stenet Mergel.

6,3 - skarpt, stenet Sand.

6,9 - finere Sand, uden Vand.

$19.8 \mathrm{~m}$.

XXVII. Smedien ved Brendore Mølle. (P 2).

Terrainhøjde $60 \mathrm{~m}$. o. $\mathrm{H}$.

$6,9 \mathrm{~m}$. stenet Mergel.

7,8 - haardt Sand med Smaasten.

35,4 - fint, hvidt, tørt Sand uden Sten.

$50,1 \mathrm{~m}$.

Borejournalerne Nr. XII og XX findes i Mineralogisk Museums Arkiv. 


\section{Tillæg II.}

\section{Mekaniske Analyser af Jordarter.}

Af forskellige Jordarter: Moræneler, Diluvialler (dels typisk og stenfrit, dels den ejendommelige stenede Varietet), leret Diluvialsand og senglacialt Ler, er der foretaget mekaniske Analyser, hvis Resultater findes i omstaaende Tabeller. Et Par af Analyserne udførtes af cand. polyt. Alf. Stage, største Delen af cand. polyt. Poul HARDER.

Analyserne ere foretagne ved Hjælp af SchönE's Slæmmeapparat ${ }^{1}$ ) i Forbindelse med Orth's Hjælpetragt, efter den af P. Harder forbedrede Fremgangsmaade ${ }^{2}$ ).

Kulsyremængden i de samme Jordartsprøver bestemtes ved Hjælp af Scheibler's Apparat ${ }^{3}$ ); der er ved Beregningen af Procentmængden af kulsur Kalk ikke taget Hensyn til, at en ringe Del af Kulsyren er bunden til Magnesia.

1) F. Wahnschaffe: Anleitung zur wissenschaftlichen Bodenuntersuchung. Berlin 1903. Side 31 .

2) N. Steenberg og Poul Harder: Undersøgelser over nogle danske Sandsorters tekniske Anvendelighed. D. G. U., II R., Nr. 16. Kjøbenhavn 1905. S. $32-36$.

3) F. Wahnsghaffe: Anleitung zur wissenschaftlichen Bodenuntersuchung. Berlin 1903. S. 47. 


\section{Ikke-lagdelte Diluvialdannelser.}

\begin{tabular}{|c|c|c|c|c|c|c|c|c|c|c|c|c|}
\hline \multirow[b]{2}{*}{ Sted. } & \multirow{2}{*}{ 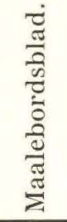 } & \multirow{2}{*}{\multicolumn{2}{|c|}{ Prøvens Art. }} & \multicolumn{8}{|c|}{ Kornstørrelse i Millimeter. } & \multirow{2}{*}{ 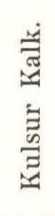 } \\
\hline & & & & $\begin{array}{l}\dot{\circ} \\
\wedge \\
\Lambda\end{array}$ & $\underset{i}{i}$ & 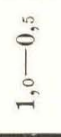 & $\begin{array}{l}0 \\
0 \\
0 \\
0 \\
0\end{array}$ & $\overrightarrow{0}$ & 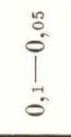 & $\begin{array}{l}\overrightarrow{0} \\
0 \\
0 \\
0 \\
0\end{array}$ & $\begin{array}{l}\overrightarrow{0} \\
\dot{0} \\
V\end{array}$ & \\
\hline & & & & $\%$ & $\%$ & $\%$ & $\%$ & $\%$ & $\%$ & $\%$ & $\%$ & $\%$ \\
\hline Klint SV. for Wedellsborg . .... & L 2 & Graat & - & 3,7 & 2,7 & 7,4 & 16,6 & 21,0 & 10,6 & 14,4 & 23,6 & 17,6 \\
\hline Klint N. for Fyret, Bogø....... & L 1 & - & - & 4,4 & 2,3 & 4,1 & 8,1 & 13,8 & 16,3 & 20,5 & 30,5 & 23,2 \\
\hline Tønnæs Odde, Fynsskov ........ & M 3 & - & - & 1,8 & 1,6 & 4,5 & 10,7 & 13,4 & 9,9 & 16,4 & 41,7 & 24,9 \\
\hline Klint ved Gammel Aalbo ....... & 一 & - & - & 1,3 & 1,0 & 3,3 & 7,7 & 9,8 & 7,6 & 14,2 & 55,1 & 27,6 \\
\hline Klint S. for Stendrup Hage ..... & - & - & - & 0,7 & 0,7 & 1,6 & 3,8 & 5,0 & 5,0 & 15,9 & 67,3 & 32,6 \\
\hline Klint ved Mosehus . ........... & N 3 & - & - & 1,0 & 1,0 & 3,0 & 7,4 & 10,2 & 9,9 & 13,1 & 54,4 & 24,8 \\
\hline do. & - & Gult & - & 2,6 & 1,8 & 6,0 & 13,0 & 17,0 & 10,2 & 13,7 & 35,7 & 17,4 \\
\hline Lergrav V. for Bindrup......... & O 3 & Brungult & - & 1,7 & 1,3 & 4,8 & 12,6 & 15,5 & 9,5 & 12,6 & 42,0 & 0,5 \\
\hline Sydenden af Skamlingsbanke.... & 一 & Gult & - & 3,1 & 2,3 & 8,1 & 17,5 & 16,9 & 8,9 & 9,2 & 34,0 & 18,4 \\
\hline Brøndgravning ved Hejls........ & $\mathrm{O} 2$ & Graat & - & 1,3 & 1,5 & 4,7 & 10,3 & 15,7 & 8,2 & 8,4 & 49,9 & 14,9 \\
\hline Vonsild $\ldots \ldots \ldots \ldots \ldots \ldots \ldots$ & P 3 & - & - & 2.1 & 1,6 & 4,6 & $10, y$ & 13,3 & 7,7 & 9,1 & 50,7 & 16,4 \\
\hline Nørgaard N. for Vonsild ........ & - & - & - & 2,1 & 2,0 & 5,6 & 12,2 & 17,1 & 7,0 & 8,1 & 45,9 & 14,8 \\
\hline
\end{tabular}


II. Lagdelte, diluviale og senglaciale Dannelser.

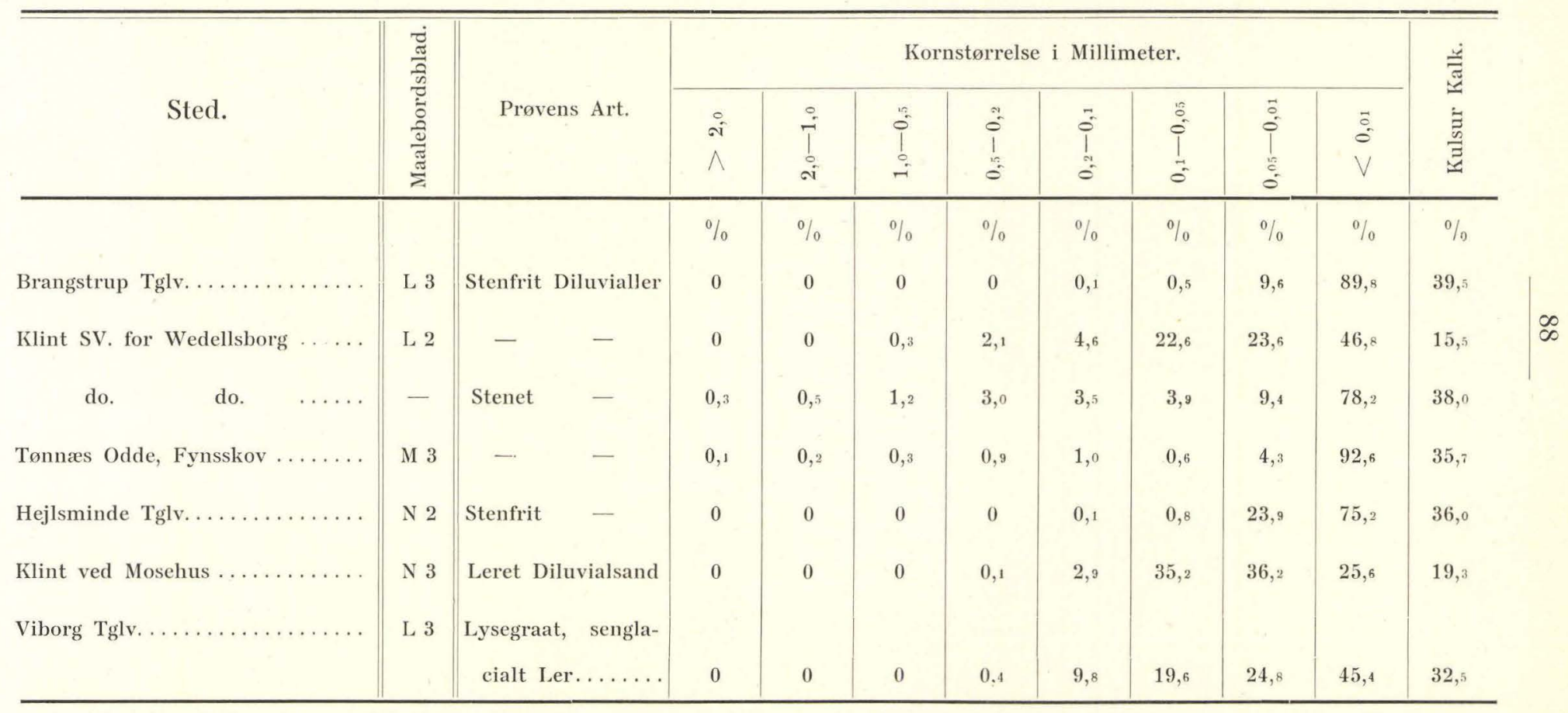




\section{Ré s u m é.}

Notice explicative de la feuille de Skamlingsbanke

(carte géologique du Danemark à l'échelle de 1:100,000). 
La feuille géologique intitulée Skamlingsbanke comprend une partie du pays situé des deux côtés du Petit Belt, soit en Fionie, soit dans le sud-est du Jutland. C'est un terrain morainique fertile et dont la surface est légèrement ondulée; à l'est du Petit Belt il semble qu'il y ait une certaine régularité dans l'étendue en longueur des chaînes de hauteurs; celle-ci va généralement du sud-est au nord-ouest ou de l'ESE. à l'ONO. Le même phénomène se manifeste par la forme de la côte, aux presqu'îles très prolongées, espacées par des fiords longs et étroits. Le type de ces presqu'îles étroites est celle de Fynsskov, avec son prolongement vers l'ESE par Fyns, Tybrind Skov et plus loin encore, au delà de la limite de la feuille. La hauteur des collines de cette contrée n'est pourtant pas considérable, le point le plus élevé ne se trouvant qu'à $53 \mathrm{~m}$. au-dessus de la mer.

Dans la partie jutlandaise du territoire, la surface ne présente pas la même régularité des formes; une seule croupe de colline, Skamlingsbanke (113 m.), immédiatement en dedans de l'anse Mosvig, domine les alentours (v. fig. 1, p. 3, et fig. $8-10$ pp. 65-67). Elle s'étend du NNE au SSO. Le pays tout autour est assez plat, en particulier dans la partie nord de la feuille; vers l'ouest et le sud-ouest, le terrain est plus accidenté, et les parties montueuses alternent ici avec des terres basses de grande étendue et des tourbières. Les hautes terres de la partie ouest de la feuille forment le point de partage des eaux entre la mer du Nord et le Petit Belt; en plusieurs endroits ce partage est cependant très peu accentué.

On trouve quantité de petits bois distribués sur toute la superficie de la feuille. Les cours d'eau sont de peu d'importance; par contre, quelquesunes des vallées bordant les rivières sont larges et étendues et, sans doute, d'origine glaciaire.

La partie du Petit Belt située dans les limites de la feuille, présente, vers le sud, un fond très uni et très plat; la profondeur en est, ici, de 15 à $25 \mathrm{~m}$. Vers le nord, où le Belt se rétrécit, la profondeur augmente. A la limite nord de la feuille, entre Stendrup Hage et Fynsskov, la profondeur en est de $50 \mathrm{~m}$. et peut même aller jusqu'à $80 \mathrm{~m}$. 


\section{Dépôts préquaternaires.}

(Aflejringer ældre end Kvartærformationen.)

Les dépôts des systèmes crétacé et tertiaire ne paraissent pas à la surface, mais on en a constaté l'existence par des sondages. A l'est du Petit Belt, la couche sous-jacente des dépôts glaciaires est formée par des dépôts tertiaires anciens; ainsi on trouva, près de Wedellsborg, 47,2 m. de dépôts diluviaux; là-dessous, 101,8 m. de dépôts tertiaires, et là-dessous encore, les dépôts du systéme crétacé (le danien). Les dépôts tertiaires se composèrent de $53,3 \mathrm{~m}$. d'argile plastique (oligocène inférieur?) et, la-dessous, 48,5 $\mathrm{m}$. d'argile de Kerteminde (paléocène). A l'ouest du Petit Belt, la couche sous-jacente des dépôts quaternaires est de l'argile micacée miocène. Souvent on trouve dans les dépôts glaciaires, des morceaux des couches sous-jacentes; c'est ainsi qu'on rencontre fréquemment des fragments d'une espèce de marne paléocène qui doit se trouver en couche fixe au-dessous du Petit Belt ou de l'ouest de la Fionie. Il arrive encore que l'on trouve dans l'argile morainique, des parties d'argile micacée, de sable micacé ou de gravier quartzeux tertiaires.

\section{Dépôts quaternaires.}

(Kvartærsystemets Aflejringer).

\section{Dépôts diluviaux (glaciaires).}

(Diluviale Aflejringer).

A. Dépôts glaciaires non stratifiés.

(Ikke lagdelte Diluvialaflejringer).

1. Argile et sable morainiques.

(Moræneler og Morænesand).

L'argile morainique forme la part prédominante de la surface. Cette argile est d'aspect ordinaire; pourtant sa composition est un peu variable: tantôt elle renferme beaucoup de sable, tantôt elle est très grasse et pauvre en galets. La composition physique de l'argile morainique ressort du tableau de la p. 87. Les parties supérieures sont fortement transformées par l'eau et par l'air (v. fig. 2, p. 11); jusqu'à 1 ou. 2 m. au-dessous de la surface, l'argile est généralement exempte de chaux et colorée jaune par le bioxyde de fer; là-dessous, on trouve souvent 1 à $2 \mathrm{~m}$. d'argile calcaire où, pourtant, les compositions de fer sont encore oxydées et prêtent à l'argile une couleur jaune, et ce n'est que là-dessous que l'on trouve, inaltérée, l'argile morainique grise, calcaire. La teneur en carbonate de chaux $\left(\mathrm{CaCO}_{3}\right)$ varie beaucoup; elle est, en moyenne, de 15 à $20 \mathrm{p}$. c.; dans l'argile morainique grasse elle monte jusqu'à 30 p. c., chiffre qu'elle ne dépasse que rarement.

La puissance de l'argile morainique varie passablement. A l'est du Petit'Belt elle est, vers le nord, de 8 à $10 \mathrm{~m}$. en moyenne; souvent elle est beaucoup moins considérable, et, sur de grandes étendues, l'argile morainique fait complètement défaut. Elle atteint sa plus grande 
puissance près de la station de chemin de fer de Nørre Aaby $(20 \mathrm{~m}$.) et à Ubby $(18 \mathrm{~m}$.). Vers le sud, la puissance varie de 2 à $12 \mathrm{~m}$., présentant une moyenne de 8 à $10 \mathrm{~m}$. A l'ouest du Petit Belt la puissance de l'argile est assez uniforme, de 6 à $8 \mathrm{~m}$., dans la partie nord-est de la feuille; elle peut s'élever, cependant, à $12 \mathrm{~m}$. et au-delà. Vers le nordouest, la puissance varie davantage; mais pour cette contrée il est impossible d'en indiquer le maximum. Dans l'amas de collines autour de Skamlingsbanke l'argile morainique est d'une puissance très variable, et elle s'élève, d'une figuration irrégulière, échancrée, au-dessus du sable fluvioglaciaire. Au sud de Skamlingsbanke la puissance va fortement croissante, et dans le bas terrain à proximité de la frontière du royaume elle dépasse généralement $10 \mathrm{~m}$. (à Hejls, de 13 à $17 \mathrm{~m}$.; près de Kjær Mølle, même 23,5 m.) Dans la partie ouest de la feuille il y a de grandes étendues où l'argile morainique fait complètement défaut, de sorte que les dépôts glaciaires antérieurs apparaissent à la surface. En d'autres endroits l'argile se présente en une couche mince, de 1 à $2 \mathrm{~m}$., et enfin il y a des endroits où la puissance en est de 6 à $8 \mathrm{~m}$. et au-delà.

Les conditions de gisement sont extrèmement uniformes; partout où l'on a pu étudier les couches sous-jacentes de l'argile morainique, elles se sont composées de dépôts glaciaires stratifiés, argile, sable ou gravier. On trouve communément des profils présentant de l'argile morainique au-dessus de sable glaciaire stratifié. A la côte occidentale de l'île de Thorø p. ex., on trouve un bon profil où, sur une longue étendue, on peut remarquer la limite presque horizontale entre l'argile morainique et le sable glaciaire (v. fig. 3, p. 15). Dans la partie sud de cette même falaise le profil tout entier présente de l'argile morainique, et la plage se réduit à rien, l'argile s'enfonçant à pic dans la mer (v. fig. 4, p. 17).

Dans plusieurs des falaises à l'est du Petit Belt il arrive que l'on trouve, renfermé dans l'argile morainique, un dépôt d'argile glaciaire d'une puissance d'un à deux m.; il se présente comme une bande ondulée, souvent sur un long parcours. C'est là le cas p. ex. au sud-ouest de Wedellsborg (v. fig. 6 et 7, p. 25), où la série des dépôts est la suivante: en haut, de l'argile morainique; là-dessous, par rang d'ordre, de l'argile glaciaire stratifiée, de l'argile morainique, de la brèche et, enfin, du sable glaciaire. Le dépôt d'argile glaciaire renfermé dans l'argile morainique, est tantôt typique et exempt de galets, tantôt il renferme des galets, et alors souvent en quantité considérable. Il est à supposer qu'il y ait lá une formation subglaciaire faisant partie de la moraine de fond.

L'argile morainique est souvent disposée en bancs, et cette disposition se retrouve le plus fréquemment là où l'argile morainique a incorporé beaucoup de sable et de gravier de la couche sous-jacente. Dans le sable morainique, qui n'est que faiblement répandu comme formation de surface, la disposition en bancs est extrèmement commune.

Plusieurs dépôts d'argile morainique séparés par des dépôts fluvioglaciaires plus puissants, voilà un phénomène reconnu soit par des sondages (XII, p. 84, et XX, p. 85), soit dans quelques unes des profondes vallées à l'ouest du Petit Belt, comme p. ex. près de Stendrup et de Vonsild. Ou trouve ici, sur le plateau, de l'argile morainique, qui descend la pente jusqu' á une certaine hauteur; là-dessous, on rencontre des dépôts fluvioglaciaires, sable, gravier, ou argile sans galets; en bas, de 
l'argile morainique de nouveau. A la limite entre les dépôts fluvioglaciaires et l'argile morainique d'en bas se trouvent des sources nombreuses. On n'a pu déterminer si ces deux horizons d'argile morainique correspondent à deux périodes glaciaires ou seulement aux oscillations de la glace continentale.

Pour arriver à une comparaison de l'argile morainique des différents endroits on a procéde à une série d'énumérations de blocs (v. le tableau des pp. 29 à 31). De chaque endroit on a pris $10 \mathrm{~kg}$. d'argile morainique, les blocs en ont été isolés par lavage, et on a soumis à l'énumération tous les blocs au-dessus de $6 \mathrm{~mm}$. et moins gros qu'un œuf de poule. La proportion entre le pour-cent du silex et celui des blocs éruptifs, proportion ordinairement bien constante pour l'argile morainique d'une même couche, ne semble pourtant pas, pour cette contrée, pouvoir justifier des conclusions ultérieures, étant donné que cette proportion est fortement variable (de 0,5 à 3,0 ) et ne semble avoir aucun rapport avec la situation de l'argile, ni avec la profondeur à laquelle celle-ci se trouve au-dessous de la surface.

\section{Gravier morainique et sable à galets.}

(Morænegrus og Stenet Sand.)

On ne trouve que rarement, et seulement sur de petites étendues (Svinø, Grundinghoved, Ødis), du gravier morainique à l'aspect typique: une masse compacte de blocs anguleux, striés par la glace, entre lesquels se trouve du gravier argileux ou de l'argile morainique. Parfois on rencontre dans le gravier morainique des bandes et des dépôts peu importants de sable et de gravier fluvioglaciaires.

En plusieurs endroits, et surtout dans la partie ouest de la feuille, la surface se trouve parsemée de gros blocs, phénomène qui, sans doute, a dû être beaucoup plus ordinaire autrefois.

Par contre, le sable à galets se trouve encore très répandu, recouvrant, en une couche d'un m. à $1 \mathrm{~m}$. $1 / 2$ d'épaisseur, des étendues considérables de sable glaciaire stratifié ou d'argile morainique. Cette couche ne démontre pas de stratification ni de triage; des blocs de toutes dimensions se trouvent pêle-mêle dans le sable, imprimant à celui-ci un caractère morainique. En raison de la nature des blocs (on n'y trouve pas de roches molles, mais exclusivement des gangues dures, non friables; et quelquefois, même bien au-dessous de la surface, les blocs sont usés par les sables mouvants), il est à supposer que le sable à galets provienne de la moraine intérieure et de la moraine de surface de la glace continentale, et que, lors de la fonte de la glace, il ait été déposé en une couche mince au-dessus des dépôts plus anciens.

\section{Les blocs erratiques.}

(De lose Blokke.)

Parmi les minéraux cristallins, ceux de la Baltique représentent la grande majorité; cependant on a trouvé aussi, un peu partout dans le territoire de la feuille, bon nombre de blocs norvégiens, avant tout du porphyre rhomboïdal des environs du fiord de Christiania; de ce dernier minéral il a été trouve 70 à 80 morceaux. En fait de roches baltiques, on trouve très communément du granit et du porphyre d'Åland; c'est encore le cas pour le porphyre de Dalécarlie et pour celui du fond de 
la Baltique au sud d’Åland. Le granit et le porphyre de Småland et le basalte de Scanie sont plus rares à trouver.

Les blocs sédimentaires, à fossiles, ont éte examinés par K. A. Grønwall. La plus grande part de ces blocs témoignent également d'un transport du bassin de la Baltique. En fait de blocs du silurien inférieur on trouve ainsi de la chaux à Ortocer d'Øland, de même que de la chaux de Wesenberg et de la chaux à Paléoporella de la Baltique. Du silurien supérieur on trouve de la chaux à Beyrichia de l'île d'Øsel et de la Scanie, ainsi que du grès de la Scanie. L'une des roches à Cyrena aura été probablement transportée ici du nord; une couple de blocs du jurassien supérieur sont sans doute originaires de la Baltique, et un très grand bloc de Kelloway contenant de nombreux fossiles, tire son origine d'encore plus loin vers l'est, probablement des provinces baltiques russes. Un bloc de grès calcaire du Sénonien inférieur provient sans doute de la Baltique au nord de la Prusse. Les blocs crétacés et tertiaires sont à considérer, pour la plus grande part, comme étant de provenance locale; on pourrait nommer, entre autres, plusieurs blocs de calcaire de Faxe et les blocs assez communs d'une marne siliceuse paléocène. Il y a abondance de silex et de calcaire du danien et du sénonien supérieur. Presque tous les blocs à fossiles ont été ramassés sous la falaise d'argile morainique au Nord de Vargaarde, du côté ouest du Petit Belt (v. fig. 5, p. 21).

En face de Hejlsminde on a trouvé, dans l'eau, entre les galets de la côte, une molaire d'Eléphas primigenius. De plus, on a trouvé, tant dans les dépôts morainiques que dans le gravier fluvioglaciaire, bon nombre de fragments de coquilles (v. le tableau de la p. 46), parmi lesquelles Cyprina islandica apparaît le plus communément. Un fait intéressant est encore l'apparition de fragments de Tapes aureus GMel. var., apparition connue du diluvium marin du sud du bassin de la Baltique.

\section{B. Dépôts glaciaires stratifiés.}

(Lagdelte Diluvialaflejringer).

Un diluvium à fossiles semble avoir été trouvé par un sondage près de Wedellsborg, où l'on a trouvé, à $25 \mathrm{~m}$. au-dessous de la surface, une couche, de $17 \mathrm{~m}$. de puissance, d'argile grasse contenant des coquilles de limaçon et de moule. Il est possible que cette argile corresponde à l'argile à Cyprina au sud de la Fionie.

\section{Argile diluvienne stratifiée. (Lagdelt Diluvialler).}

L'argile diluvienne se présente le plus souvent comme couches secondaires parmi le sable diluvien; comme formation de surface elle ne joue qu'un rôle très restreint. Elle présente sa plus grande étendue à l'ouest du Petit Belt, immédiatement au nord de Hejlsminde; sur une superficie, longue de $2 \mathrm{~km}$. et large de la moitié, la couche d'argile morainique fait défaut, de sorte que le sable et l'argile stratifiés se présentent au jour. Les couches se rangent de la manière suivante: d'abord, par endroits, de l'argile morainique; là-dessous, de 2 à $5 \mathrm{~m}$. de sable diluvien; là-dessous encore, jusqu'à $5 \mathrm{~m}$. d'argile diluvienne, exploitée dans plusieurs briqueteries; et, tout en bas, du sable diluvien, dont on ne connaît pas la puissance. L'argile se présente soit en strates régulières, soit broyée en petits morceaux à arêtes vives. On la voit au fond des vallées ainsi qu'aux falaises le long 
de la côte. A l'est du Petit Belt, l'argile diluvienne se rencontre, comme déja nommé, en différents endroits dans l'argile morainique, comme couches d'une puissance d'un à deux $\mathrm{m}$. (v. fig. 6 et $7, \mathrm{p} .25$ ).

La texture de l'argile diluvienne ressort des analyses portées au tableau de la p. 88. La teneur en carbonate de chaux $\left(\mathrm{Ca} \mathrm{CO}_{3}\right)$ varie de 15 à 40 p. c.

\section{Sable diluvien stratifié.}

(Lagdelt Diluvialsand).

Le sable diluvien forme presque partout la couche sous-jacente de l'argile morainique, outre qu'il paraît à la surface en beaucoup d'endroits. Il a donc une grande extension, et il est de première importance pour le drainage des terres et pour le mouvement de l'eau souterraine.

Les conditions de gisement sont le plus souvent identiques et d'une assez grande régularité. La couche sous-jacente du sable diluvien n'est connue qu'en peu d'endroits; le sable repose soit sur de l'argile morainique antérieure, soit sur des couches tertiaires. Il est couvert par des dépôts morainiques, tantôt la moraine de fond, tantôt la moraine de la fonte des glaces (sable à galets). Tantôt les couches en sont pliées, tantôt dressées debout, mais le plus souvent elles sont horizontales, même là où elles sont couvertes par la moraine de fond (v. fig. 3, p. 15) ou que la surface est très accidentée. La croupe sablonneuse élevée et bien marquée, qui fait suite à la presqu'île Fynsskov en s'étendant vers le sud-est jusqu'à la limite est de la feuille, se compose ainsi de sable diluvien assez fin d'une stratification intacte et presque horizontale. Dans l'amas de collines autour de Skamlingsbanke, en dedans de l'anse Mosvig, on trouve des couches de sable tant horizontales que pliées et inclinées. Dans la partie montueuse du côté sud-ouest de la feuille, les conditions de gisement sont le plus souvent irrégulières.

Le sable diluvien renferme généralement de minces couches de gravier. Dans certains cas on trouve aussi des couches de débris végetaux, mais ceux-ci-que l'on trouve en lit secondaire-sont tellement décomposés qu'il est impossible de les déterminer exactement. Ils se présentent le plus souvent comme stries noires dans le sable (v. fig. 3, p. 15).

La teneur en chaux du sable diluvien ainsi que la grosseur du grain sont très variables. La teneur en chaux se manifeste souvent par la présence d'un grand nombre de bryozoaires de craie.

\section{Gravier diluvien stratifié.}

(Lagdelt Diluvialgrus).

Le gravier diluvien se rencontre presque toujours joint au sable diluvien et présentant des conditions de gisement absolument identiques à celui-ci. Il est pourtant assez rare, et c'est seulement en des localités étroitement circonscrites, que le gravier se présente dans le sable en de telles quantités qu'il en arrive a avoir une importance pratique. C'est dans la partie sud-ouest de la feuille que le gravier diluvien est le plus répandu; sa puissance atteint ici jusqu' à 8 ou $9 \mathrm{~m}$.; à Frederikshøj Kro elle s'élève même à plus de $15 \mathrm{~m}$. (v. sondage $\mathrm{XX}, \mathrm{p}$. 85). Le plus souvent la stratification est horizontale; dans certains cas on la trouve pourtant très dérangée sous l'influence de la glace continentale. 
Les blocs caractéristiques, de même que les fragments de coquilles de mollusques, contenus dans le gravier diluvien, se trouvent mentionnés aux pp. 35-46, et p. 94 .

\section{Dépôts glaciaires postérieurs.}

(Senglaciale Aflejringer).

L'argile glaciaire postérieure d'eau douce forme assez souvent, avec du sable, la matière qui remplit de légères dépressions dans le terrain morainique. Cette argile est toujours très régulièrement stratifiée, et elle n'est recouverte que de dépôts alluviaux. Elle renferme quelquefois des coquilles de mollusques d'eau douce et des débris de plantes arctiques, telles que Betula nana et Salix reticulata. Dans le marais de Kosmose, au nord-ouest de la station de Nørre-Aaby, on a trouvé, dans l'argile glaciaire postérieure, au-dessous de la tourbe, une branche d'un bois de renne, Rangifer tarandus.

Le sable et le gravier glaciaires postérieurs se trouvent souvent dans les larges vallées d'origine glaciaire et dont la coupe transversale présente la configuration d'un U. Le sable s'est laissé charrier ici par l'eau, et il a aplani le fond des rigoles que l'eau de fonte de la glace continentale a creusées dans le terrain devant le bord de la glace. Dans la partie ouest de la feuille, le gravier glaciaire postérieur apparaît en plusieurs endroits comme de petits cordons littoraux le long du bord des plis de terrain actuellement remplis de tourbe, mais qui ont existé comme lacs peu profonds immédiatement après la fonte de la glace.

Les blocs erratiques dénotent que la glace continentale a dû s'avancer par la dépression baltique et même, en partie, par le côté sud-est de celle-ci; elle a donc dû, ensuite, tourner vers l'ouest ou l'ONO pour arriver, par le Petit Belt, au terrain dont on vient de faire la description. En comparant l'extension des dépôts glaciaires postérieurs aux dépôts morainiques et les formes de terrain qui s'y rapportent, il sera possible d'indiquer certaines lignes démarquant les limites où le bord de la glace a dû rester stationnaire assez longtemps pendant la fonte de la glace continentale. Dans la partie ouest de la feuille, le bord de la glace semble avoir eu presque la direction du nord au sud, tandis que, plus tard, à l'est du Petit Belt, il a été probablement dirigé du NNE au SSO.

A la limite ouest de la feuille et, en partie, encore plus loin vers l'ouest, il se trouve une moraine terminale, large et plate, devant laquelle (toujours plus loin vers l'ouest) il y a de grandes plaines de sable. A Ødis, cette moraine coupe la limite de la feuille, après quoi elle se continue vers le sud-ouest sous forme de moraines marginales recourbées. A l'est de là se trouve un terrain bas, occupé maintenant par de grandes tourbières. La seconde ligne marginale de la glace s'ètend à partir de Vonsild, vers le SSO, jusqu'à Kransbjerg Gaard; elle est caractérisée par un terrain morainique très inégal, à petits sommets. Juste près de Vonsild, la vallée entourant la rivière de Sest Aa, d'une rigole sans impor-

Danmarks geologiske Undersøgelse. I. R. Nr. 12. 
tance qu'elle était, se change en une large vallée au fond plat et aux coteaux escarpés, lit de torrent indubitablement glaciaire, ayant son cours vers le nord-ouest et déchargeant les eaux de fonte du bord de la glace dans le fiord de Kolding. Encore plus à l'est on trouve probablement une ligne marginale de la glace, le long de Solkjær Aa depuis Damkjær Gaard jusqu'à Ajtrup. A partir de cet endroit, un grand torrent d'eau de fonte s'est creusé un lit large et profond à travers le terrain élevé, se dirigeant vers le nord-ouest en passant près de Skartved; dans cette vallée il n'y a pas, aujourd'hui, de cours d'eau. Enfin on trouve, en dedans de l'anse Mosvig, une ligne marginale de la glace à la croupe de colline élevée près de Skamlingsbanke; cette ligne est courte, mais très prononcée. Vers l'ouest, la côte est assez escarpée (v. fig. 8, p. 65); à l'est de la croupe, on trouve un terrain morainique accidenté (v. fig. 9 et 10, p. 67). Tandis que la croupe se compose essentiellement de matières fluvioglaciaires et n'est recouverte qu'en partie, d'un léger manteau d'argile morainique, l'argile morainique prédomine dans le terrain ondulé à l'est de la croupe.

A l'est du Petit Belt on ne trouve pas de lignes bien marquées pour indiquer le bord de la glace, mais la forme des presqu'îles et des collines dénote que le mouvement de la glace a été dirigé de l'ESE à l'ONO. La croupe sablonneuse élevée, entre Fyns et Tybrind Skov, a été probablement formée par un torrent d'eau de fonte se déchargeant au bord de la glace, à mesure que ce bord s'est retiré vers le sud-est.

\section{Dépôts alluviaux.}

(Alluviale Aflejringer).

\section{A. Dépôts marins.}

(Saltvands-Aflejringer).

A la fin de la période glaciaire et pendant la période à Ancylus, la contrée comprise dans notre feuille était beaucoup plus élevée que maintenant; depuis lors elle s'est affaissée continuellement, tant durant la période à Tapes (Litorina) que dans la période suivante. En conséquence, les dépôts marins n'ont que très peu d'extension; ils se sont, pour la plus grande part, encore affaissés après avoir été déposés. On les étudie le mieux là où ils ont été mis à sec artificiellement, comme p. ex. à Fynsvang, partie intérieure, maintenant desséchée, de Gamborg Fjord. Les dépôts marins, composés, le plus souvent, d'argile et de vase, atteignent ici une puissance de 5 à $6 \mathrm{~m}$., ayant pour couche sous-jacente tantôt des dépôts glaciaires, tantôt de la tourbe de la période à Ancylus. Aux pp. 75 et 76 se trouve citée la faune trouvée dans l'argile, les points $\mathrm{a}, \mathrm{b}, \mathrm{c}$ et d étant situés à des distances respectives de 400, 1000, 1600 et $2000 \mathrm{~m}$. de la digue séparant Fynsvang de Gamborg Fjord. Le tableau de la p. 77 indique la variation de la faune (trouvée au point b) en sens vertical, de $\div 0,4 \mathrm{~m}$. (A) à $\div 1,75 \mathrm{~m}$. (E). Le signe $X$ au tableau indique que l'espèce est commune, le signe *, qu'elle s'est trouvée en un nombre de moins de 10 exemplaires. L'apparition de Mya arenaria dans la couche supérieure dénote que cette couche est, en partie, de date très récente. Du nombre des autres espèces on ne retrouve plus dans ces parages ni Ostrea edulis, ni Tapes aureus, ni Tellina tenuis. Les couches $\mathrm{B}, \mathrm{C}, \mathrm{D}$ et en partie aussi $\mathrm{E}$, tirent donc indubitablement leur origine de 
la période à Tapes. Dans les dépôts marins à Fynsvang on a trouvé, en outre, des fragments d'un squelette de la jubarte, Megaptera boops.

Plusieurs Kjœkkenmoddings de l'âge de la pierre, trouvés du côté sud-ouest de Svinø, sont du même âge que la faune à Tapes.

\section{B. Dépôts d'eau douce.}

\section{(Ferskvands-Aflejringer).}

Parmi ceux-ci, la tourbe est la plus importante, au point de vue technique comme au point de vue géologique. On a déjà nommé la tourbe originaire de la période à Ancylus, située au-dessous des couches à Tapes à Fynsvang. Des couches de tourbe correspondantes se trouvent au fond de l'eau à Tybring Vig; et les lits de fleuve submarins à Hejlsminde et à l'embouchure de Haderslev Fjord témoignent du niveau plus élevé des terres dans la période à Ancylus.

On trouve les tourbières éparses sur tout le terrain, tantôt sous forme de petits marais forestiers, tantôt comme marais de grande étendue, partiellement couverts de bruyère, et dont les parties inférieures se composent de tourbe de marais vert contenant des troncs de chêne et de bouleau, tandis que les couches supérieures sont formées de tourbe à Sphagnum.

\section{Sables mouvants. \\ (Flyvesand).}

On trouve des sables mouvants en très faible quantité dans les îles du Petit Belt, et ils sont absolument sans importance. 
Danmarks geologiske Undersögelse. 1.Række Nr. 12.

SKAMLINGS BANKE
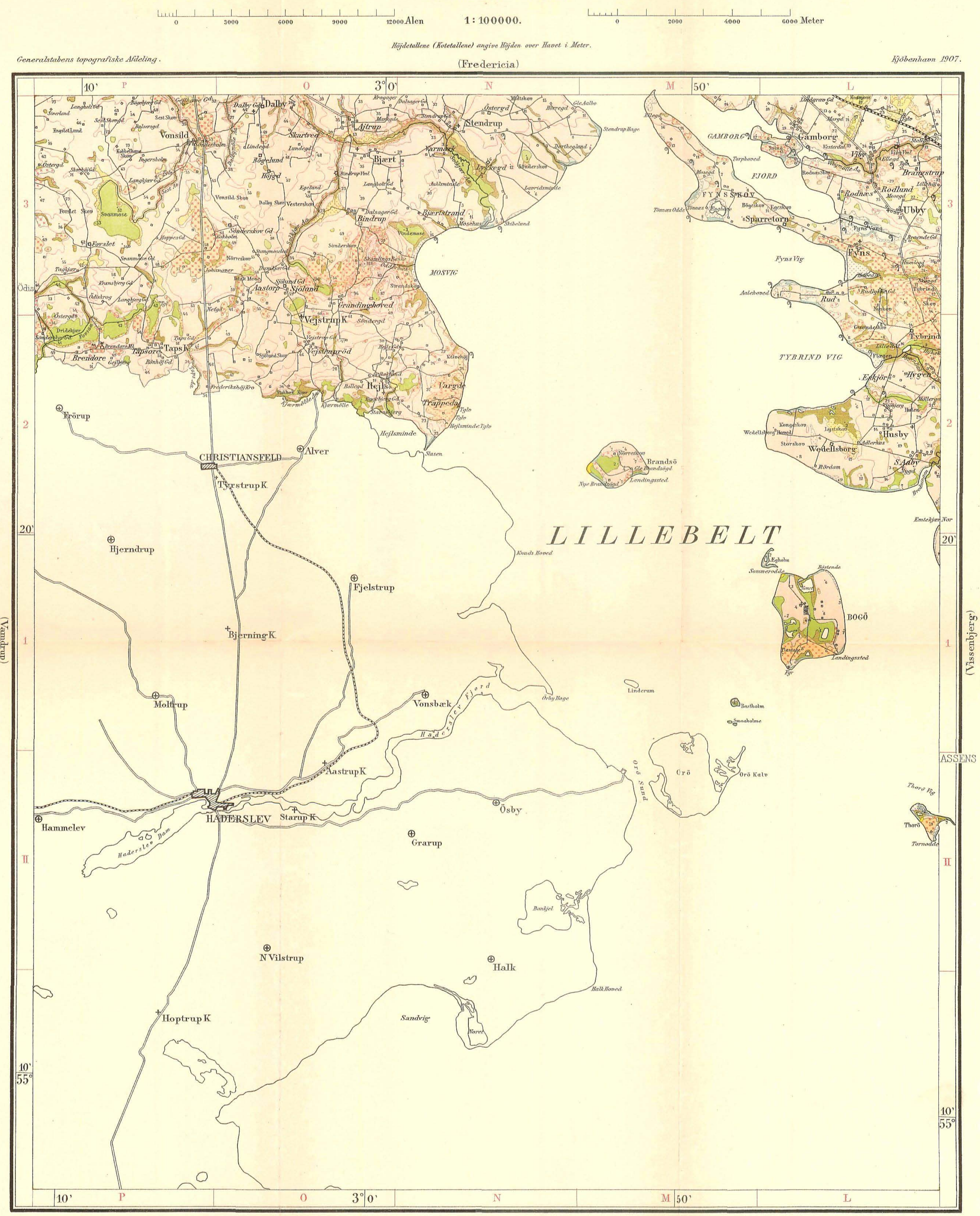

Postglaciale Dannelser (Alluvium)
Flypesand 
Nr. 2. K. Rørdam. Saltvandsalluviet i det nordostlige Sjæland. $1892 \ldots \ldots \ldots \ldots \ldots \ldots \ldots$. . . . . . . 3, . $00 \mathrm{Kr}$.

- 3. K. Rørdam. Geologisk-agronomiske Undersøgelser ved Lyngby Landboskole og Brede Ladegaard. $1894 \ldots \ldots \ldots \ldots \ldots \ldots \ldots \ldots$

- 4. Henr. J. Posselt. Brachiopoderne i den danske Kridtformation. $1894 \ldots \ldots \ldots \ldots \ldots \ldots \ldots$ - 1,25 -

- 5. K. Rørdaм. Beretning om en geologisk Undersøgelse paa Frænnemark ved Svaneke paa Bornholm. 1895 . . . . . . . . . . . .

- 6. K. Røвdaм. Kridtformationen i Sjæland i Terrænet mellem Kjøbenhavn og Kjøge, og paa Saltholm. 1897 .

Rørdam og C. Bartholin. Om Forekomsten Dễnmark. 1898 .
af Juraforsteninger i løse Blokke i Moræne- ler ved Kjøbenhavn. $1897 \ldots \ldots \ldots \ldots \ldots$.
- 8. Ethel G. Skeat and Victor Madsen. On Jurassic, Neocomian and Gault boulders found in

- 9. N. Hartz og E. Østrup. Danske Diatoméjord-
Aflejringer og deres Diatoméer. $1899 \ldots \ldots$ - 1,25 -

- 9. N. Hartz og E. Østrup. Danske Diatoméjord-
Aflejringer og deres Diatoméer. $1899 \ldots \ldots-1,25$ -

- 10. Bidrag til Bornholms Geologi I. - K. A. GrönWALL: Bemærkninger om Bornholms sedimentære Dannelser og deres tektoniske Forhold. J.P. J. Ravn: Trilobitfaunaen i den bornholmske Trinucleusskifer. A. Нлогтн: Om Vellengsbyleret og dets Flora. N. V. Ussing: Sandstengange i Granit paa Bornholm. 1899

$-1,75-$
$-2,00-$
$-2,00-$
$-6,00-$

- 11. N. Hartz. Bidrag til Danmarks senglaciale Flora og Fauna. $1902 \ldots \ldots \ldots \ldots \ldots \ldots$. . . . .

- 12. N. V. Ussing. Mineralproduktionen i Danmark

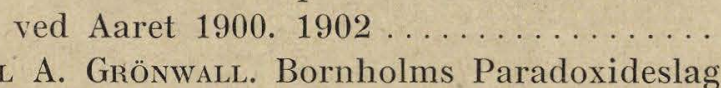
og deres Fauna. $1902 \ldots \ldots \ldots \ldots \ldots \ldots$

- 14. Victor Madsen. Om den glaciale, isdæmmede Sø ved Stenstrup paa Fyn samt om Dannelsen af Teglværksleret i Stenstrup-Egnen. $1903 \ldots \ldots \ldots \ldots \ldots \ldots \ldots \ldots \ldots \ldots \ldots \ldots \ldots \ldots$.

- 15. Karl A. Grönwall. Forsteningsførende Blokke $-2,00-$ fra Langeland, Sydfyn og Erø samt Bemærkninger om de ældre Tertiærdannelser i det baltiske Omraade. $1904 \ldots \ldots \ldots \ldots$. . . 
Nr. 16. N. Steenberg og Poul Harder. Undersøgelser over nogle danske Sandsorters tekniske Anvendelighed. 1905

Pris $0,35 \mathrm{Kr}$.

III. Række.

\section{Populære Fremstillinger.}

Nr. 1. Oversigt over de af Danmarks geologiske Undersøgelse indtil Foraaret 1895 udførte Ar-

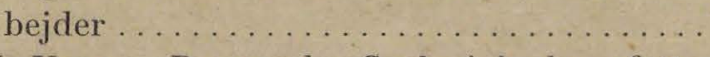

- 2. N. V. Ussing. Danmarks Geologi i almenfatteligt Omrids. Første Udgave 1899. Anden Udgave $1904 \ldots \ldots \ldots \ldots \ldots \ldots \ldots \ldots$. . . . . . .

- 3. V. Mrthmers. Foreløbig Beretning om en geologisk Rejse i det nordøstlige Tyskland og russisk Polen, foretaget i Forsommeren 1901. $1902 \ldots \ldots \ldots \ldots \ldots \ldots \ldots \ldots \ldots \ldots \ldots$. . . . . . .

- 4. V. Milthers. Grundvand og vandførende Lag i Danmark, særlig med Henblik paa For-

syningen af Brønde. $1903 \ldots \ldots \ldots \ldots \ldots .$.
- 5. V. Nordmann. Danmarks Pattedyr i Fortiden. $1905 \ldots \ldots \ldots \ldots \ldots \ldots \ldots \ldots \ldots \ldots \ldots$. . . . . . . . . . . . . . $-4,50-$

- 6. Oversigt over de af Danmarks geologiske Undersøgelse i Aarene 1895-1904 udførte Arbejder, udgivet af Kommissionen for Danmarks geologiske Undersøgelse paa Grundlag af Indberetninger fra Geologerne ... - 1,00 - 